\title{
Will work for food : a behavioural economic analysis of overeating
}

Citation for published version (APA):

Giesen, J. C. A. H. (2010). Will work for food : a behavioural economic analysis of overeating. [Doctoral Thesis, Maastricht University]. Universitaire Pers Maastricht. https://doi.org/10.26481/dis.20101001jg

Document status and date:

Published: 01/01/2010

DOI:

10.26481/dis.20101001jg

Document Version:

Publisher's PDF, also known as Version of record

\section{Please check the document version of this publication:}

- A submitted manuscript is the version of the article upon submission and before peer-review. There can be important differences between the submitted version and the official published version of record.

People interested in the research are advised to contact the author for the final version of the publication, or visit the DOI to the publisher's website.

- The final author version and the galley proof are versions of the publication after peer review.

- The final published version features the final layout of the paper including the volume, issue and page numbers.

Link to publication

\footnotetext{
General rights rights.

- You may freely distribute the URL identifying the publication in the public portal. please follow below link for the End User Agreement:

www.umlib.nl/taverne-license

Take down policy

If you believe that this document breaches copyright please contact us at:

repository@maastrichtuniversity.nl

providing details and we will investigate your claim.
}

Copyright and moral rights for the publications made accessible in the public portal are retained by the authors and/or other copyright owners and it is a condition of accessing publications that users recognise and abide by the legal requirements associated with these

- Users may download and print one copy of any publication from the public portal for the purpose of private study or research.

- You may not further distribute the material or use it for any profit-making activity or commercial gain

If the publication is distributed under the terms of Article $25 \mathrm{fa}$ of the Dutch Copyright Act, indicated by the "Taverne" license above, 
WILL WORK FOR FOOD

A BEHAVIOURAL ECONOMIC ANALYSIS OF OVEREATING 


\section{Colophon}

Graphic design by Janneke Giesen

Production: Datawyse | Universitaire Pers Maastricht

(C) Janneke C.A.H. Giesen, Maastricht 2010

ISBN 978-90-5278-972-9 


\section{WILL WORK FOR FOOD}

\section{A BEHAVIOURAL ECONOMIC ANALYSIS OF OVEREATING}

\section{PROEFSCHRIFT}

ter verkrijging van de graad van doctor aan de Universiteit Maastricht, op gezag van de Rector Magnificus, prof. mr. G.P.M.F. Mols, volgens het besluit van het College van Decanen, in het openbaar te verdedigen op vrijdag I oktober 2ого om I4.0o uur door

Janneke Christina Antonius Hubertina Giesen

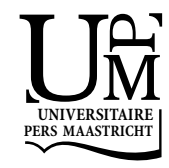




\section{PRomotor}

Prof. dr. A.T.M. Jansen

\section{Copromotor}

Dr. R.C. Havermans

\section{BEOORDELINGSCOMMISSIE}

Prof. dr. H.L.G.J. Merckelbach (voorzitter)

Prof. dr. ir. C. de Graaf (Wageningen UR)

Prof. dr. A.M. Riedl

Prof. dr. D.A. Stapel (Universiteit van Tilburg)

Prof. dr. N.K. de Vries 


\section{Contents}

$\begin{array}{ll}\text { CHAPTER I } & \text { General Introduction }\end{array}$

Part I: Individual differences in the relative reinforcing value of food 2I

ChAPTER 2 Working Harder to Obtain More Snack Foods When Wanting to Eat Less 23

CHAPTER 3 Substituting Snacks with Strawberries and Sudokus: Does Restraint Matter? 35

CHAPTER 4 Will Work for Snack Food: The Association of BMI and Snack Reinforcement 47

Part II: Individual differences in response to public policy measures

CHAPTER 5 Exploring how Calorie Information and Calorie Taxes Influence Lunch Decisions 63

CHAPTER 6 Impulsivity in the Supermarket: Responses to Calorie Taxes and Subsidies 73

$\begin{array}{llr}\text { ChaPTER } 7 & \text { General Discussion } & 89\end{array}$

$\begin{array}{lr}\text { SUMMARY } & 99\end{array}$

$\begin{array}{lr}\text { SAMENVATTING } & \text { IO3 }\end{array}$

$\begin{array}{lr}\text { REFERENCES } & \text { I07 }\end{array}$

$\begin{array}{ll}\text { DANKWOORD/WORD OF THANKS } & \text { II5 }\end{array}$

Curriculum Vitae 

ChAPTER I

\section{General Introduction}




\section{ChAPTER I}

In the past few decades, the number of people being overweight or obese has increased dramatically. An indicator generally used to determine if someone is overweight or obese is the Body Mass Index (BMI). BMI is defined by dividing body weight in kilograms by the square of body height in metres $(\mathrm{kg} / \mathrm{m} 2)$. A BMI equal to or above 25 is regarded as signalling overweight and a BMI equal to or above 30 indicates obesity. In 2006, two-third of the adult population of the United States of America was overweight or obese; $32.8 \%$ had a BMI between 25 and 30, and 33.9\% had a BMI above 30 and was thus obese (World Health Organization, 2006). In the Netherlands, the figures are not that high yet, but they are still alarming. In 2008, 35.7\% of the Dutch adult population reported being overweight and II. $2 \%$ reported to be obese (Centraal Bureau voor de Statistiek, 2009). Thus, nearly half of the Dutch adult population is too heavy and the incidence of overweight/obesity is still rising.

Overweight and obesity can have severe health consequences, such as type 2 diabetes, cardiovascular disease, gallbladder disease, hypertension and several forms of cancer (Field et al., 200I; Must et al., I999; Visscher \& Seidell, 200I). These health consequences also bring along high medical costs (Finkelstein, Ruhm, \& Kosa, 2005). On top of these physical health consequences, research shows that overweight and obese individuals more often express depressive symptoms (Jansen, Havermans, Nederkoorn, \& Roefs, 2008; Scott et al., 2008; Werrij, Mulkens, Hospers, \& Jansen, 2006) and that they are frequently stigmatized (Puhl \& Brownell, 200I). In sum, overweight and obesity are associated with high medical costs, decreased physical health and psychological and social problems. This makes it clear that something needs to be done to stop this epidemic.

Overweight and obesity are the result of a positive energy balance; more energy (i.e., calories) is consumed than expended. To a large degree, this positive energy balance can be ascribed to excessive food intake or in other words overeating (Jéquier, 2002; Swinburn et al., 2009). A contributing factor on why currently so many people exhibit the tendency to overeat is the obesogenic environment. This environment promotes sedentary behaviour and more importantly offers an increasingly wide variety of cheap, aggressively marketed high-calorie foods.

Food is a primary reinforcer; that is, food rewards strengthen any behaviour that leads to it (Epstein \& Leddy, 2006). The basis for this reinforcing property of food is plain: survival requires energy and food provides this energy in the form of calories made available by macronutrients (viz., carbohydrates, proteins, fats and alcohol). Although it was once useful to pursue and consume as many calories as possible, this innate drive has become redundant and even detrimental in the current environment where food is omnipresent. The industrialization of food supply and the corresponding increase in available foods and decrease in food costs started over the last two centuries and accelerated over the last few decades (Tillotson, 2004). From the I970s, new technologies and agricultural subsidies enabled the 


\section{GENERAL INTRODUCTION}

introduction of more varied and incrementally cheaper high-energy dense foods to the food market (James, 2008; Tillotson, 2004). Around the same time, the incidence of obesity steadily raised to its current epidemic proportions.

The environment clearly has a substantial impact on excessive food consumption. Still, not every person becomes overweight or obese in the 'land of plenty'. Some people seem to be more vulnerable than others to overeating, that is, the overconsumption of highenergy dense foods. It appears as if some people are more sensitive than others to the rewarding, motivational appeal of high-caloric foods. In other words, high-energy dense foods might have a higher reinforcing value for these individuals.

The present thesis concerns a behavioural economic analysis of individual differences in the relative reinforcing value of high-energy dense foods (Part I) and individual differences in response to policy measures aimed at changing the food environment (Part II).

\section{INDIVIDUAL DIFFERENCES IN OVEREATING}

Restrained eaters defined by the restraint scale (Herman \& Polivy, 1980) are persons who are concerned about their body weight and shape and therefore try to restrict their food intake. However, it must be noted that they are not always successful in their dieting attempts. These so-called 'restrained eaters' form a group of people vulnerable to overeating. They have been found to overeat in several conditions, for example when restrained eaters first consumed a high caloric preload (milkshake), they subsequently ate more ice cream on a taste test than without this preload. Unrestrained eaters conversely ate less icecream following the preload (Herman \& Mack, 1975). In another study, smelling a high caloric food triggered restrained eaters to eat more on a taste test compared to without smelling the food (Jansen \& van den Hout, 199I). Similar patterns have been found when instead of a preload, negative affect or anxiety was induced in restrained eaters prior to a taste test (Polivy, Herman, \& McFarlane, I994; Schotte, Cools, \& McNally, I990). These studies all demonstrate that restrained eaters are prone to overeat, but the question why restrained eaters show this disinhibited eating is still largely unresolved.

Overweight and obese individuals form another group of people with a tendency to overeat on specifically high-energy dense foods (Drewnowski, 1996). Research has shown that in general both restrained eaters and overweight/obese individuals are more impulsive compared to unrestrained eaters and normal weight individuals (Nederkoorn, Braet, Van Eijs, Tanghe, \& Jansen, 2006; Nederkoorn, Smulders, Havermans, Roefs, \& Jansen, 2006; Nederkoorn, Van Eijs, \& Jansen, 2004). So when tempted with food, it will be more difficult 


\section{ChAPTER I}

for these individuals to resist the food. But why are especially high-energy dense foods so tempting? Why do restrained eaters and overweight/obese individuals overeat on specifically high-energy dense foods? In the current thesis it is hypothesized that the relative reinforcing value of these high-energy dense foods is higher for individuals vulnerable to overeating compared to individuals without such vulnerability.

\section{THE RELATIVE REINFORCING VALUE OF FOOD AND BEHAVIOURAL ECONOMICS}

Thorndike's Law of Effect states:

"Of several responses made to the same situation, those which are accompanied or closely followed by satisfaction to the animal will, other things being equal, be more firmly connected with the situation, so that, when it recurs, they will be more likely to recur; those which are accompanied or closely followed by discomfort to the animal will, other things being equal, have their connections with that situation weakened, so that, when it recurs, they will be less likely to occur" (Thorndike, I9II, p. 244).

In other words, when behaviour is reinforced, the likelihood that the behaviour will be repeated increases, whereas if the result of the behaviour is experienced as aversive (or discomforting or annoying), it becomes less likely that the behaviour will recur. For example, when a child sees a piece of chocolate and puts it in his mouth, the sweet taste and the obtained energy are experienced as pleasant and hence reinforcing. Therefore, the next time the child sees chocolate, he will most likely eat it. However, if it was not chocolate but Brussels sprouts he put in his mouth, then the bitter taste and low energy density of the sprouts probably would be experienced as unpleasant. The next time the child would encounter a meal with Brussels sprouts he would most likely refrain from eating it. This all seems very straightforward; chocolate is more reinforcing than Brussels sprouts are. But what if there are two foods that both seem to be reinforcing. How can one determine then which food is relatively more reinforcing? Indeed, how does one determine the relative reinforcing value of food?

Skinner showed that a hungry rat in a free operant chamber (also known as Skinner box) would press a lever faster to obtain food reward compared to when the rat was sated (Skinner, 1938). From this finding Skinner concluded that "reflex strength" (the correlation 
or association between the food reward and antecedent response) could be assessed by measuring response rate. This is an important notion, though not entirely true. Response rate itself can be influenced by reinforcement, for instance when not every lever press results in food reward, but only once in every 20 seconds, an animal will demonstrate a slow rate of responding matching the 20 seconds interval reinforcement schedule (see also Ferster \& Skinner, 1957; Hursh \& Silberberg, 2008). Directly after the reinforcement the animal typically stops performing the operant response only to resume responding just before a certain interval (in this example an interval of $20 \mathrm{sec}$ ) ends. It is as if the animal not only has learned that a certain response renders food reward but also that this relation merely holds every 20 seconds.

Herrnstein (1970) elaborated the notion that response rate and reinforcement are related, when describing choice behaviour. One might argue that every operant response reflects at least a choice between showing a given response, or not. Mostly, a choice is made between two or more behavioural options: "should I study for my exams, or go out and party?" The matching law (Herrnstein, I970) describes the distribution of choice allocation for a given sequence of choices by proposing that the rate of operant responding is relative to the rate of reinforcement. This matching law is reflected by the following formula:

$$
\frac{P_{L}}{\left(P_{L}+P_{R}\right)}=\frac{R_{L}}{\left(R_{L}+R_{R}\right)},
$$

$\mathrm{P}$ denotes the number of responses (i.e. pecks at a response key as Herrnstein used pigeons for subjects) and $\mathrm{R}$ stands for the number of reinforcements. The subscripts represent two response alternatives: Left response key (L) and Right response key (R). 


\section{ChApter I}

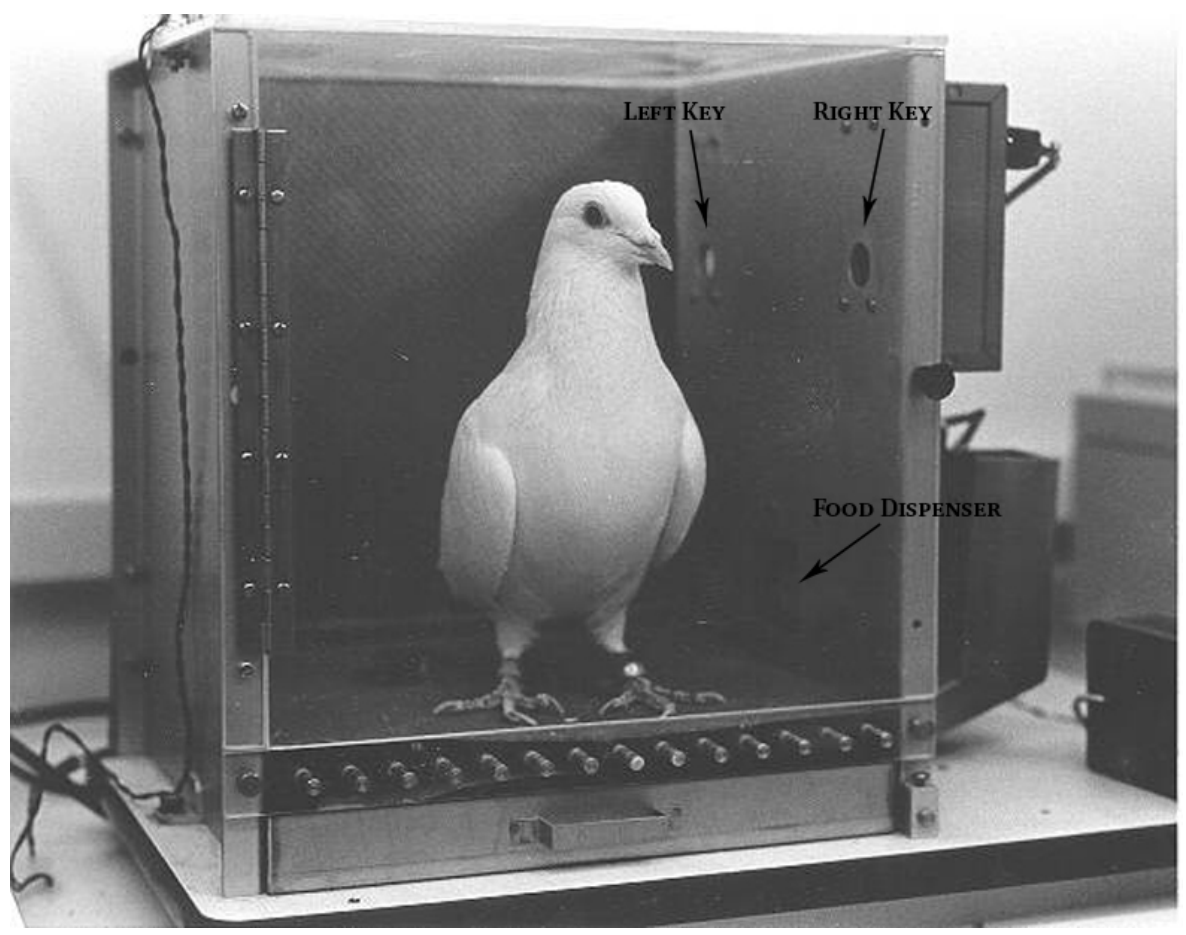

Figure I.I. A pigeon in an operant chamber (Skinner Box), with two keys for reinforcement (Left and Right).

To illustrate matching, imagine being a pigeon stuck in a Skinner box having two response keys to peck on. Both keys offer the same food as reinforcement, but the concurrent interval schedules of reinforcement differ per key. The left key delivers food for a key peck on every 60 seconds (a so termed fixed interval [FI] reinforcement schedule of $60 \mathrm{sec}$ ), whereas the right key returns food for a key peck every 20 seconds (a fixed interval [FI] reinforcement schedule of $20 \mathrm{sec}$ ). This means that in a single hour, 60 reinforcements (food deliveries) for pecks on the left key are possible, and I8o for pecks on the right key. In terms of the matching law, then, $R_{L} /\left(R_{L}+R_{R}\right)=60 / 240=.25(1 / 4)$. Thus, $P_{L} /\left(P_{L}+P_{R}\right)=$ $1 / 4$, this equation can be reduced to $P_{L}+P_{R}=4 P_{L}$, which results in $I_{R}=3 P_{L}$, and consequently the following proportion is found: $\mathrm{I} / 3=\mathrm{P}_{\mathrm{L}} / \mathrm{P}_{\mathrm{R}}$. The matching law thus predicts that 


\section{GENERAL INTRODUCTION}

$1 / 4$ of the pecks will go to the left key and $3 / 4$ of the pecks will be directed to the right key, in other words, for every peck on the left, there are three pecks on the right. This relative response distribution is exactly what has been found under these conditions (Herrnstein, I96I).

It is important to note that matching is not expected if the preference for the two reinforcers differ from each other. If the left key in the aforementioned example would provide the pigeon equivalent for chocolate and the right key would provide the pigeon equivalent for sprouts, then the pigeon would quickly come to peck exclusively at the left key. Herrnstein (1970) however, did mention the following:

"It should, however, be possible to scale reinforcers against each other or responses against each other by assuming that the subject must be conforming to the matching relation whenever it is in a choice situation of the general type employed in these experiments, and by adjusting the measures of response or reinforcement accordingly" (Herrnstein, 1970, p. 249).

To be concrete, the matching law predicts that when two equally preferred reinforcers are offered at the same time (concurrently) at the same reinforcement interval (i.e. every Io seconds) the responses will be $50 \%$ on the left key and $50 \%$ on the right key. However, if the two reinforcers are not equally preferred, the proportion responses on the left will be different from the proportion on the right. For instance if the reinforcer on the left key was chocolate and the reinforcer on the right key was pineapple and $75 \%$ of the responses were left and $25 \%$ of the responses were right, then it can be said that chocolate is three times more reinforcing than pineapple. Note, that generally one would not know that the two reinforcers are differently preferred. This method thus provides a way to determine if foods are preferred differently and if so to what exact proportion.

A variation on this type of choice task used by Herrnstein is a concurrent schedules task where reinforcement is not dependent upon responding on time interval schedules, but on response frequency (i.e. reinforcement after every Io responses or every 20 responses et cetera). With such a task it is possible to assess the relative reinforcing value of a reinforcer. For example, if the reinforcers are again chocolate and pineapple, and the response requirement is 2 for both reinforcers (i.e., two responses per reinforcer) then it is expected that the participant will respond for chocolate (when assuming that the chocolate is more reinforcing). Now by gradually increasing the response requirement for chocolate (from 2 responses to 4, to 8 and so on) while maintaining the original response requirement of 2 responses for pineapple reinforcement one can determine at which point a participant gives up working for chocolate. Thus it is possible to determine how much effort one is prepared to invest in chocolate relative to pineapple (e.g., Hursh, 1987; Vuchinich \& Tucker, I983). 


\section{CHAPTER I}

When considering working for reinforcers in a concurrent schedules task, one can make the analogy with economics. The amount of work necessary for obtaining a reinforcer are costs one makes, or the price one pays for that reinforcer. It is not surprising that Kagel and Winkler (1972) referred to "behavioural economics" when discussing concurrent schedules tasks. If one increases the price of a reinforcer (i.e. the amount of work necessary to obtain the reinforcer), the chances are that the demand for that reinforcer decreases. In behavioural economics this relation between price and demand is illustrated with a demand curve (see Figure I.2). In such a demand curve the change in consumption or demand of a reinforcer is plotted against its unit price. The unit price is simply the price of one unit or a certain amount of the reinforcer. For example, if a bag of candies costs 2 euro's and the price increases to 4 euro's, but the content of the bag is also doubled then the unit price stays the same.

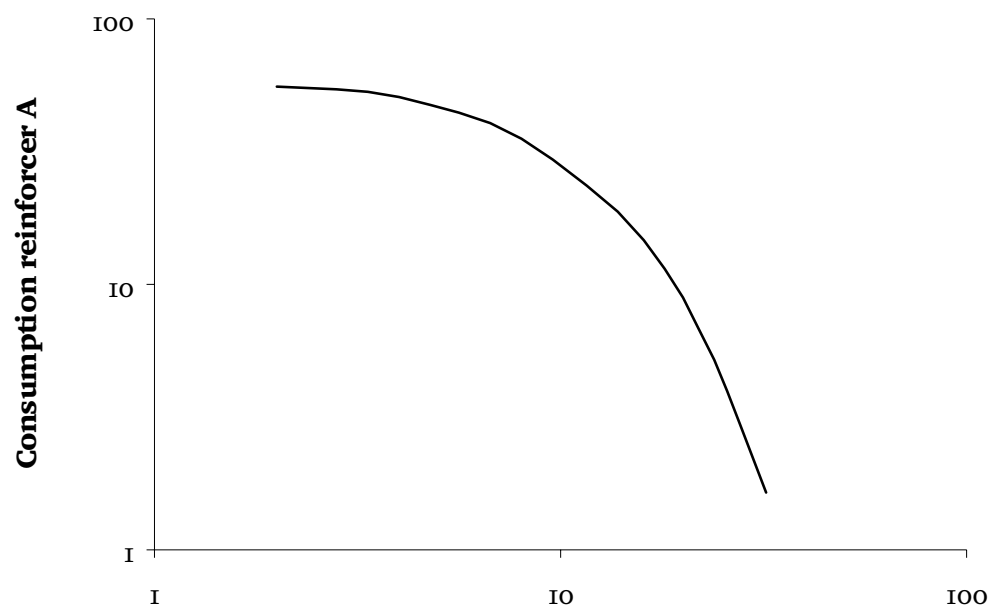

\section{Unit Price reinforcer A}

Figure I.2. A hypothetical demand curve with an increase in unit price resulting in a decrease in consumption of reinforcer A. 


\section{GENERAL INTRODUCTION}

The change in demand or consumption relative to the change in unit price is known as demand elasticity. If the unit price of a bag of candies increases, but the demand hardly decreases, then it is said that the demand for candies is inelastic. However, when the price increases as much as that the demand decreases proportionally or even disproportionately, then it is said that the demand for that reinforcer (or product) is elastic.

Luxury goods (e.g. television, a micro-wave oven, an iPad, et cetera) are typical examples of reinforcers with an elastic demand; this is because these are products not essential for one's daily survival (or even well-being) and one could thus (easily) do without. On the other hand, daily necessities are often inelastic. Examples of such products are salt, water and staple foods such as bread, rice and potatoes. This would imply that consumption of hedonic goods (e.g., snack foods, cigarettes and alcohol) could be easily altered by increasing the corresponding costs. However, a rat study showed that demand for alcohol was inelastic (Heyman, Keith, \& Jason, 1999). It is suggested that the somewhat addictive aspect of alcohol accounts for the inelasticity. Note however, that it does not mean that the demand for alcohol will be inelastic for everybody. Not everyone is addicted to alcohol. The rats used in this experiment were trained to drink alcohol before the experiment. It is conceivable that rats not trained to consume alcohol would stop working for alcohol or start working for an alternative reinforcer such as food. Food then would serve as a substitute for alcohol.

If the price of one reinforcer increases and the demand for this reinforcer decreases it is possible that the demand for another reinforcer (in general with similar features) will increase; this reinforcer then serves as a substitute for the other. In most cases a small price increase for one reinforcer will not result in a switch to another reinforcer. Often the price increase has to be sufficiently substantial to initiate such switch. In that case we speak of an imperfect substitute. This is often the case when one reinforcer is not as appealing as the other (see for example Lappalainen \& Epstein, 1990).

Individual differences also play a role in whether or not something is a good substitute. A study by Goldfield and Epstein (2002) investigating the reinforcing value of snack foods showed that for normal weight participants fruit and vegetables were relatively good substitutes for snacks, when the costs for snacks increased. Whether this is also true for overweight people or people with a tendency to overeat is still unknown. In a study by Saelens and Epstein (I996) obese women and normal weight women performed a concurrent schedules task in which they could work for high-calorie snacks (i.e., chocolate bars, ice

- Apart from substitution, a product or reinforcer can serve as a complement to another reinforcer. In that case, a price increase of one reinforcer will decrease demand for both. Think of mayonnaise as the complement for French fries. For an extensive review see Madden (2000). 


\section{ChAPTER I}

cream, cookies or cake) or for minutes spending on a sedentary activity (i.e., reading a magazine, playing a computer game or watching a comedy). In the beginning the response requirements (or reinforcement schedules) for earning points for snacks and sedentary activities were identical, but as the task continued the response requirement for snack points increased. In other words, the price for snacks increased, because participants had to put more effort into obtaining snack points. The results showed that obese women chose to work for snacks more often than normal weight women and also worked harder for snacks, compared to normal weight women. From this experiment it can be concluded that food has a higher relative reinforcing value for obese women than for normal weight women. Note, however, that it cannot be concluded that high-calorie foods have a higher reinforcing value for obese women, because no low-calorie foods were offered as alternative option. Sedentary activities turned out to be better substitutes for snacks for normal weight women than for obese women. Therefore, Epstein and Saelens pointed out that still many questions remain to be answered. One such question is: "Are there individual differences . . . in the relative reinforcing value of certain food items or eating in general?" (Epstein \& Saelens, 2000, p. 304). This particular question is further explored in chapters 2, 3 and 4.

\section{Public POLICY AND BEHAVIOURAL ECONOMICS}

An obvious solution to the obesity problem would be to exercise more and to eat less, with the focus on eating less high-energy dense foods. But this is easier said than done. It requires a considerable degree of self-control to stick to a diet and not being tempted by all the readily available palatable foods. Dieting and weight-loss programs aiming at behaviour change on an individual level are usually effective at achieving considerable weight loss on the short term. However, on a longer term they do not seem to be very successful; that is, most participants regain weight, some of them eventually weigh more than before their participation in the weight loss program (Lowe et al., 2006; Sarwer \& Wadden, I999; Stice, Cameron, Killen, Hayward, \& Taylor, 1999).

Given that overweight/obesity is such a widespread problem and individual self control seems to be no match for persistent environmentally induced urges to indulge oneself, public policy measures aiming at decreasing calorie intake are warranted. Possible public policy measures could comprise informing the people about the foods they consume, for instance by means of calorie labelling. This form of public policy has already been implemented in New York City. Research shows that consumers considerably underestimate the amount of calories for especially high-calorie foods (Burton, Creyer, Kees, \& Huggins, 


\section{GENERAL INTRODUCTION}

2006). Thus, calorie labelling might facilitate healthier (i.e. less energy dense) food choices. However, notwithstanding the popularity of this measure among New York City policy makers, Harnack and French (2008) revealed that the few studies examining calorie labelling only report weak and inconsistent effects on (intended) food choice. One study found no effects of calorie labelling on food choice, five studies found some support that calorie labelling might reduce the number of calories chosen for a meal. However, the magnitude of these effects was small and some of these studies found inconsistent effects. For example, in one study participants ordered a dinner from a menu. After this order was recorded they were given the menu again but this time with calorie information and subsequently they were asked if they wanted to change their meal choice. Only a minority of the participants (approximately 20\%) decided to change their order.

Another possibility for public policy involves changing the food environment, such as making high-calorie foods less attractive and low-calorie foods more attractive. According to behavioural economic theory this could be accomplished by changing the prices of the foods in order to affect the demand for these foods; high-energy dense foods would increase in price and low-energy dense foods would decrease in price. Research on the effects of such a price increase of high-energy dense foods, or in other words a calorie tax, is rare, but the few experimental studies addressing this issue to date indicate that it is beneficial in decreasing calorie consumption (e.g., Epstein, Dearing, Roba, \& Finkelstein, 2010; Epstein et al., 2006). With respect to subsidies on healthy foods or low-energy dense foods, experimental research suggests that it could help increase the amount of healthy products consumed (e.g., Epstein et al., 20Io; French et al., 20oI). However, one could wonder whether that is ideal? An increase in the consumption of healthy or low-energy dense foods may also result in an increase in calories consumed, e.g. if the low-energy dense product does not substitute a high-energy dense product. Likewise, the money that is saved on the low-energy dense foods might be subsequently spent on high-energy dense foods (Epstein et al., 2010).

Research on these behavioural economic interventions is still limited, especially research focusing on whether and how pricing strategies (e.g., taxing high-energy dense foods) may actually interact with individual differences in economic variables, such as income, but also with psychological variables, such as dietary restraint and impulsivity. Do these policies target the people who need it the most: the overweight and the obese and those who exhibit the tendency to overeat? The role of individual differences on the effect of public policy measures aimed at reducing calorie consumption is investigated in chapters 5 and 6. 


\section{Chapter I}

\section{OUTLINE OF THE PRESENT THESIS}

The present thesis comprises a series of studies concerning individual differences in the relative reinforcing value of high-energy dense foods (Part I). More specifically, in chapter 2 it is investigated whether the relative reinforcing value of snack foods is higher in restrained eaters who are not currently dieting to lose weight compared to unrestrained eaters and current dieters. This was tested by means of a concurrent schedules task, where participants could work for points for their highest rated snack food and highest rated fruit or vegetables. By gradually increasing the response requirement for the snack food, differences between groups in relative reinforcing value for snacks could be determined.

In chapter 3, it is investigated whether fruit/vegetables are better substitutes for snacks than sedentary activities are, and if so, whether dietary restraint plays a role in how snacks are being substituted. To examine these questions, a choice task with three concurrent schedules was developed. Again, the response requirement for snacks was gradually increased in order to assess substitution.

Chapter 4 concerns differences in the relative reinforcing value of snack foods between normal weight and overweight/obese individuals. It is hypothesized that overweight/obese individuals find snack foods more rewarding, and thus will exert more effort to obtain snacks on a concurrent schedules task.

The second part (Part II) of this thesis focuses on individual differences in response to policy measures aimed at decreasing energy consumption. In chapter 5 , the effects of two policy measures (i.e., calorie labelling and a calorie tax) on the number of calories chosen for lunch were explored. Furthermore, it was investigated how these measures differentially affect high and low restrained eaters. It is hypothesized that a calorie tax would reduce the number of calories chosen for lunch and that the calorie labelling would only encourage the high-restrained eaters to reduce calorie consumption.

In chapter 6, it was tested if taxing high-energy dense foods and subsidizing lowenergy dense foods influences the number of calories bought for groceries in an internet supermarket. Moreover, It was tested whether this tax and subsidy differentially influences high and low impulsive individuals. It was hypothesized that high impulsive participants relative to less impulsive participants would be more sensitive to the hedonic appeal of highenergy dense foods and less to the costs or price associated with these foods, implying that impulsive people's food choice and food purchase would be relatively impervious to a pricing policy. 
GENERAL INTRODUCTION

In chapter 7 an overview of the main findings of each of the studies in this thesis is presented and these findings are discussed in terms of their theoretical and societal relevance. Further, suggestions for future research endeavours are provided. 



\section{PART I}

INDIVIDUAL DIFFERENCES IN THE RELATIVE REINFORCING VALUE OF FOOD 



\section{ChAPTer 2}

\section{Working Harder to Obtain More Snack Foods When Wanting to Eat Less}

This chapter is an adapted version of: Giesen, J. C. A. H., Havermans, R. C., Nederkoorn, C., Strafaci, S., \& Jansen, A. (2009). Working harder to obtain more snack foods when wanting to eat less. Behaviour Research and Therapy, 47, I3-17. 


\title{
CHAPTER 2
}

\begin{abstract}
This study investigates individual differences in the reinforcing value of snack food. More specifically, it was investigated whether differences in restraint status are associated with differences in working for high-caloric snack food. Thirty-six unrestrained non-dieters, twenty restrained non-dieters and fifteen current dieters performed a concurrent schedules task in which they had the option to work for points for either snack food or fruit and vegetables. By progressively increasing the "price" of the snack foods (i.e., the amount of work required to obtain extra snack points) the relative reinforcing value of snack food was determined. As hypothesized, restrained non-dieters worked harder and current dieters worked less hard to obtain snack food as compared to unrestrained non-dieters.
\end{abstract}




\section{SNACK REINFORCEMENT IN RESTRAINED EATING}

World wide, the incidence of overweight and obesity is increasing and this is problematic as especially obesity can have grave consequences for one's health. Overweight is the result of a positive energy balance, meaning that more energy is consumed than expended. As a low level of physical activity is less likely to account for excessive weight gain, food intake can be considered as the most important determinant of changes in energy homeostasis (Jéquier, 2002). According to this line of reasoning, obesity is mainly the result of overeating (i.e. excessive caloric intake). Why some people tend to overeat is still unclear, though a specific group of people at risk for developing overweight and obesity have been found to be people with high self-reported dietary restraint. In the short term, dieting leads to weight loss, but somewhat paradoxically, on a longer term dietary restraint actually predicts weight gain (Drapeau, Provencher, Lemieux, \& Despres, 2003; Klesges, Isbell, \& Klesges, I992; Lowe et al., 2006; Stice et al., 1999; Stice, Presnell, Shaw, \& Rohde, 2005).

Restrained eaters are concerned about their body weight and shape and therefore try to restrict their food intake. However, as dietary restraint appears to predict long term weight gain, it is clear that restrained eaters are not particularly successful at their weight control attempts (Heatherton, Herman, Polivy, King, \& McGree, 1988). Indeed, restrained eaters have been found to overeat after a high caloric preload. In their seminal study, Herman and Mack (1975) presented their participants with no, one or two milkshakes as a preload. After consuming the preloads, participants had to taste three different flavours of ice-cream. The amount of ice-cream consumed was measured. Participants scoring low on restraint consumed less ice-cream as the preload increased, whereas the high restrained participants consumed more ice-cream following the preload than without the preload. Whether the preload consisted of one or two milkshakes did not make a difference in the amount of ice-cream consumed by the high restrained participants. The finding of overeating after a preload has been called counter-regulation. One explanation for this counterregulation is that restrained eaters consider their diet to be broken after the consumption of a high caloric preload and this triggers disinhibited eating in the restrained eater (Herman \& Mack, 1975; Polivy, 1976). Such disinhibitive cognitions are, however, not a prerequisite for triggering disinhibited eating. Jansen and Van den Hout (I99I), for example, demonstrated counter-regulation in restrained eaters after merely smelling a preload. In this case, the thought of breaking a diet could not have been the reason for overeating since the participants did not consume the preload. Further, a study by Urbszat, Herman, and Polivy (2002) showed that restrained eaters also demonstrate disinhibited eating when anticipating to go on a diet the next day. Negative affect and anxiety have also been found to trigger overeating in restrained eaters. Restrained eaters who were shown a frightening film ate more food during a taste test than restrained eaters who saw an emotionally neutral film did. Unrestrained eaters' eating behavior was unaffected by the manipulation (Schotte, et al., I990; see also, Polivy, et al., 1994). Restrained eaters thus seem to be triggered to overeat in 


\section{ChAPTER 2}

various situations and by different cues. However, there are a few studies that failed to demonstrate consistent disinhibition in restrained eaters. This equivocal finding can be attributed to the fact that typically restrained eaters express body, weight, and shape concerns and the desire to lose weight but are not necessarily dieting (Lowe, 1993). Indeed, the restrained eaters that do diet (the so called current dieters; CDs), do not show disinhibition; that is, in a laboratory setting they do not show counter-regulation after the consumption of a preload (Lowe, I995; Lowe, Whitlow, \& Bellwoar, I99I). According to the three factor model of dieting (Lowe, 1993), CDs can successfully regulate their caloric intake at least temporarily and therefore, one should distinguish CDs from restrained non-dieters (RNDs).

A potential reason for RNDs' tendency to disinhibit may simply be that particularly high caloric foods are relatively more reinforcing for them than they are for unrestrained eaters (unrestrained non-dieters; UNDs). These foods have a stronger motivational appeal for RNDs than they have for UNDs. However, note that the reinforcing value of food is always a relative value and not an absolute value. When given the choice between performing a task to obtain a high-calorie or low-calorie snack, one may choose to work for the highcalorie snack indicating that the high-calorie snack is more reinforcing than the low-calorie snack. But when the choice is between a high-calorie snack and a certain amount of money, the same person might choose money over the snack. Because the reinforcing value of food is relative, preference for a low-calorie snack can be interpreted as reflecting approach towards the low-calorie snack, but also as avoidance of the high-calorie snack. This may also explain why CDs do not always demonstrate disinhibited eating as the consumption of highcalorie foods directly interferes with their diet (and the express wish to lose weight). According to this line of reasoning, the momentary relative reinforcing value of high-calorie food should be stronger for RNDs but weaker for CDs as compared with UNDs.

In this experiment it was investigated whether the relative reinforcing value of snack food differs between RNDs, CDs and UNDs as outlined above. This relative reinforcing value of snack food is assessed by means of a concurrent schedules task that measures how hard a participant works for snack food, compared to an alternative, in this case low caloric food (see e.g., Goldfield \& Epstein, 2002). A participant is offered the choice between working for points for snacks and points for low caloric food. In the beginning the response requirement for earning points for both foods are equal. However, as the task continues the response requirement for earning snack points increases whereas the response requirement for the low caloric food points remains the same. The more effort a person makes in earning snack points the higher the relative reinforcing value of snack food. Individual differences in the relative reinforcing value of food have already been observed using a similar task. Saelens and Epstein (1996) found that obese women are more inclined to work for palatable foods 
as compared to non-obese women. From these results, they concluded that food is more reinforcing for obese women than for non-obese women.

To recapitulate, we hypothesized that RNDs invest more effort in obtaining snack food than UNDs. Additionally we hypothesized that CDs will not show as much effort in working for snack food compared to RNDs and UNDs.

\section{METHOD}

\section{Participants}

Participants were female introductory psychology and health science students from Maastricht University in the Netherlands. Students were selected based on their scores on three items of the Restraint Scale (RS; Herman \& Polivy, I980), concerning diet frequency, the influence of a weight fluctuation on their way of life, and feelings of guilt after eating. A pilot study among female undergraduate students $(n=767)$ concerning the validation of selecting participants based on their scores on these three items of the RS revealed that the score on the three items highly correlates with the total score on the complete RS, $r=.84, p$ $<$.or. Scores on the complete Restraint Scale range from o to 35. The maximum score to be obtained from these three items chosen from the Restraint Scale is io. A participant scoring 3 or below on these three items classified as an unrestrained eater, whereas a participant scoring 5 or above was classified as a restrained eater. These cut-offs were chosen as the pilot data indicated that a score of 3 or below on these three items corresponded with a total mean RS score of 7.5, and that the three-item score of 5 and above corresponded with a total mean RS score of 16.4 .

At the end of the actual test session, participants were asked whether they were currently dieting to lose weight, which could simply be answered with a "yes" or "no" (see also Lowe \& Timko, 2004). On the basis of these data, three groups were formed: the UNDs $(n=$ $36)$, the RNDs $(n=20)$ and the CDs $(n=15)$. All I5 CDs initially classified as restrained eater. Data from four extra participants were excluded from the analysis. Three of them did not grade at least one of the snack foods or fruits and vegetables as sufficiently palatable. One participant misinterpreted the instructions for the experiment. Participant characteristics of the three groups are shown in Table 2.I. Participants were given one course credit or a $€ 7.50$ monetary voucher for participating in the study. This study was approved by the ethical committee of the Faculty of Psychology. 


\section{ChAPTER 2}

Table 2.I

Means with Standard Errors and F-test of group characteristics ${ }^{\mathrm{a}}$

\begin{tabular}{|c|c|c|c|c|c|c|c|}
\hline \multirow[b]{2}{*}{ Variable } & \multicolumn{2}{|c|}{$\begin{array}{c}\text { UNDs } \\
(N=36)\end{array}$} & \multicolumn{2}{|c|}{$\begin{array}{c}\text { RNDs } \\
(N=20)\end{array}$} & \multicolumn{2}{|c|}{$\begin{array}{c}\text { CDs } \\
(N=15)\end{array}$} & \multirow[b]{2}{*}{$F(2,68)$} \\
\hline & $M$ & $S E$ & $M$ & $S E$ & $M$ & $S E$ & \\
\hline Age (years) & 18.9 a & 0.2 & $19.1_{\mathrm{a}}$ & 0.4 & $19.1_{\mathrm{a}}$ & 0.4 & 0.23 \\
\hline 3 items RS & $1.4_{\mathrm{a}}$ & 0.2 & $6.3_{\mathrm{b}}$ & 0.3 & $6.3_{\mathrm{b}}$ & 0.4 & 144.37 \\
\hline BMI (Body Mass Index; kg/m²) & $20.3_{\mathrm{a}}$ & 0.4 & $23.1_{\mathrm{b}}$ & 0.6 & $25.5_{\mathrm{c}}$ & 1.0 & 18.10 \\
\hline Hunger (100 mm VAS) & $54.9 \mathrm{a}$ & 3.5 & 51.6 & 4.2 & $49.1_{\mathrm{a}}$ & 5.1 & 0.48 \\
\hline Hedonics for most liked snack food (0-10) & $8.5_{\mathrm{a}}$ & 0.2 & $8.5_{\mathrm{a}}$ & 0.3 & $8.4_{\mathrm{a}}$ & 0.3 & 0.04 \\
\hline Hedonics for most liked fruit or vegetable (0-10) & $8.6_{\mathrm{a}}$ & 0.2 & $8.6_{\mathrm{a}}$ & 0.2 & $8.9_{\mathrm{a}}$ & 0.4 & 0.42 \\
\hline
\end{tabular}

${ }^{\mathrm{a}}$ Means with different subscripts are significantly different from each other, $\mathrm{p}<0.05$ (one-tailed).

\section{Procedure and Materials}

When invited for the experiment, participants were asked to eat something two hours before the experiment and from that time on not to eat until their participation. Participants were told that the experiment was about choice behaviour and mental fatigue. All participants were tested individually between noon and 6 PM. Once in the lab, participants were presented with bite-size portions of eight different food items. Taking into account that people have different taste preferences, participants were provided with four items from the category 'fruit and vegetables' (cucumber $[ \pm 4 \mathrm{~g}$.], tangerines [ $\pm 5 \mathrm{~g}$.], white grapes $[ \pm 6$ g.], and canned pineapple chunks [ \pm 6 g.] [Del Monte Foods, San Francisco]) and four items from the category 'snack food' (chocolate M\&M's [ \pm 3 g.] [Masterfoods, Veghel], chocolate chip cookies [ \pm 3 g.] [Van Welzen, Smilde Bakery, Edam], sweet pepper flavored chips [ \pm 2 g.] [Lay's, Smiths Food Group, Utrecht] and cocktail snacks [ \pm 2 g.] [Duyvis Productions, Zaandam]). These eight bite-size portions together contained approximately $55 \mathrm{kcal}$. The eight foods were presented in random order for a paper-and-pencil rating task. Participants were asked to taste (and consume) the foods and subsequently rate its momentary palatability (II-points scale: o "not at all palatable at the moment" to Io "highly palatable at the moment"). This rating task was followed by a ranking task, where the participant was asked to rank the eight food items from most palatable at this moment to least palatable at this moment. Because level of hunger may possibly influence the reinforcing value of food (Lappalainen \& Epstein, 1990), participants were asked to indicate how hungry they were at that moment on a roo mm Visual Analog Scale (VAS; o "not at all hungry" to Ioo "very hungry") to be able to check whether the groups did not differ on initial hunger. Next, the participants were presented with a filler-questionnaire concerning choice behaviour. This allowed the experimenter time to enter the highest rated snack and the highest rated fruit or 


\section{SNACK REINFORCEMENT IN RESTRAINED EATING}

vegetable as choice options for the concurrent schedules task into the computer program. Subsequently, participants completed the concurrent schedules task.

Participants were told that they were going to play a computer game in which they had to earn points for food and that the computer would randomly select two of the eight food items they had just evaluated as their choice options. In fact they were always offered their highest rated snack and their highest rated fruit or vegetable as choice options in the task. Participants were informed that as the game proceeded it would get harder, however not impossible to earn points for one of the two options. Participants were explained that every ten points equals ten grams of the matching food and that they would have to eat the food that was earned after the game. This instruction served to limit the probability of socially desirable responding by the participant during the task. Points for the different food items could be earned by means of pushing the related key; that is, a left response key corresponding with the high-caloric snack, or a right response key corresponding with the low-caloric alternative (for half of the participants this response key assignment was reversed).

The game consisted of five trials. In every trial 20 points in total (snack points + fruit/vegetable points) had to be earned. Each trial comprised of making a series of choices. For each choice, a picture of the high-calorie snack and fruit/vegetable alternative was presented on screen and the participant was instructed to press the key corresponding to either one of the food options. Immediately after the key press, participants would receive feedback indicating whether they had earned a point for the food item, or not. In the first trial the reinforcement schedules for snacks and fruit or vegetables were both at FR2 (Fixed Ratio of 2), meaning that after every two responses on the same key a point was earned for the corresponding food. This FR2 reinforcement schedule remained the same for the fruit and vegetable option throughout the task. However, the reinforcement schedule for the high-caloric snack option changed with every trial, from FR2 in the first trial to FR4, FR8, FRI6 and FR32 in the fifth and last trial. This means that in the last trial a participant would have to push 32 times on one and the same response key to earn one point for snacks and that if the participant decided to work entirely for snack points in the last trial, she would have to push 640 times on the same response key.

After performing the computer game, when having earned a total of roo food points (snack + fruit/vegetable points), participants exchanged the points they had earned for the foods and ate it accordingly. Note that each participant thus had to consume a total of $100 \mathrm{~g}$ of food. When having finished eating the foods, participants received a second task: a reaction time (RT) task. In this task, participants simply had to press a response key as fast as possible whenever the letter $\mathrm{X}$ appeared on screen. This task had a 5 min duration and served as a filler task in line with the cover story that this study measures the potential effect of making choices on mental ability. 


\section{ChAPTER 2}

After the RT task, participants were asked whether they were currently dieting to lose weight and at the end of the test session, height and weight were measured to calculate Body Mass Index (BMI; kg/m²).

\section{Design and Analysis}

The dependent variable is the number of responses for snack food in each trial on the concurrent schedule task. Because the number of points to earn per trial was fixed (i.e. 20 points), the number of responses for fruit and vegetables are not of interest here as they are directly related to the number of responses for snacks. Number of responses for snack food were analyzed in a 5 (trial: FR2, FR4, FR8, FRI6, FR32) $\times 3$ (group: UNDs, RNDs, and CDs) mixed repeated measures analysis of variance (ANOVA), with trial as within subject factor and group as between subjects factor. Since we were interested in differences in responses between groups, three subsequent mixed repeated measures analyses were planned with each time two levels of the between-subject factor 'group': RNDs versus UNDs, RNDs versus CDs, and UNDs versus CDs. To control for the violation of the assumption of sphericity, Huynh-Feldt epsilon corrections were applied and the corresponding adjusted degrees of freedom are reported for all repeated measures analyses. Partial eta squared $\left(\eta_{p}^{2}\right)$ is reported as a measure of effect size.

\section{RESULTS}

To test whether the three groups differed from each other on working for snacks across trials, an overall analysis on responses for snack food was performed with all three groups: UNDs, RNDs and CDs. A significant main effect of trial was observed, $F(2.06$, I40.18) = I0.9I, $p<$.00I, $\eta_{\mathrm{p}}{ }^{2}=$.I4. Also a significant main effect of group was found, $F(2,68)=5.04$, $p<$.oI, $\eta_{\mathrm{p}}^{2}=$. I3 . These main effects were qualified by a significant trial $\times$ group interaction, $F\left(4.12\right.$, I40.I8) $=3.05, p=.02, \eta_{\mathrm{p}}^{2}=.08$. Mean number of responses per trial for each separate group is displayed in Figure 2.I. The interaction suggests, in line with our hypotheses, that RNDs work harder to obtain snack food than UNDs, but only when these RNDs are not currently dieting. 


\section{SNACK REINFORCEMENT IN RESTRAINED EATING}

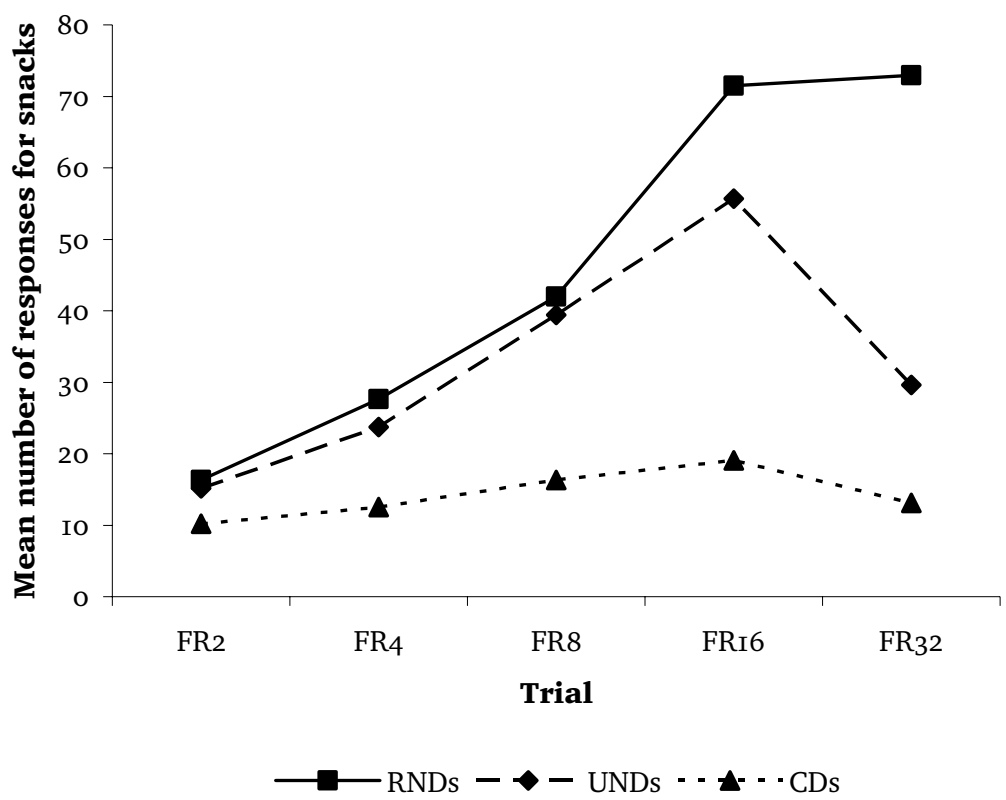

Figure 2.I. Mean responses for snack food at different trials for each separate group. Each trial denotes a different response requirement. FR refers to fixed ratio of reinforcement and the numbers refer to the number of responses required to obtain a single snack point.

To further examine the trial $\times$ group interaction, three separate analyses were conducted with only two levels for the factor group, to be able to compare each group with each other. The first of the three analyses compared UNDs with RNDs on the five trials. Again a significant main effect for trial was found, $F\left(2.04\right.$, IIO.29) $=$ I4.I4, $p<.00 I, \eta_{\mathrm{p}}{ }^{2}=.2 \mathrm{I}$. However, no significant main effect for group was found, $F(\mathrm{I}, 54)=2.23, p=. \mathrm{I} 4, \eta_{\mathrm{p}}{ }^{2}=.04$. The main effect for trial again was qualified by a significant interaction effect, $F$ (2.04, IIO.29) $=3.02, p=.05, \eta_{\mathrm{p}}^{2}=.05$. This analysis revealed that as the reinforcement ratio for snacks increases, the RNDs start working harder for snack food compared to the UNDs. As can be inferred from Figure 2.I, the number of responses for snack foods only start to diverge between these two groups with a response requirement of I6 responses per snack 


\section{ChAPTER 2}

point (i.e., trial FRI6) and this difference is significant at a response requirement of 32 responses per snack point, $t(54)=2.13, p=.04$.

In a second analysis comparing the UNDs with the CDs, a significant main effect for trial was found, $F(2.4 \mathrm{I}, \mathrm{II} 7.89)=8.56, p<.00 \mathrm{I}, \eta_{\mathrm{p}}{ }^{2}=$. .I5. Also a significant group effect was found $F(\mathrm{I}, 49)=9.47, p<.0 \mathrm{I}, \eta_{\mathrm{p}}{ }^{2}=. \mathrm{I} 6$. These trial and group effects were qualified by a significant interaction effect, meaning that UNDs work harder for snacks as reinforcement ratio increases compared to the CDs, $F(2.4 \mathrm{I}, \mathrm{II} 7.89)=3.49, p=.03, \eta_{\mathrm{p}}{ }^{2}=.07$. Post-hoc tests show that responses given for snacks differ significantly at every trial comparing UNDs with CDs, $t$ 's $>2.04$, $p$ 's $<.05$. When finally comparing the RNDs with the CDs, a significant trial effect was observed, $F(\mathrm{I} .59,52.47)=4 . \mathrm{I} 5, p=.03, \eta_{\mathrm{p}}{ }^{2}=. \mathrm{II}$, and group effect was also found significant $F(\mathrm{I}, 33)=6.70, p=. \mathrm{II}, \eta_{\mathrm{p}}{ }^{2}=. \mathrm{I} 7$. The trial $\times$ group interaction was marginally significant, $F(\mathrm{I} .59,52.47)=2.90, p=.08, \eta_{\mathrm{p}}{ }^{2}=.08$. RNDs exert more effort in obtaining high-caloric snack food than the CDs. Again post-hoc tests show that except for trial FR32, the number of responses given for snacks significantly differ at each trial, $t$ 's $>2.44$, $p$ 's $\leq$ 0.2 , for trial FR32 this difference was marginally significant, $t(33)=\mathrm{I} .96, p=.06$.

\section{Discussion}

The present study investigated the relative reinforcing value of snack food for UNDs, RNDs and CDs. In line with our hypotheses we found that RNDs are willing to work much harder to obtain high-caloric snack food when compared to UNDs. Further, CDs do not work as hard for obtaining high-caloric snacks as compared to RNDs and to UNDs. This latter finding is in line with the three factor model of dieting (Lowe, 1993), which states that CDs do restrict their caloric intake as opposed to RNDs. Lowe et al. (I99I) found that CDs especially restrict their caloric intake after a preload. It is possible that the findings in the present experiment are similar because the food rating and tasting prior to the concurrent schedules task functioned as a preload as well (although this preload was considerably smaller than usual) CDs thus work less for snack foods than RNDs. A possible explanation for this is that the explicit goal of losing weight is more salient and desirable for the current dieter, and behaviour in line with this current goal (i.e., opting for low caloric foods, and by doing so effectively avoiding the threatening snack food) is thus relatively more reinforcing than obtaining snack food. Corroborating this line of reasoning, Fishbach and Dhar (2005) demonstrated that female undergraduate students wanting to lose weight chose to have an apple or a chocolate bar after participation in a survey study depending on the degree to which they considered themselves removed from their ideal weight. The closer one per- 


\section{SNACK REINFORCEMENT IN RESTRAINED EATING}

ceived to be toward one's ideal weight, the more likely one was to opt for chocolate. Fishbach and Dhar thus state that progress along the goal of weight loss liberates one to pursue inconsistent goals, such as indulging in high-caloric snack food. Indeed, in the present study, the CDs had a higher BMI than the RNDs, and thus it is conceivable that the CDs perceive less progress in their weight loss goal than the RNDs. However, we did not directly measure perceived progress in weight loss, and thus this potential explanation at this point is somewhat speculative and requires further empirical validation. Another possibility is that the fruits and vegetables served as a "diet cue" that prompted the CDs to adhere to their intentions to restrict.

As stated above, the present pattern of results are in line with the three factor model of dieting proposed by Lowe (1993). According to this model it is hypothesized that CDs are RNDs that currently consider themselves being too heavy and start dieting, and stop their rigorous dieting once they have attained a certain amount of weight loss, after which they typically regain weight and enter into a cycle of on-and-off dieting. Recently though, Lowe and Timko (2004) proposed an alteration of the three factor model of dieting, inasmuch that current dieting would not just be a state of restrained eating, but rather refers to a separate group of people who have a longer weight-cycling history by going on-and-off dieting. The present study however, does not provide any insight into whether CDs are indeed a specific and separate group as we did not assess weight-cycling history of the participants.

In sum, the present pattern of results shows that RNDs work harder for specifically high-caloric foods than UNDs. Evidently, the relative reinforcing value of snack food is larger for RNDs than for UNDs, provided that the restrained eater is not currently dieting to lose weight. This individual difference may underlie the observed difference between RNDs and UNDs in their tendency to overeat, which has been found in past preload studies, and explains why RNDs are generally heavier than UNDs. Initial weight gain may lead to body weight and shape concerns and as such forms an impetus for dieting and a weight-cycling history. In this respect, a high relative reinforcing value of high-caloric food may be an important risk factor for obesity (see also Saelens \& Epstein, 1996). More research, particularly behavioural economic analysis of individual differences in food choice such as the present study, may prove to be beneficial for the development of more efficacious weightloss programs (Jeffery et al., 200o). Note that the present pattern of results concerns behaviour within a laboratory setting. It would be interesting to examine whether a similar pattern can also be observed outside the laboratory. It must be noted that the current study used a sample of university students with a restricted age range, which limits the generalizability of the findings. Moreover, this study used relatively small cell sizes, especially in the CDs group. Future investigations should try to replicate these findings with a larger and more representative sample. Despite these limitations the current findings may be relevant for understanding different dieting patterns and overeating. 



\section{Chapter 3}

\section{Substituting Snacks with Strawberries and Sudokus: Does Restraint Matter?}

This chapter is an adapted version of: Giesen, J. C. A. H., Havermans, R. C., \& Jansen, A. (20I0). Substituting snacks with strawberries and Sudokus: Does restraint matter? Health Psychology, 29, 222-226. 


\title{
CHAPTER 3
}

\begin{abstract}
Objective: Prior research demonstrates that fruit/vegetables and sedentary activities can serve as substitutes for high-calorie snack foods, when the behavioural costs for obtaining snack food increase. The current study investigated if fruit/vegetables are better substitutes for snacks than sedentary activities are and whether individual differences in dietary restraint play a role in how snacks are being substituted. Design: Participants $(n=59)$ performed a concurrent schedules task, in which fruit/vegetables, sedentary activities and snacks were simultaneously available. The response requirement for earning snacks increased per trial. Afterwards, dietary restraint was measured. Main Outcome Measures: The amount of responses for snacks per trial and the amount of points earned for fruit/vegetables and sedentary activity per trial. Results: When snacks are harder to obtain, participants increased working for both fruit/vegetables and sedentary activities. No differences were found for dietary restraint in the way snacks were substituted. However, high-restrained participants worked harder for snack foods than low-restrained participants. Conclusion: Fruit/vegetables and sedentary activities are both equally viable substitutes for high-calorie snack. High-calorie snacks have a higher reinforcing value for highly restrained eaters.
\end{abstract}




\section{SubsituTing SNACKS AND Dietary RestrainT}

The incidence of overweight and obesity is still increasing. Obesity can have many negative health consequences, such as type 2 diabetes and cardiovascular disease (Visscher \& Seidell, 20oI). Nowadays, too many people have poor diets, mostly containing low-nutritional, highenergy dense foods. To put a stop to the increase in this obesity epidemic, it is important to alter people's unhealthy eating behaviours to more healthy ones. People should do something else than overly consume high-calorie snack foods, but what effectively substitutes for eating snacks?

Goldfield and Epstein (2002) studied whether fruit, vegetables, and sedentary activities are good substitutes for snack food. By means of a concurrent schedules task the relative reinforcing value of snack food was measured. The relative reinforcing value of a reinforcer is measured by how hard a participant will work for this reinforcer compared to an alternative reinforcer. The amount of effort someone is prepared to invest in obtaining snack food therefore also depends on the available alternative. For instance, when the alternative itself is highly preferred, one will switch almost directly to working for this alternative when obtaining snack food requires increasingly more effort. However, one will be reluctant to switch that rapidly to working for the alternative when the alternative is far less preferred than snack food.

Goldfield and Epstein (2002) gave half of the participants this concurrent schedules task with snack food and fruit/vegetables as choice options, the other half of the participants got the same task, but instead of fruit/vegetables they were offered sedentary activities as the alternative to snacks. This study revealed that snacks were substituted by both fruit/vegetables and sedentary activities when the reinforcement ratio for snacks increased. At face value these results suggest that fruit/vegetables and sedentary activities are both equally viable substitutes for snacks. Goldfield and Epstein concluded that "the relative reinforcing value of snack foods versus fruits and vegetables is almost identical to the relative reinforcing value of snack foods when compared with sedentary activities" (Goldfield \& Epstein, 2002, p. 302), and that "normal-weight participants will shift choice from snack foods to healthy food and nonfood alternatives when access to snack foods is decreased, indicating that healthy food and nonfood alternatives can substitute for snack foods" (Goldfield \& Epstein, 2002, p. 302). However, this does not need to be the case. It is conceivable that sedentary activities or fruits are only a viable substitute for snacks when they are the sole available alternative to snacks. In daily life, however, choices rarely comprise a mere two options. According to this line of reasoning, to determine whether sedentary activities and fruit/vegetables are equally good substitutes for snacks requires all three reinforcers being offered simultaneously in a concurrent schedules task to the participant. Johnson, Bickel, and Kirshenbaum (2004) demonstrated the relevance of such a comparison. They tested whether nicotine gum and denicotinized cigarettes are good substitutes for nicotine-containing cigarettes. In this study they used similar concurrent 


\section{CHAPTER 3}

schedules tasks where the nicotine-containing cigarettes increased in behavioural costs and the substitutes were available at constant behavioural costs. There were three phases, one where nicotine gums were concurrently available with the nicotine containing cigarettes, another one where denicotinized cigarettes were concurrently available with the nicotinecontaining cigarettes and yet another one where both nicotine gum and denicotinized cigarettes were concurrently available with the nicotine containing cigarettes. If either substitute was solely available with the nicotine containing cigarettes, the nicotinecontaining cigarettes were similarly substituted for the available reinforcer, when behavioural costs for the nicotine-containing cigarettes increased. However, when all three reinforcers were available simultaneously, the nicotine containing cigarettes were almost entirely substituted by the denicotinized cigarettes, not the nicotine gum. Thus, in smokers, denicotinized cigarettes are better substitutes for normal cigarettes than nicotine gum is (Johnson et al., 2004).

Reinforcers do not have to share any characteristics to substitute for one another - a form of substitution termed private/personal substitution (Lancaster, I966; Lea, Tarpy, \& Webley, 1987) - , but generally the better the substitute the more features it shares with the product it substitutes (Madden, 2000). Substituting commodities for others that share the same characteristics, but are at lower cost is known as efficiency substitution (Lancaster, I966; Lea et al., I987).

The aim of the current study was to investigate whether fruit/vegetables are better substitutes for snacks than sedentary activities are. This was done by means of a concurrent schedules task, in which there were always three choice options: snacks, fruit/vegetables, and sedentary activities. The response requirement to obtain further snacks was progressively increased during the task and it was measured at what point during the task the participants would switch to working for any of the two alternatives and if switching to fruit/vegetables would be more prominent than switching to sedentary activities.

In previous research, we found that the relative reinforcing value of snacks differs between individuals (Giesen, Havermans, Nederkoorn, Strafaci, \& Jansen, 2009). Participants scoring relatively high on the Restraint Scale (RS; Herman \& Polivy, 1980), who were concerned about their weight but were not following any specific diet to lose weight at the time, paradoxically worked harder for access to snack food as compared to unrestrained eaters. For that reason we again wanted to test whether participants scoring relatively high on the RS, work harder for snack foods when even two alternative reinforcers are available. Furthermore, it is conceivable that especially for the high-restrained participants, the fruit/vegetables comprise a better substitute for snack food than sedentary activity does.

First, we tested whether high-restrained eaters work harder for obtaining snack food compared to low-restrained eaters, as found previously (Giesen et al., 2009). Second, we 


\section{SubsituTing SNACKS AND Dietary RestrainT}

tested whether fruit/vegetables comprise a better substitute for snack food than sedentary activity does, and whether this especially is the case for high-restrained eaters.

\section{METHOD}

\section{Participants}

Participants were 59 undergraduate students from Maastricht University in the Netherlands of which 39 were female. Students were invited to take part in an experiment concerning choice behaviour in return for course credits. Data from three (female) participants were excluded from analyses, because of technical and procedural errors. This study was approved by the institutional review board of the Faculty of Psychology at Maastricht University. A summary of participant characteristics is given in Table 3.I.

\section{Table 3.I}

Means and standard deviations of participant characteristics: age, hunger, Body Mass Index (BMI; $\mathrm{kg} / \mathrm{m}^{2}$ ), score on Restraint Scale (RS) and hedonic ratings for favourite snack, favourite fruit/vegetables and sedentary activity.

\begin{tabular}{lcc}
\hline & $M$ & $S D$ \\
\hline Age & 21.96 & 3.13 \\
Hunger $(100 \mathrm{~mm})$ & 49.50 & 21.66 \\
BMI & 22.76 & 2.78 \\
RS & 10.75 & 5.02 \\
Hedonics snacks $(0-10)$ & 7.16 & 2.20 \\
Hedonics fruit/vegetables $(0-10)$ & 8.54 & 1.57 \\
Hedonics sedentary activity $(0-10)$ & 7.27 & 2.48 \\
\hline
\end{tabular}

\section{Procedure and Materials}

When invited for participation, participants were asked to eat something three hours before the experiment and to abstain from further eating until participation. Every participant was tested individually between II AM and 6 PM. Upon arriving in the laboratory the participant received information on the experimental procedure and signed a consent form. Then the participant sampled four snack food items, four fruit/vegetable items and they were briefly 


\section{CHAPTER 3}

demonstrated four sedentary activities and rated them accordingly on hedonics (II-points scale: o "not at all appealing at the moment" to Io "highly appealing at the moment"). This was followed by a ranking task in which the participant was asked to rank the I2 different options in order of most appealing at the moment to least appealing at the moment. The food items consisted of bite size portions of cucumber, strawberries, pineapple (Del Monte Foods, San Francisco), and green grapes for the healthy category and for the snack food category there were chocolate M\&M's (Masterfoods, Veghel), chocolate chip cookies (Van Welzen, Smilde Bakery, Edam), wine gums (Bassett's, Cadbury Netherlands, Breda), and paprika flavoured chips (Lay's, Smiths Food Group, Utrecht). The activities consisted of reading popular magazines, surfing the Internet, solving Sudoku puzzles, or playing a computer game (Arkanoid; Fujita \& Sasabe, 1986). After rating and ranking the twelve different options, subjective hunger was assessed with a Ioo $\mathrm{mm}$ Visual Analogue Scale (VAS; ranging from o "not at all hungry" to Ioo "extremely hungry") and a filler questionnaire about choice behaviour was administered. This was done to create some extra time for the experimenter to enter the highest rated snack, the highest rated fruit/vegetable and the highest rated sedentary activity as choice options for the concurrent schedules task into the computer program.

After these questionnaires the participant was explained that $s /$ he could earn points for three of theI2 options s/he just evaluated and that the computer would randomly select these three options. In reality, participants always got to play for their highest rated snack, highest rated fruit/vegetable and highest rated sedentary activity. Next, the participant was explained that in total $\mathrm{s} /$ he would have to earn Ioo points by playing a game and that during the game s/he could distribute these points across the three options as preferred. The participant was explained beforehand that every ten points equalled ten grams of the matching food or one minute of time to spend on the sedentary activity and that as the game proceeded it would get harder to earn points for one of the three options. Participants were further explained that after the task they would have to eat the food and spend the minutes on the activity they had earned. This instruction served to limit the probability of socially desirable responding by the participant during the task.

The game consisted of five trials. In every trial, 20 points in total (snack points + fruit/vegetable points + activity points) had to be earned. Each trial comprised of making a series of choices. For each choice, a picture of the high-calorie snack, fruit/vegetable, and sedentary activity was presented on screen and the participant was instructed to press the key corresponding to their choice. Immediately after the key press, participants would receive feedback indicating whether they had earned a point for their choice, or not. In the first trial the reinforcement schedules for snacks and fruit or vegetables and sedentary activity were all set at FR2 (Fixed Ratio of 2), meaning that after every two responses on the same key a point was earned for the corresponding option. This FR2 reinforcement schedule 


\section{SubsituTing SNACKS AND Dietary RestrainT}

remained the same for the fruit/vegetable and activity option throughout the task. However, the reinforcement schedule for the high-caloric snack option changed with each trial, from FR2 in the first trial to FR4, FR8, FRi6 and FR32 in the fifth and last trial. So, when a participant would want to earn a point for snack food in the last trial, s/he would have to press 32 times on the same response key and thus 640 times if s/he would want all the 20 points in this trial for snack food (see also, Giesen et al., 2009; Goldfield \& Epstein, 2002; Havermans, Janssen, Giesen, Roefs, \& Jansen, 2009; Lappalainen \& Epstein, 1990; Raynor \& Epstein, 2003; Saelens \& Epstein, I996; Smith \& Epstein, I99I).

After the participant finished the task, the RS (Herman \& Polivy, 1980) was administered. Then the earned food was provided and the participant ate the food and spent the time earned on the sedentary activity. Finally, weight and height were measured and the participant was thanked for participating.

\section{Design and analysis}

For the first analysis in which we tested whether restraint status affects how hard someone works for snack food, the dependent variable is the number of responses for snacks in each trial on the concurrent schedules task. Number of responses for snacks were analyzed in a 5 (trial: FR2, FR4, FR8, FRı6, FR32) x 'Restraint score' repeated measures Analysis of Covariance (ANCOVA) with trial as within subjects factor and Restraint score as covariate. We decided to take restraint as covariate to minimize the loss of power instead of taking a median split and using it as a between subjects-factor (see, Van Breukelen \& Van Dijk, 2007).

For the second analysis, to test what reinforcer is a better substitute for snacks, the dependent variable was the number of points earned for fruit/vegetables versus sedentary activities in each trial on the concurrent schedules task. Number of points earned were analyzed in a 2 (option: fruit/vegetable vs. sedentary activity) $\times 5$ (trial: FR2, FR4, FR8, FRI6, FR32) repeated measures analysis of covariance (ANCOVA). Both option and trial were within subject factors and Restraint score was used as a covariate.

To control for the violation of the assumption of sphericity, Huynh-Feldt epsilon corrections were applied and the corresponding adjusted degrees of freedom are reported for all ANCOVA's. Partial eta squared $\left(\eta_{\mathrm{p}}^{2}\right)$ is reported as a measure of effect size. 


\section{CHAPTER 3}

\section{RESULTS}

To test for differences in relative reinforcing value of snack food with restraint, as found previously in the study by Giesen et al. (2009) an analysis with trial (FR2, FR4, FR8, FRI6, FR32) as the within subject factor and restraint score as covariate was conducted and revealed a significant main effect of trial, $F(2.53,136.84)=3.92, p=.014, \eta_{\mathrm{p}}{ }^{2}=.068$. This effect was qualified by a significant trial $\mathrm{x}$ restraint score interaction effect, $F(2.53, \mathrm{I36.84})=$ 3.I0, $p=.036, \eta_{\mathrm{p}}{ }^{2}=.054$. This result indeed shows that participants who are more restrained work harder for snack food (with increasing reinforcement ratio) than participants who are less restrained. To illustrate this finding, Figure 3.I shows the mean number of responses for snacks per trial for two groups: high- and low-restrained eaters as based on a median split $($ median $=\mathrm{II})$. Further, it is important to note that none of the hedonic ratings for snacks, fruit/vegetables and sedentary activities correlated significantly with restraint score, all $r$ 's $\leq .094, p$ 's $\geq .489$. This indicates that there were no differences in liking scores for the snacks, fruit/vegetables and sedentary activities between high- and low-restrained eaters. 


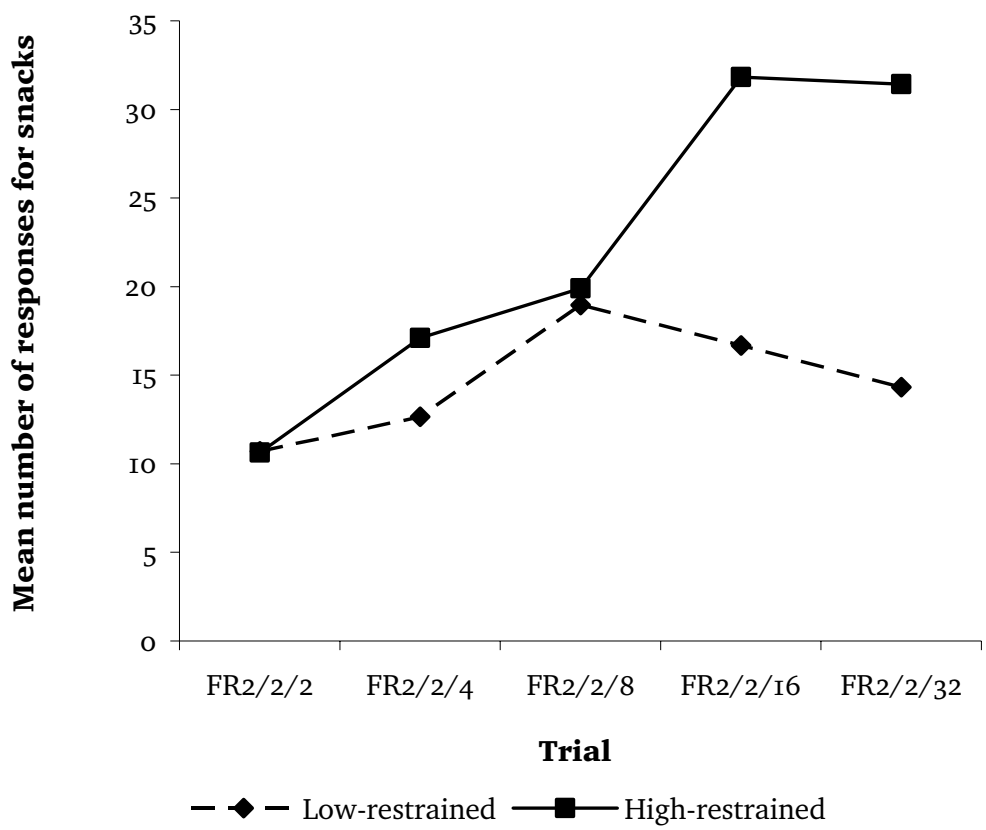

Figure 3.I. Mean number of responses for snacks per trial for high- and low-restrained eaters, based on a median split (median $=\mathrm{II}$ ). FR refers to fixed ratio of reinforcement and the numbers refer to the number of responses required to obtain a single point. Response requirement for fruit/vegetables and sedentary activities stay at FR2, whereas the response requirement for snacks increases from FR2 to FR4, FR8, FRi6 and FR32.

To test whether fruit/vegetables are a better substitute for snacks than sedentary activities, particularly for high-restrained eaters, an analysis on points earned for fruit/vegetables versus sedentary activities was performed, with restraint score as a covariate. A main effect for option was found, $F(\mathrm{I}, 54)=6.20, p=.0 \mathrm{I} 6, \eta_{\mathrm{p}}{ }^{2}=$. I03. As can be seen in Figure 3.2, participants earned more points for fruit/vegetables than for sedentary activities. Another main effect was found for trial, $F\left(3.34\right.$, I80.12) $=45.25, p<$. ooI, $\eta_{\mathrm{p}}{ }^{2}=$ .456. Again, as can be inferred from Figure 3.I, along the trials points earned for both snackalternatives increased, meaning that participants did substitute for snacks, which can also 


\section{CHAPTER 3}

be seen in the decrease in points earned for snacks. The hypothesized option $\mathrm{x}$ trial interaction, which would entail that specifically more fruit/vegetables points are earned as the response requirement for snacks increases, was not found, $F(3.25,175.30)=.309, p=.834$, $\eta_{\mathrm{p}}{ }^{2}=$.oo6. Also the three-way interaction of option $\mathrm{x}$ trial $\mathrm{x}$ restraint was not significant, $F(3.25, \mathrm{I} 75.30)=.793, p=.508, \eta_{\mathrm{p}}^{2}=.014$.

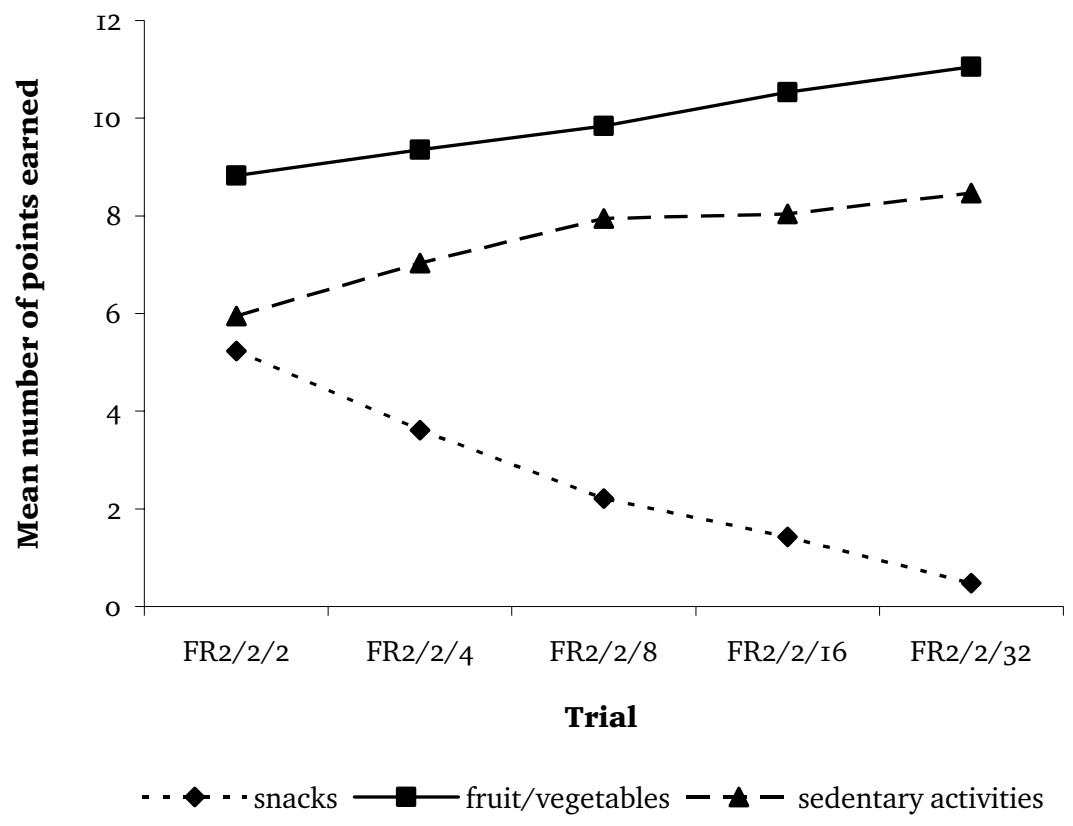

Figure 3.2. Mean number of points for fruit/vegetables, sedentary activities, and snacks per trial. Reinforcement ratios for both alternatives stay at fixed ratio 2 (FR2), whereas the reinforcement ratio for snacks increases from FR2 to FR4, FR8, FRI6 and FR32. 


\section{SubSITUTing SNACKS AND Dietary RestrainT}

\section{Discussion}

The present pattern of results shows that the more highly restrained participants increased their effort to obtain snack points as the response requirement increased, whereas the less restrained participants did not increase their efforts. In other words, the more restrained, the less one is inclined to substitute the unhealthful snacks. One can argue that snack food has a higher relative reinforcing value in high-restrained eaters.

We further hypothesized that fruit/vegetables are better substitutes for snacks than sedentary activities are, especially for high-restrained eaters. Contrary to our hypothesis, fruit/vegetables and sedentary activies both function as good substitutes for snacks, this was true regardless of restraint status. It appears that high-restrained eaters do not substitute snack food differently from low restrained eaters. Although the number of points earned for both substitutes increased as response requirement for snacks increased, it must be noted that over all trials, more points were earned consistently for fruit/vegetables than for sedentary activities. This difference in responding though is simply explained by the corresponding difference in hedonic scores between fruit/vegetables and sedentary activities (see Table 3.I). One may wonder whether the hypothesized option $\mathrm{x}$ trial interaction would have occurred if liking for fruit/vegetables and for the sedentary activities had been equal. Note though that specifically the fruit/vegetables option was liked better than the snacks and the activities, which were equally liked. In the present study, the sedentary activity option substituted for the snacks just as well as the highly liked fruit/vegetables did, thus demonstrating that some reinforcers may be less or more attractive than other reinforcers but this does not imply that it makes these reinforcers less or more effective substitutes for a given reinforcer. Therefore, it is unlikely that we would have found an option $\mathrm{x}$ trial interaction if the fruit/vegetables option was liked as much as the snacks and sedentary activities options were.

In sum, the present pattern of results shows that fruit/vegetables and sedentary activities can both substitute for snack food when behavioural costs for snack food increase. Clearly, both substitutes (i.e., sedentary activity and fruit/vegetables) are reinforcing and can substitute for the reinforcing value of the snack foods, when these latter foods become increasingly difficult to obtain. This finding complements the findings from Goldfield and Epstein (2002); furthermore, we found that the more restrained, the higher the relative reinforcing value of snack food, which also extends our earlier finding (see also Giesen et al., 2009) by showing that high-restrained participants keep working harder for snack food, even when there is more than just one alternative available. One may even argue that the present results underestimate this effect of restraint, as a clear breakpoint was not established for the high-restrained eaters, as can be seen in Figure 3.I. Would high-restrained 


\section{CHAPTER 3}

eaters also work harder for low-calorie-foods or even sedentary activities? Perhaps, but this is very unlikely, because that would imply that high-restrained eaters are more responsive to virtually any reinforcer that becomes incrementally difficult to obtain.

The concurrent schedules task used in this study is a behavioural economics task derived from animal research. Animals cannot express value into money and therefore researchers have animals work for their food. Hence, working for food in this task can be compared to spending money for food. In this case, having to work harder for snacks is similar to increasing the price of snacks (Hursh \& Silberberg, 2008). Given the present pattern of results we may speculate that people will substitute the high-calorie snacks for healthier alternatives with the introduction of a so-called fat-tax. A fat-tax refers to the policy of increasing the price of unhealthy fattening foods to curb the increasing prevalence of obesity (see e.g., Caraher \& Cowburn, 2005). The present results, however, also suggest that with a price increase of snacks only the relatively low-restrained eaters will switch to 'paying' for healthier alternatives. One may wonder whether this is a desired effect, as most studies show that especially high-restrained eaters are at risk for developing overweight or obesity (Drapeau et al., 2003; Klesges et al., I992; Lowe et al., 2006; Stice et al., I999; Stice et al., 2005). Of course, this study did not directly test the effect of a fat-tax. The snacks were made more expensive, but this was done by means of an increase in behavioural rather than monetary costs and the choice of substitutes for the snacks was atypical for environments in which a pricing strategy such as a fat-tax would be implemented (such as a restaurant, cafeteria, or supermarket). Nonetheless, we feel that the present results warrant further investigation of the potentially limited efficacy of the introduction of a fat-tax. 


\section{Chapter 4}

\section{Will Work for Snack Food: The Association of BMI and Snack Reinforcement}

This chapter is an adapted version of: Giesen, J. C. A. H., Havermans, R. C., Douven, A., Tekelenburg, M., \& Jansen, A. (20I0). Will work for snack food: The association of BMI and snack reinforcement. Obesity, I8, 966-970. 


\title{
CHAPTER 4
}

\begin{abstract}
It has been suggested that for overweight and obese individuals high-calorie foods are more reinforcing than for normal-weight individuals. It has already been shown that in contrast to sedentary activities, snack food is more reinforcing for obese women, relative to normalweight women. However, it is unclear whether overweight/obese individuals are more sensitive to the reinforcing value of food in general or more specifically to the reinforcing value of high-calorie foods. This was tested in the current study, with overweight/obese and normal-weight individuals performing a concurrent schedules task, which measures how hard someone is prepared to work for high-calorie snacks compared to low-calorie foods (e.g., fruits, vegetables), when both foods are equally liked. By gradually increasing the amount of work required to earn snacks, the relative reinforcing value of snacks was determined. As hypothesized, overweight/obese individuals work harder for high-calorie snacks compared to normal-weight individuals.
\end{abstract}




\section{OVERWEIGHT/OBESITY AND SNACK REINFORCEMENT}

Generally speaking, obesity is the result of consuming more energy than expending it. The current rise in the prevalence of obesity, then, can at least partly be explained in terms of excess caloric intake (Jéquier, 2002). Obese people particularly overeat on high-calorie foods (Drewnowski, 1996). But why would obese people overeat on specifically high-calorie foods? Several studies demonstrate that compared to normal-weight individuals, obese individuals show an increased preference for high-calorie foods, particularly for food items with a high fat content (e.g., Drewnowski, Kurth, Holden-Wiltse, \& Saari, I992; Rissanen et al., 2002). However, exactly what this apparent dietary fat preference entails is unclear.

According to Berridge (Berridge, 1996, 2007), when examining food reward, one should make a distinction between food liking and food wanting. Food liking refers to the palatability or pleasure obtained from tasting a given food, whereas food wanting refers to appetite or the motivation to eat. According to Berridge, these two processes can be dissociated. Mela (2006) argued that with regard to understanding obesity discriminating food liking and food wanting may be very important. Indeed, there are several studies suggesting that overweight/obese individuals report a stronger liking for high-calorie foods. However, this seems to be an inconsistent finding. Mela correctly pointed out that much research has failed to demonstrate a difference in liking for foods between normal-weight and overweight individuals (see e.g., Roefs \& Jansen, 2002). In a recent study with children, Hill, Wardle and Cooke (2009) found that there is no association between the liking of different types of food and obesity. Although food liking may certainly play a role in food selection and intake, the present equivocal pattern of results suggests that other processes than food liking contribute to the obese persons' caloric overconsumption. Such a process may well be food wanting and thus Mela has noted that it might be fruitful to investigate to what degree food wanting is associated with overweight/obesity.

A behavioural task that has been said to measure food wanting is a food reinforcement task (see Epstein, Truesdale, Wojcik, Paluch, \& Raynor, 2003; Havermans et al., 2009). In such a task, participants work for points that can be traded for food. However, when the task proceeds, it becomes harder to earn points. It is measured at what point someone stops working for the food, thus determining the reinforcing value of that food. A related task is a concurrent schedules task, which measures the relative reinforcing value of food. For example, Saelens and Epstein (1996) used such a task to measure the difference in reinforcing value of high-calorie foods relative to sedentary activities between obese and non-obese women. The women played a computer game in which they could earn points for highcalorie snacks and/or minutes to spend on doing a sedentary activity. Similar to the task described above is that the response requirement to earn snack points gradually increased. However, the difference between this concurrent schedule task and the food reinforcement task described earlier is that in this particular concurrent schedules task the participants cannot stop playing but have to keep working until a certain total amount of points is 


\section{CHAPTER 4}

earned. The participants nonetheless can choose not to work for snacks anymore and switch to working for minutes to spend on doing a sedentary activity for which the response requirement to earn points remains low and stable. In this way the relative reinforcing value of the snack food was determined. The results from the Saelens and Epstein (1996) study showed that obese women worked for more snack points and worked harder for snack points compared to non-obese women. This shows that the relative reinforcing value of food, or food wanting (Epstein et al., 2003), is higher in obese women compared to nonobese women. However, it is still unclear whether overweight/obese individuals are more sensitive to the relative reinforcing value of food in general or more specifically to the reinforcing value of high-calorie snack foods. To measure whether this specifically holds true for high-calorie foods and not just any food in general, one should offer low-calorie foods as the alternative to the high-calories snack foods in the task. This has already been done in several studies, very few of which, however, included overweight/obese participants (e.g., Giesen et al., 2009; Goldfield \& Epstein, 2002; Raynor \& Epstein, 2003). One study used this task in obese children, but this particular study lacks a suitable control group of lean children (Smith \& Epstein, 199I).

For the current study, we examined whether overweight/obese participants work harder for high-calorie snacks compared to a normal weight control group. If so, this would imply that the relative reinforcing value of high-calorie snacks is higher for overweight/obese individuals than normal-weight individuals. To investigate this hypothesis an overweight/obese group and a normal weight control group performed a concurrent schedules task with tasty high-calorie foods (snack food) and tasty low-calorie foods (fruit and vegetables) as choice options. By gradually increasing the amount of work required to earn the high-calorie snacks, the reinforcing value of tasty snacks relative to tasty fruits and vegetables was determined.

\section{Methods AND Procedures}

\section{Participants}

Eighty-eight undergraduate students from Maastricht University were invited to take part in a so-called study on choice behaviour and mental fatigue. When doing so, they in fact took part in two separate experiments: the present study and another unrelated study using a behavioural RT task to indirectly measure participants' evaluation of different food items, results of which will be reported elsewhere. 


\section{OVERWEIGHT/OBESITY AND SNACK REINFORCEMENT}

Students were selected based on self-reported Body Mass Index (BMI; $\mathrm{kg} / \mathrm{m}^{2}$ ). We tried to select as many candidates with a self-reported BMI $\geq 25$ as candidates with a selfreported BMI $<25$, preferably around 20 to make sure to obtain two distinct groups. Participants' actual BMI was measured at the end of participation and the assignment of participants to either the overweight/obese condition or the lean condition was determined on the basis of these actual BMIs. Participants with a BMI $\geq 25$ were classified as overweight or obese, participants with a BMI $<25$ and were classified as normal weight.

Participants had to work for food (high- and low-calorie foods) during this experiment. Based on a taste test as described below, participants would work for their highest liked snack food and their highest liked low-calorie food (i.e. fruit or vegetable). Since it is important to keep the liking for the high and low-calorie foods equal, we used the inclusion criterion that the highest liked snack food should not differ more than one point on an IIpoint Liking Likert scale from the highest liked fruit or vegetable. In total, 59 from the 88 students met this inclusion criterion. However, three participants did not follow the instructions to refrain from food two hours before the experiment and one participant was on a specific diet to gain weight. Data from these four participants were excluded from the analysis, leaving us with 55 participants, 23 (12 male) in the obese/overweight group and 32 (I4 male) in the normal weight control group. Participant characteristics are reported in Table 4.I.

Table 4.I

Means with standard errors, range and t-tests of group characteristics.

\begin{tabular}{lccccccc} 
& \multicolumn{3}{c}{ Normal weight } & \multicolumn{3}{c}{ Overweight/Obese } & \\
\cline { 2 - 7 } Variable & $M$ & $S E$ & Range & $M$ & $S E$ & Range & \\
\hline Age & 19.1 & 0.3 & $18-23$ & 19.9 & 0.4 & $17-24$ & $\mathrm{t}(53)=1.78$ \\
BMI $\left(\mathrm{kg} / \mathrm{m}^{2}\right)$ & 22.3 & 0.3 & $20.3-24.9$ & 28.8 & 0.6 & $25.2-36.6$ & $\mathrm{t}(29.3)=9.61^{*}$ \\
Hunger (100 mm VAS) & 59.6 & 3.4 & $0-82$ & 49.6 & 4.4 & $1-86$ & $\mathrm{t}(53)=1.83$ \\
$\begin{array}{l}\text { Hedonics for most liked } \\
\text { snack food (0-10) }\end{array}$ & 8.6 & 0.2 & $7-10$ & 8.7 & 0.2 & $7-10$ & $\mathrm{t}(53)=.71$ \\
$\begin{array}{l}\text { Hedonics for most liked } \\
\text { fruit or vegetable (0-10) }\end{array}$ & 8.6 & 0.2 & $7-10$ & 8.5 & 0.2 & $7-10$ & \\
\hline
\end{tabular}

$* \mathrm{p}<.001$ 


\section{CHAPTER 4}

\section{Materials and Measurements}

Foods. Participants were presented with bite-size portions of eight different food items: four items from the category 'fruit and vegetables' (cucumber [ $\pm 4 \mathrm{~g}$. .], tangerines [ $\pm 5 \mathrm{~g}$.], white grapes [ \pm 6 g.], and canned pineapple chunks [ \pm 6 g.] [Del Monte Foods, San Francisco]) and four items from the category 'snack food' (chocolate M\&M's [ \pm 3 g.] [Masterfoods, Veghel], chocolate chip cookies [ \pm 3 g.] [Van Welzen, Smilde Bakery, Edam], paprika flavoured chips [ \pm 2 g.] [Lay's, Smiths Food Group, Utrecht] and cocktail snacks [ \pm 2 g.] [Duyvis Productions, Zaandam]). These eight foods were presented in random order on a tray. We were careful not to explicitly refer to the food as "snack foods" versus "fruit and vegetables", as to prevent participants from thinking that we were mainly interested in healthful choice behaviour.

Rating and ranking task. Participants were asked to rate how much they momentarily liked the food on a paper-and-pencil task (II-points scale: o "not at all palatable at the moment" to Io "highly palatable at the moment"). This rating task was followed by a ranking task, where the participant was asked to rank the eight food items from most palatable to least palatable at this moment.

Hunger. Participants were asked to indicate their momentary hunger on a Ioo mm Visual Analogue Scale (VAS; o "not at all hungry" to Ioo "very hungry"). Hunger can influence the reinforcing value of food (Lappalainen \& Epstein, 1990) or food reward (Siep et al., 2009) and in this way we were able to check whether the groups did not differ on initial hunger and to control for possible variations in hunger.

Concurrent schedules task. Participants performed the concurrent schedules task with their favourite fruit or vegetable and their favourite snack, provided that the discrepancy in subjective liking between these two food items was equal to or smaller than I point as described above. Participants were told that the computer would randomly select two of the eight food items that they had just sampled and they were told that they had to earn points that represented the two different foods in this task.

The task consisted of five schedules and each schedule comprised of making a series of choices. For each choice, a picture of the high-calorie snack and fruit/vegetable alternative was presented on screen and the participant was instructed to press the key corresponding to either one of the food options; that is, a left response key corresponding with the highcaloric snack or a right response key corresponding with the low-caloric alternative or vice versa with assignment of key (left or right) to caloric density (high or low) being randomly determined for each separate participant. Immediately after the key press, participants would receive feedback indicating whether they had earned a point for the food item, or not. 


\section{OVERWEIGHT/OBESITY AND SNACK REINFORCEMENT}

In the first schedule the reinforcement ratio for snacks and fruit or vegetables were both set at FR2 (Fixed Ratio of 2), meaning that with every two responses on the same key a point was earned for the corresponding food. This FR2 reinforcement schedule remained the same for the fruit and vegetable option throughout the task. However, the response requirement for the high-caloric snack option doubled with every schedule, meaning that in the fifth and final schedule a participant would have to push a key twice to obtain a fruit or vegetable point and 32 times (FR32) on the other response key to earn one point for snacks.

Participants were informed that as the game proceeded it would get harder to earn points for one of the two options. Participants were explained that every ten points equals ten grams of the matching food and that they would have to eat the food that was earned after the game. In every schedule 20 points in total (snack points + fruit/vegetable points) had to be earned before proceeding to the next schedule, meaning that a total of Ioo points and thus Ioo grams of food had to be eaten directly after the task. This instruction served to limit the probability of socially desirable responding by the participant during the task.

\section{Procedure}

When invited, participants were instructed to eat two hours prior to the experiment and from that time on to refrain from food until participation. Participants were tested individually between noon and 6 PM. At arrival, participants were presented with the eight fooditems and were instructed to taste the foods and fill in the rating and ranking task. This was followed by the hunger measurement and a filler-questionnaire about choice behaviour in line with the cover story. This questionnaire allowed the experimenter time to enter the personal favourite fruit or vegetable and favourite snack as choice options in the concurrent schedules task. When finished with this filler questionnaire, participants were left alone to perform the concurrent schedules task. After performing the computer game, when having earned a total of roo food points (snack + fruit/vegetable points), participants received a second behavioural RT task pertaining to another unrelated research question, results of which will be reported elsewhere as noted above. After the RT task, participants exchanged the points they had earned previously for the foods and ate it accordingly. Although we asked participants explicitly not to discuss the experiment afterwards, we chose to have the participants actually eat the food they earned to ensure that they would not tell other (potential) participants that the choices they made did not matter. When having finished eating the foods, participants' height and weight were measured to calculate Body Mass Index (BMI; $\mathrm{kg} / \mathrm{m}^{2}$ ).

Participants received one course credit or a $€_{7.50}$ monetary voucher as remuneration for their participation. This study was approved by the research ethics committee of the Faculty of Psychology and Neuroscience of Maastricht University. 


\section{CHAPTER 4}

\section{RESULTS}

To check if liking for the snack and fruit or vegetable indeed was similar, we performed a 2 (Liking: snack vs. fruit/vegetable) x 2 (Group: normal weight vs. overweight/obese) analysis of variance (ANOVA), which showed no significant interaction effect of Liking $\mathrm{x}$ Group, $F(\mathrm{I}, 53)=\mathrm{I} .40, p=.242, \eta_{\mathrm{p}}{ }^{2}$ (partial eta squared) $=.026$, and no main effect of Liking, $F(\mathrm{I}, 53)=\mathrm{I} .40, p=.242, \eta_{\mathrm{p}}{ }^{2}=.026$ or Group, $F(\mathrm{I}, 53)=0.04, p=.835, \eta_{\mathrm{p}}{ }^{2}=$. ooI. This indicates that indeed the liking for the snack was similar to the liking for the fruit or vegetable.

To test our hypothesis that overweight/obese individuals work harder for snack food than normal-weight individuals we performed a Schedule x Group x Hunger ANCOVA, with number of responses for snack food as dependent variable. This analysis revealed significant main effects of Schedule $F(\mathrm{I} .84,95.67)=$ I2.2I, $p<.001, \eta_{\mathrm{p}}{ }^{2}=.190$ and Group $F(\mathrm{I}, 52)=$ $6.84, p=.012, \eta_{\mathrm{p}}^{2}=. \mathrm{II} 6$, which were qualified by a marginally significant Schedule $\mathrm{x}$ Group interaction effect, $F(\mathrm{I} .84,95.67)=2.64, p=.08 \mathrm{I}, \eta_{\mathrm{p}}^{2}=.048$. This implies that the more work was required to obtain snack points, the harder the overweight/obese participants tended to work for snack points as compared to normal-weight control participants. Mean number of responses per schedule for each group is displayed in Figure 4.I. The analysis revealed neither a significant main effect of the covariate Hunger nor a significant interaction effect of Hunger by Group, largest $F=2$.I4 . 


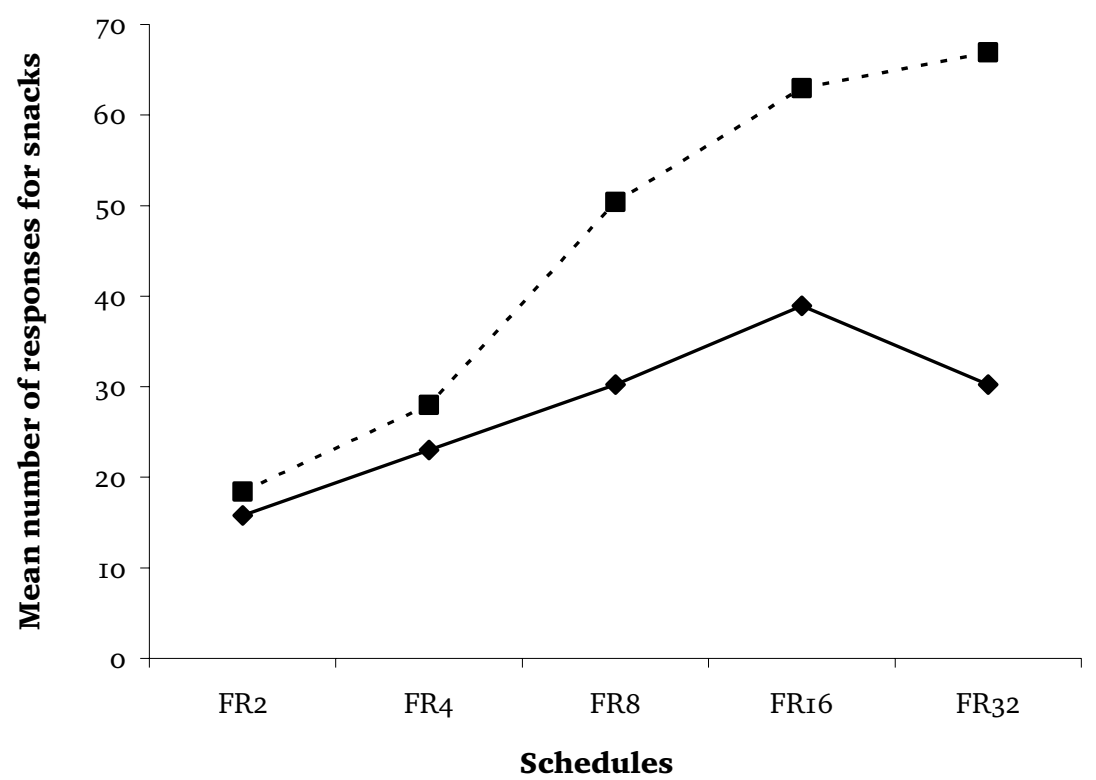

$\longrightarrow$ Normal weight $\quad-\cdot-\cdot$ - Overweight/Obese

Figure 4.I. Mean number of responses for snack food per schedule for each group. FR refers to fixed ratio of reinforcement and the numbers refer to the number of responses required to earn a single snack point.

Post-hoc tests show that there were no differences between groups in responding for snacks during the first two schedules FR2 and FR4, F's (I,52) $\leq 2.13, p$ 's $\geq .150, \eta_{\mathrm{p}}{ }^{2} s \leq .039$. The two groups, however, did differ on the last three schedules, FR8, FRI6 and FR32: F's (I,52) $\geq 4 . \mathrm{II}, p \leq .048, \eta_{\mathrm{p}}{ }^{2} \geq .073$. The covariate Hunger was only significant for the FR2 schedule, $F(\mathrm{I}, 52)=4.39, p=.04 \mathrm{I}, \eta_{\mathrm{p}}{ }^{2}=.078$.

Further, using mixed effects regression models, elasticity of demand for snacks was determined. Elasticity of demand is the change in consumption of a reinforcer relative to its price change (I9). Log values of the number of reinforcers obtained and of the reinforce- 


\section{CHAPTER 4}

ment ratios for snacks were used in the regression models. The typical regression equation looks like:

Ln Reinforcers $=\alpha+\beta_{t}$ (Ln FR) $+\beta_{2}$ (Group) $+\beta_{s}$ (Hunger) $+\beta_{4}$ [(Ln FR) x Group $]+$ $\beta_{5}$ [(Ln FR) x Hunger] $+\beta_{6}$ (Group x Hunger) $+\beta_{5}$ [(Ln FR) x Group x Hunger]. Here $\beta_{1}$ represents the demand elasticity. We tested two types of elasticity; own-price elasticity, when snack reinforcers are the dependent variable, and cross-price elasticity (Johnson \& Bickel, 2006), when fruit/vegetables reinforcers are the dependent variable. Analyses were first performed with all interactions in the model, but if these interactions were not significant they were removed from the model. Only significant interactions are reported. Note that all independent predictors remained in the model.

For the regression model with snack reinforcers as dependent variable, the estimate for own-price elasticity was significant (estimate $=-0.607, p<.00 \mathrm{I}$ ), meaning that when more work was required for snacks, the demand for snacks decreased. Group was a significant predictor of demand for snacks (estimate $=0.135, p=.02 \mathrm{I}$ ), meaning that the overweight/obese participants had a higher demand for snacks than the normal weight control participants. For the regression model with fruit/vegetables reinforcers as dependent variable, the estimate for cross-price elasticity was significant (estimate $=0.189, p<.001$ ), meaning that when more work was required for snacks, the demand for fruit/vegetables increased, suggesting that fruit/vegetables are substitutes for snacks. Group was a significant predictor of demand for fruit/vegetables (estimate $=-0.049, p=$. oII), meaning that the overweight/obese participants had a lower demand for fruit/vegetables than the normal weight control participants. However, the hypothesized Ln FR x Group interaction did not materialize. Hunger was also a significant predictor of the demand for fruit/vegetables (estimate $=-0.003, p=.002$ ), which means that the more hungry participants were, the lower the demand for fruit/vegetables was, this effect was qualified by a significant interaction effect of Ln FR $x$ Hunger (estimate $=0.002, p=.03 \mathrm{I}$ ). This is in line with the findings from the post-hoc tests that Hunger was a significant covariate on the first Schedule (FR2) and not on the other schedules.

\section{Discussion}

In this study we hypothesized that the relative reinforcing value of high-calorie snacks is higher for overweight/obese individuals compared to normal-weight controls. The results from this study show that overweight/obese individuals indeed work harder to obtain snack food compared to the normal-weight controls, confirming our hypothesis. Moreover, this 


\section{OVERWEIGHT/OBESITY AND SNACK REINFORCEMENT}

difference in the relative reinforcing value of snack foods was apparent in the absence of a difference in explicit liking for the high-calorie food, which is in line with the notion that overweight/obese show exaggerated high-calorie food wanting. This finding also stresses the notion that the value of a reinforcer cannot be equated with its palatability. Further, the analyses on the demand for snack food show that when snacks are harder to get participants substitute snacks with fruit/vegetables. In addition, the demand for snacks is higher for overweight/obese participants than for normal weight controls.

Further, from this study it can be concluded that compared to normal-weight individuals, overweight/obese individuals are sensitive specifically to the reinforcing value of high-calorie snack foods and not food in general. It seems that even when normal-weight individuals like the snacks and also the fruit/vegetables as much as the overweight/obese individuals, overweight/obese individuals are prepared to put more effort into obtaining snack food. These findings suggest that high-calorie food wanting, independent of liking, may contribute to the overconsumption of high-calorie foods in overweight/obesity.

Note that the present pattern of results does not allow us to conclude that, within participants, the reinforcing value of snacks is higher than the reinforcing value of low-calorie foods, because our design did not include a condition in which the response requirement for the fruit and vegetables option was increased relative to the snack option. This then means that it is possible that overweight/obese participants would also work harder for lowcalorie-foods with an increase in response requirement. However, this is improbable, because that would imply that overweight/obese individuals are more likely to invest energy into acquiring anything that becomes incrementally more difficult to obtain.

Interestingly, the finding that overweight/obese individuals work harder for highcalorie foods compared to normal-weight controls is in line with the findings from la Fleur et al. (2007), who found a positive correlation between working for sucrose and weight gain in rats. La Fleur and colleagues found that when rats consumed a high caloric diet for a few weeks, they started working harder for sucrose. According to these researchers, the more a rat is motivated to work for high-fat foods the more obese the rat will become, and the more obese the rat becomes the more it will want to work for food. A recent study (Hill, Saxton, Webber, Blundell, \& Wardle, 2009) found that the relative reinforcing value of food does predict weight changes in children over a period of one year. Whether this is also the case for adults and on a longer time frame is not known yet. The current study is a correlational study, and therefore we cannot conclude whether a high reinforcing value for snack food causes overeating or vice versa, or that a third factor (e.g. dietary restraint) correlating with BMI accounts for the results.

It must be noted that the current study used a sample of university students with a restricted age range, which limits the generalizability of the findings. Moreover, in our sample 


\section{CHAPTER 4}

of overweight/obese participants, only a third was obese, therefore there are limitations to comparing these results to other studies with samples of only obese participants.

In conclusion, the current study supports the notion that the relative reinforcing value of snack foods is higher for overweight /obese individuals compared to normal-weight individuals, even when liking for the food is equal. These findings may be relevant to understand overeating in obesity. Simply providing more palatable low-calorie foods will probably not help in curbing the obesity epidemic. Decreasing the reinforcing value of snack food seems to be a more viable solution. Lowering the reinforcing value for snacks foods could be accomplished by increasing the associated costs with these foods (Giesen, Havermans, \& Jansen, 20I0). Whether this is indeed beneficial in the treatment of obesity awaits empirical validation. 




\section{PART II}

INDIVIDUAL DIFFERENCES IN RESPONSE TO PUBLIC POLICY MEASURES 



\section{Chapter 5}

\section{Exploring how Calorie Information and Calorie Taxes Influence Lunch Decisions}

This chapter is an adapted version of: Giesen, J. C. A. H., Payne, C. R., Havermans, R. C., \& Jansen, A. (2010). Exploring how calorie information and taxes on high calorie foods influence lunch decisions. Manuscript submitted for publication. 


\title{
CHAPTER 5
}

\begin{abstract}
Background: The effects of public policy measures with the intention to decrease calorie consumption are rarely studied; especially how individual differences (e.g. dietary restraint) may play a role in such policy measures. Objective: The current study tested the effect of providing calorie information and a calorie tax on the number of calories chosen for lunch. Further it was investigated how these measures differently affect high and low restrained eaters. Design: I77 university students had to choose lunch from a menu three different times. The prices for the high-calorie foods increased each trial. In addition, there were three between subject factors: budget (high vs low), calorie-information (calorieinformation vs no calorie-information) and dietary restraint (high vs low). Results: There was a main effect for budget; a higher budget resulted in buying more calories. Moreover a significant three-way interaction effect of calorie tax $\mathrm{x}$ calorie information $\mathrm{x}$ restraint was observed. A calorie tax reduced the number of calories chosen for lunch, except for the highrestrained eaters who received calorie information. Conclusion: Calorie information appears to have little or no effect on the amount of calories people buy. Yet, a calorie-tax is a measure that does encourage buying fewer calories.
\end{abstract}


The incidence of overweight and obesity is increasing worldwide. Obesity is the result of a positive energy balance, more energy is consumed than expended. A simple solution, it seems, would be to eat less food - especially highly caloric foods (Swinburn et al., 2009). However, within an environment offering a wide range of readily available highly caloric foods, many people find it difficult to change their unhealthy eating behaviours or maintain healthy dietary habits. Therefore, policies designed to promote healthier food choices would be desirable. Unfortunately, there are few policy instruments specifically designed to help people make healthier food choices. Two of these policy instruments - calorie taxes and calorie information - are the focus of this research.

According to behavioural economic theory, choices leading to unhealthy behaviour can be altered to choices leading to healthier behaviour by simply increasing the price of the unhealthy choice. With regard to excessive calorie consumption, this could entail making highly caloric foods more expensive. One obvious way to do so is by introducing a calorie tax. However, the effect of such a calorie tax (or sin-tax) on food choice and consumption is still far from clear; that is, there are very few experiments directly examining whether a price change of foods causes a shift in food choice. For example, Epstein et al. (Epstein et al., 20Io; Epstein et al., 2006) found that, for children and parents, more expensive foods were purchased less, while less expensive foods were purchased more - regardless of the food's healthfulness. However, it is still not clear from these studies whether people may simply choose other highly caloric, but less expensive, foods. If this is the case, imposing a calorie tax would render tax revenues but not the desired decrease in the consumption of highcalorie foods.

Another suggestion made to change unhealthy eating behaviours is to provide a food's calorie information. Research has shown that consumers considerably underestimate the amount of calories for especially high-calorie products (Burton et al., 2006). Thus, providing calorie information might aid people in making healthier food choices. Empirically, however, results of providing calorie information have been inconsistent (Harnack \& French, 2008). These inconsistent findings may perhaps be attributed to individual differences - such as restrained eating. Restrained eaters are concerned about their body weight and shape and, as a result, attempt to attain a healthful diet by restricting their caloric intake (Herman \& Polivy, I980). It is conceivable that the effect of providing calorie information is thus largely limited to restrained eaters who already are trying to limit their caloric intake.

In the current study, both the effects of a calorie tax and providing calorie information on buying lunch was examined to gain further insight into the relative efficacy of these two policy instruments. Participants received lunch money to compose a lunch from a menu three times in a row. The products on the menu were of either high or low energy density and each energy density category contained products of both expensive and cheaper 


\section{ChAPTER 5}

products. The prices for the high-calorie products on the menu were raised each time. As a perceived increase in costs of purchasing a product does not just depend on its price but also on the magnitude of one's income, the amount of lunch money was varied between participants. Further, one group of participants was always informed of the number of calories contained by each of the products listed on the menu. We hypothesized that a calorie tax would reduce the amount of calories bought. Furthermore, we hypothesized that particularly the higher-restrained participants would buy fewer calories when provided with calorie information.

\section{METHOD}

\section{Participants}

This Institutional Review Board approved study included 178 students (95 male) from a University in the Northeast US. Students received extra credit in return for their participation. Participants were randomly assigned to the four different conditions: high budget/calorie information, high budget/no calorie information, low budget/calorie information, and low budget/no calorie information. At the end of the experiment, the Restraint Scale (RS) was administered and a median split created (median $=\mathrm{I} 4.5$ ). All four conditions were split into a high restraint and low restraint group. Participant characteristics (age, hunger, RS, and BMI [body mass index; $\mathrm{kg} / \mathrm{m}^{2}$ ]) per group are displayed in table 5.I.

\section{Procedure and Materials}

In this study participants were tested between Ir:oo AM and I:30 PM within three days time. Participants were tested in groups of maximum twenty individuals; a single test session lasted about half an hour. Upon arriving at the lab each participant took a seat in front of a computer equipped with a private shield. Participants were instructed to read the information on the screen presented in front of them and when they indicated their informed consent, they started the study. 
CAlorie Information, Calorie TAXEs, Dietary RestrainT

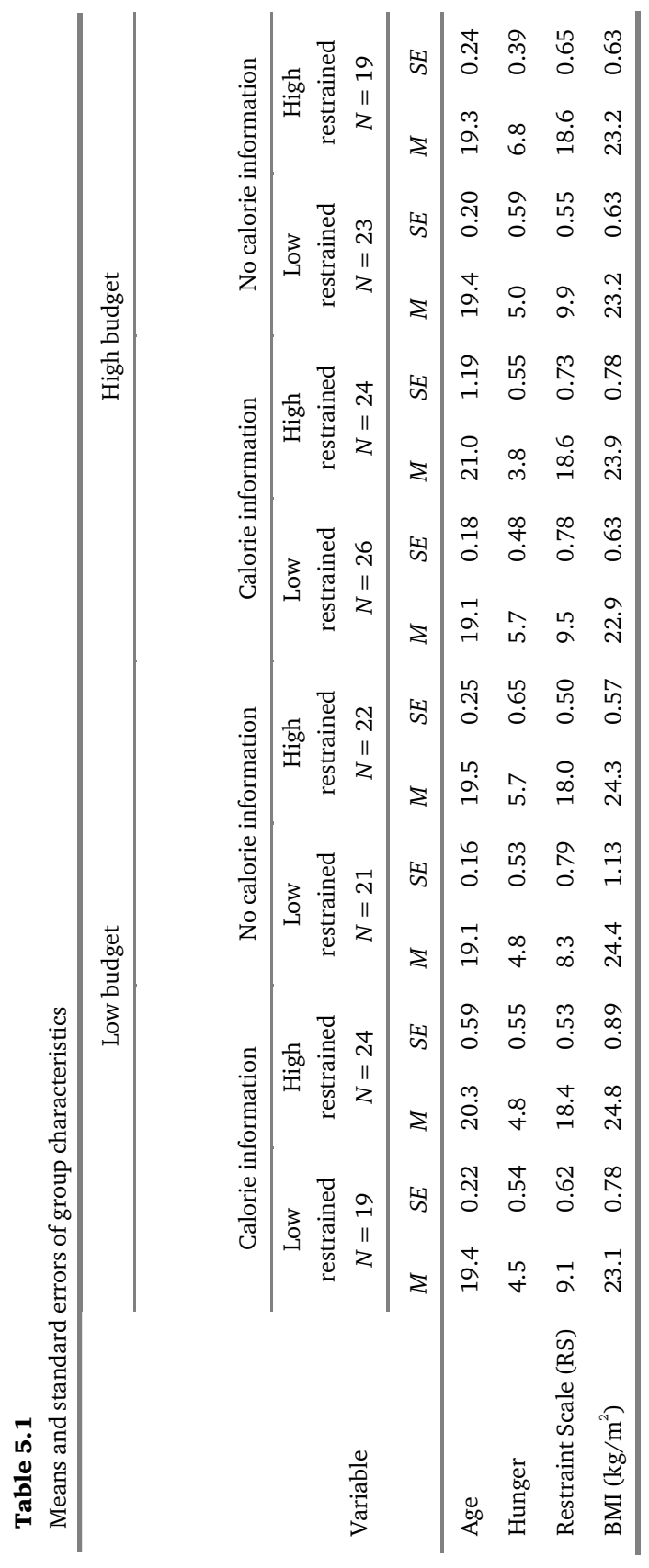




\section{ChAPTER 5}

First, momentary hunger was measured on a Io-point scale (I "not at all hungry" to Io "very hungry", and this was followed by choosing three times (a hypothetical) lunch from a menu. Participants were instructed not to exceed the amount of money they were provided with (\$10 or \$20). In total, participants chose lunch three different times. The first time the prices on the menu were based on the prices of the university's school cafeteria. The second time, the prices for the high-calorie products were set at I25\% and the third time at $150 \%$. Participants were not informed about this, but were told that something on the menu had changed the second and third time the participants had to buy a lunch. This was done because we did not want to hint directly at the price changes, and we also wanted to avoid the possibility that participants would not take the task seriously and blindly choose the same set of products with each menu. Budget and calorie information were varied between participants.

The menu consisted of three categories: Mains, Desserts and Drinks. Each category contained 4 high-calorie products and 4 low-calorie products, which were two more luxurious products (e.g. steak fajita quesadilla [high caloric]; deli sandwich veggie delite [low caloric]) and 2 cheaper products (e.g. peanut butter jelly sandwich [high caloric]; prepacked vegetable wrap [low caloric]).

After buying lunch for three times, participants completed the Restraint Scale (RS; Herman \& Polivy, 1980). This is a Io-item questionnaire concerning diet behaviour and weight fluctuations. When finished on the computer, the participants were instructed to enter a separate room where height and weight were measured. Finally the participants signed for their extra credit and were thanked for participating.

\section{Design and analysis}

The total amount of calories bought for each of three times the participants purchased lunch served as the dependent variable. Data was analysed in a 3 (tax: 100\% price, $125 \%$ price, I50\% price) x 2 (calorie information: with vs without) x 2 (budget: high vs low) x 2 (restraint: high vs low) split plot analysis of covariance (ANCOVA), with Tax as within subjects factor, Calorie information, Budget and Restraint as between subjects factors and Hunger as covariate. Hunger was entered as covariate because the groups significantly differed on initial hunger, $F(\mathrm{I}, \mathrm{I70})=4.05, p=.046, \eta_{\mathrm{p}^{2}}=.023$ (for means see Table 5.I).

Huynh-Feldt epsilon corrections were applied to control for the violation of the assumption of sphericity for all repeated measures analyses. Accordingly, the adjusted degrees of freedom are reported. Partial eta squared $\left(\eta_{p^{2}}\right)$ is reported as a measure of effect size. 


\begin{abstract}
RESULTS
A main effect for tax was found, $F(2,338)=\mathrm{I} 3.55, p<$. .ooI, $\eta_{\mathrm{p}^{2}}=.047$. This main effect was qualified by a significant interaction effect of tax x calorie information $\mathrm{x}$ restraint, $F(2,338)$ $=4.08, p=.018, \eta_{\mathrm{p}^{2}}=.024$, indicating that a price-increase lowered the number of calories bought by low-restrained participants irrespective of calorie information, whereas for highrestrained participants tax only reduced the number of calories bought without calorie information see Figure 5.I. Furthermore, there was a main effect for budget, showing that the participants who had a high spending budget bought more calories than participants with a low budget, $F(\mathrm{I}, \mathrm{I} 69)=7.53, p=.007, \eta_{\mathrm{p}^{2}}=.043$. Budget, however, did not interact with any of the other factors, smallest $p=.208$. The covariate hunger was also significant, $F(\mathrm{I}, \mathrm{I} 69)=6.42, p=.012, \eta_{\mathrm{p}^{2}}=.037$, but also did not interact with any of the other factors, smallest $p=$. I37. In other words, the hungrier the participants were the more calories they bought.

To further investigate the three-way interaction of tax $\mathrm{x}$ calorie information $\mathrm{x}$ restraint, post-hoc tests per group of restraint on tax $\mathrm{x}$ calorie information were performed, showing that in the low restrained group only tax had a significant main effect, $F(2,172)=$ II.93, $p<$.00I, $\eta_{\mathrm{p}^{2}}=$. .I22. In the high restrained group, there was a marginally significant main effect for tax, $F\left(\right.$ I.8I, I55.25) $=2.97, p=.059, \eta_{\mathrm{p}^{2}}=.033$, which was qualified by a significant interaction effect of tax x calorie information, $F\left(\right.$ I.8I, I55.25) $=4.96, p=$. oIO, $\eta_{p^{2}}$ $=.055$, meaning that tax was only effective without calorie information (see also Figure 5.I).
\end{abstract}




\section{Chapter 5}

\section{High Restrained}

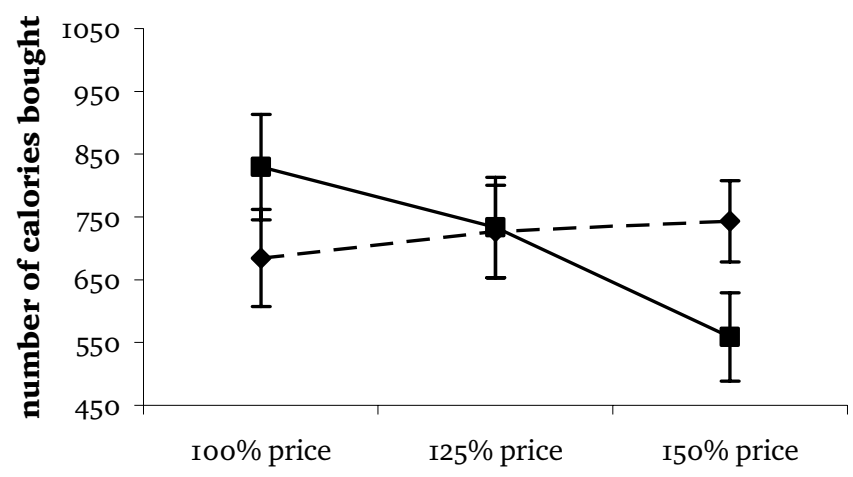

price change for high-calorie products

\section{LOW RESTRAINED}

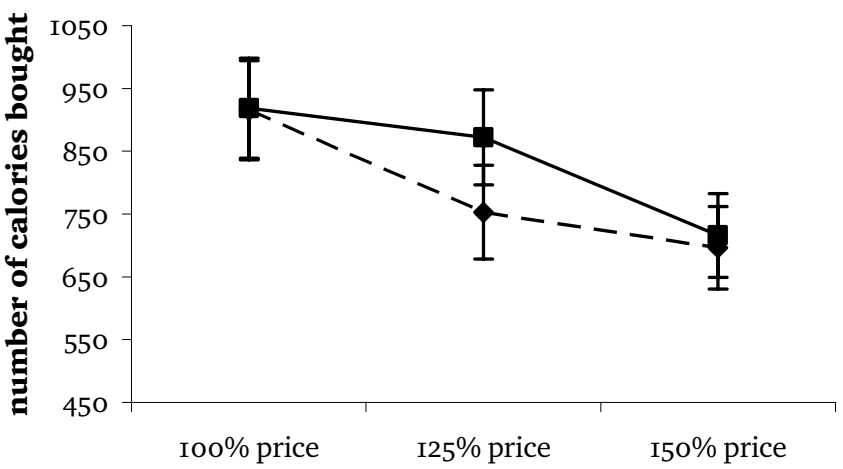

price change for high-calorie products

Figure 5.I. Number of calories bought per price change, with (- - ) or without ( - ) calorie information for the high restrained participants (top panel) and the low restrained participants (lower panel) collapsed across the factor Budget (low vs. high). 


\section{Discussion}

In the present study we investigated the effect of a calorie tax and providing calorie information on the amount of calories bought for lunch. As hypothesized, a calorie tax reduced the amount of calories people bought. Apparently, this effect occurred irrespective of the amount of money the participants could spend on buying lunch. Nevertheless, budget did matter in that the participants who had $\$ 20$ to spend bought more calories overall than the participants who only had \$Io to spend. Only the high-restrained eaters who received calorie information did not respond in an economic way to the calorie tax (see Figure 5.I). This might be explained by the fact that high-restrained eaters try to limit their calorie intake and because they receive information on the caloric content of the products they are able to adjust their energy content of their lunch to a certain caloric boundary. According to this line of reasoning, when a tax is introduced this may not be relevant for them anymore, because they already adjusted to their caloric boundary and as long as they can afford it they will buy the products. Of course, this account is speculative, and as can be inferred from Figure 5.I, the high-restrained eaters who received calorie information appear to buy fewer calories initially than the high-restrained eaters who did not get any calorie information. But note that this difference failed to reach statistical significance.

From this study it can be suggested that providing calorie information would have very little or no effect on the amount of calories people buy. A calorie tax, however, could be a policy tool that encourages buying fewer calories. Because the menu in this study offered both expensive and less expensive high-calorie products as a choice for lunch, the results also suggest that people will not substitute the purchase of expensive high-calorie foods for high-calorie cheaper products. The present study suggests that people rather switch to buying fewer calories.

Calorie information seems to prompt only high-restrained eaters to pay attention to what they buy. This, however, does not necessarily mean that providing calorie information is not a useful measure. As it happens, high-restrained eaters are mostly heavier (in this sample too, restraint score and BMI are positively correlated $r=.2 \mathrm{I} 5, p=.004$ ) and are also more at risk for weight gain (see e.g., Stice et al., 1999). So, from that point of view providing calorie information may actually be a beneficial tailored policy measure.

In sum, a profound calorie tax of $25 \%$ or higher, makes nearly everyone buy fewer calories. Calorie information on the other hand seems to interfere with taxing for those who have the intention to eat fewer calories, but in and of itself does not appear to powerfully prompt a reduction in calorie consumption (Roefs \& Jansen, 2004). Further research is necessary to be able to evaluate if smaller taxes are just as effective. If so, it should be tested whether this is also the case with a more general and representative sample. Another issue 


\section{CHAPTER 5}

that needs more research and should be examined in a more naturalistic setting is to what extent calorie information really helps restrained eaters in restricting their calorie intake. It is interesting that both measures when acting together can be counterproductive. For the restrained eaters who receive calorie information, a calorie tax does not seem to add to a more healthy food choice. As these individuals are actually at higher risk for weight gain, one may question if it is desirable to adopt a crude measure such as a calorie tax. However, this interaction of calorie information and tax too needs further research, not further speculation. 


\section{Chapter 6}

\section{Impulsivity in the Supermarket: Responses to Calorie Taxes and Subsidies}

This chapter is an adapted version of: Giesen, J. C. A. H., Havermans, R. C., Nederkoorn, C., \& Jansen, A. (2010). Impulsivity in the supermarket: Responses to calorie taxes and subsidies. Manuscript submitted for publication. 


\title{
Chapter 6
}

\begin{abstract}
The present study investigated the effect of taxing high-energy dense products and subsidizing low-energy dense products on changes in calorie consumption. More specifically, it was hypothesized that high impulsive individuals were less influenced by such pricing strategies compared to low impulsive individuals. Contrary to our hypothesis, results showed that high impulsive individuals adjusted their calorie consumption with regard to price changes whereas low impulsive participants were less influenced by price changes. Furthermore, taxing high-energy dense products was more successful in reducing calorie consumption than subsidizing low-energy dense products.
\end{abstract}




\section{CAlORIE TAXes, SubSIDIES AND IMPUlsivity}

Excessive calorie consumption is one of the main causes for the current rise in obesity (Jéquier, 2002; Swinburn et al., 2009). Therefore it is important to promote a healthier eating pattern. According to behavioural economic theory, unhealthy choices can be altered into healthier choices by increasing the price of the unhealthy choice or decreasing the price of the healthy choice. Studies using concurrent schedules tasks, where participants can work for high- and low-calorie foods, show that the majority of participants switch from highcalorie foods to low-calorie foods when more effort is required to earn high-calorie foods (e.g., Giesen, Havermans, Douven, Tekelenburg, \& Jansen, 2010; Giesen, Havermans, \& Jansen, 20I0; Giesen et al., 2009; Goldfield \& Epstein, 2002; Smith \& Epstein, I99I). Therefore it seems plausible that people will also switch from consuming or purchasing highcalorie foods to low-calorie foods when high-calorie foods become more expensive. The same shift in behaviour may be observed when low-calorie foods become cheaper.

There are only a few studies examining the effects of manipulating food price on consumer behaviour, and these studies all suggest that such pricing strategies have an immediate effect. French et al. (200I) showed that sales of low-fat snacks in vending machines could increase with $9 \%, 39 \%$ and even $93 \%$ when the prices were reduced with 10\%, $25 \%$ and $50 \%$ respectively. However, Epstein and colleagues (2010) found that subsidizing more healthful high nutrient dense foods (e.g., nonfat yogurt, broccoli) resulted in a paradoxical increase in energy intake. Why subsidizing low-energy dense products can lead to increased energy consumption is not clear. Epstein et al (2010) suggest that when low-energy dense products get subsidized, people might save money that can be spent on high-energy dense products.

The study by Epstein et al. (2010) also showed that a tax on less healthy low nutrient dense foods (e.g., Hot dogs, Potato chips) reduced energy intake. In our lab, we recently found a similar result; that is, when increasing the price (i.e., taxing) of high-calorie products on a lunch menu the number of calories chosen for lunch decreased (Giesen, Payne, Havermans, \& Jansen, 20I0). Hence, a tax on high-energy dense foods appears beneficial in promoting healthier eating (i.e. consuming less calories). Nonetheless, there are good reasons to suspect that not everyone will be equally susceptible to a high-calorie food tax. Clearly, some people find it more difficult than others to resist the temptation to indulge oneself with a high-calorie treat. Some researchers have argued that it is impulsivity that underlies this individual difference. Indeed, both overeating and overweight/obesity are associated with impulsivity (Guerrieri, Nederkoorn, \& Jansen, 2007; Jansen et al., 2009; Nederkoorn, Braet et al., 2006) Impulsivity has also been found to influence the purchase of calories from high-energy dense food products in an internet supermarket, especially hungry impulsive participants bought more calories (Nederkoorn, Guerrieri, Havermans, Roefs, \& Jansen, 2009). Impulsivity is a broad concept referring to responding with insufficient forethought, planning or control (Solanto et al., 20oI). One aspect of impulsivity is 


\section{Chapter 6}

impaired inhibitory control (Solanto et al., 20oI). It seems conceivable that someone who has difficulty overriding an automatic response to palatable high-calorie foods may not be very responsive to a price change. In other words, impulsive people presumably tend to buy snack food without much consideration of its price.

In the current study it was investigated if taxing high-energy dense foods and subsidizing low-energy dense foods influences the number of calories bought for groceries in an internet supermarket. Moreover we tested whether this tax and subsidy differently influence high impulsive individuals compared to low impulsive controls. In line with Epstein's findings (2010) we hypothesized that a tax on high-energy dense foods would be more efficient in decreasing the number of calories bought by participants, compared to a subsidy on low-energy dense foods. Further it was hypothesized that this effect would be more prominent in the low impulsive individuals.

\section{METHOD}

\section{Participants}

Participants were 82 undergraduate students from Maastricht University in the Netherlands of which 6r were female. Students were invited to take part in an experiment concerning shopping behaviour in return for course credits. Two participants had more than a $95 \%$ error rate on the stop signal task (Logan, Schachar, \& Tannock, 1997) and Io participants did not follow the instructions for the internet supermarket task. Data from these I2 (8 female) participants were excluded from analyses, leaving us with 70 participants. Participants were randomly assigned to either the tax or subsidy condition. Based on a median split on stop signal reaction time $($ SSRT) (median $=319.25)$ the two conditions were each divided in a high and low impulsive group. A summary of group characteristics is given in Table 6.I. This study was approved by the ethical committee of the Faculty of Psychology and Neuroscience at Maastricht University. 
Table 6.I

Means with standard errors of group characteristics

\begin{tabular}{lcccccccc}
\hline & \multicolumn{3}{c}{ Tax } & \multicolumn{3}{c}{ Subsidy } \\
\cline { 2 - 8 } Variable & \multicolumn{2}{c}{ Low impulsive } & \multicolumn{2}{c}{$\begin{array}{c}\text { High impulsive } \\
\mathrm{N}=15\end{array}$} & \multicolumn{2}{c}{$\begin{array}{c}\text { Low impulsive } \\
\mathrm{N}=16\end{array}$} & \multicolumn{2}{c}{ High impulsive } \\
& $M$ & $S E$ & $M$ & $S E$ & $M$ & $S E$ & $M$ & $S E$ \\
\hline Age & 21.6 & 0.46 & 21.5 & 0.57 & 21.3 & 0.37 & 22.0 & 0.63 \\
Hunger $(100 \mathrm{~mm})$ & 44.1 & 7.46 & 48.3 & 6.41 & 57.9 & 5.24 & 50.6 & 5.55 \\
BMI $\left(\mathrm{kg} / \mathrm{m}^{2}\right)$ & 23.4 & 0.70 & 22.9 & 0.79 & 23.0 & 1.19 & 23.3 & 0.64 \\
SSRT & 264.3 & 6.76 & 377.2 & 9.17 & 269.9 & 7.38 & 361.9 & 8.00 \\
\hline
\end{tabular}

\section{Procedure and materials}

Participants were tested in groups of 5 to 7 individuals, between II AM and 4 PM. Participants were instructed to refrain from eating and drinking (except water) $2 \mathrm{~h}$ prior to participation. Upon arriving in the laboratory each participant was seated in a private cubicle and was given a written description about the procedure and signed a consent form.

First, participants were asked to indicate their momentary hunger on a Ioo $\mathrm{mm}$ Visual Analogue Scale (VAS; "not at all hungry" to Ioo "very hungry") to be able to check whether the groups differed on initial hunger. Then the participants started the stop signal task (Logan et al., 1997). The stop signal task is a choice reaction time task that measures response inhibition and that has been related to impulsivity (Logan et al., 1997). In this task a participant must respond as fast as possible to a go signal (in this case, the letter 'e' or ' $u$ ') by pressing the corresponding letter on the keyboard. However, when a stop signal appears (a red circle around the letter), the response must be inhibited ( $25 \%$ of the trials). The delay of the stop-signal is initially set at $250 \mathrm{~ms}$ after the presentation of the go signal, and then dependent on the reponse from the participant adjusted dynamically. The stop signal reaction time (SSRT) is calculated by subtracting the stop delay from the reaction time (RT). A higher SSRT is regarded as lower inhibitory control. Participants first performed a short practice block of Io trials to practice reponding to the different go signals. Next, there were two blocks of 80 test trials. Between the two blocks, participants were allowed to take a short break (approximately I minute), while staying in their own cubicle.

After the stop signal task, participants were instructed to buy groceries in an internet supermarket task (Nederkoorn et al., 2009). The instruction for the students was as follows (translated from Dutch): 


\section{Chapter 6}

"Imagine it is a regular Tuesday and you have no food at home. It is time to go grocery shopping, but only for this whole day. To this end, you now receive $€$ Io to buy groceries for yourself for today. Note that you already have oil, butter and spices in stock at home. Have fun shopping!"

When finished doing groceries, they were asked to buy groceries for a second time, with almost similar instructions :

"Imagine it is Tuesday, a week later, and again you have no food at home. So you need to go grocery shopping again. The supermarket where you went last week is closed, therefore you need to go to another supermarket. You reveive $€_{\text {Io }}$ to buy groceries for yourself for this whole day. Oil, butter and spices are already in stock at home. Have fun shopping!"

The first time participants performed the internet supermarket task, the shop was the same for every participant with prices equivalent to product prices in regular supermarkets in the Netherlands. The second time, participants were randomly assigned to a tax or subsidy condition. In the tax condition, all products (drinks and juices excluded) with a energy density of $300 \mathrm{kcal} /$ Ioo $\mathrm{g}$ and above (high-energy dense products) were raised in price with $50 \%$. In the subsidy condition all products (drinks and juices excluded) with a energy density of $150 \mathrm{kcal} / \mathrm{Ioo} \mathrm{g}$ and below (low-energy dense products) were reduced in price with $50 \%$. The products with an energy density in between I5O and $300 \mathrm{kcal} / \mathrm{IOO} \mathrm{g}$ (moderate-energy dense products), plus the soft drinks, beverages and juices stayed at the same price for both condtions. The original internet supermarket (see Nederkoorn et al., 2009) was extended from 640 products to 708 food products. In total 233 products classified as high-energy dense products, $2 \mathrm{I} 7$ as moderate-energy dense products, and 258 as lowenergy dense products.

When finished with the internet supermarket task, participants were guided to a separate room where height and weight were measured to calculate Body Mass Index (BMI; $\left.\mathrm{kg} / \mathrm{m}^{2}\right)$.

\section{Design and Analyses}

The dependent variable was the difference in the number of calories bought between the first supermarket with normal price and the second supermarket with tax or subsidy (supermarket 2 - supermarket I). A negative score thus represents a decrease in calories bought, whereas a positive score indicates an increase in purchased calories. We calculated four difference scores: (I) for the total number of calories; (2) for the number of calories 


\section{CAlorie TAXes, Subsidies AND IMPUlsivity}

from the high-energy dense products; (3) for the number of calories from the moderateenergy dense products; and (4) for the number of calories from the low-energy dense products. Data were analyzed in four 2 (condition: tax vs subsidy) x 2 (impulsivity: low impulsive vs high impulsive) ANOVAs (analysis of variance). Partial eta squared $\left(\eta_{p^{2}}\right)$ is reported as a measure of effect size.

\section{RESULTS}

\section{Participants}

To test if groups differed in age, initial hunger, BMI and SSRT, separate ANOVA's on these group characteristics were conducted. The analysis concerning age revealed no main effects for condition $F(\mathrm{I}, 66)=.02, p=.886, \eta_{\mathrm{p}^{2}}<.00 \mathrm{I}$, or impulsivity $F(\mathrm{I}, 66)=.39, p=.535, \eta_{\mathrm{p}^{2}}$ $=.006$. Further, there was no significant interaction effect for condition $\mathrm{x}$ impulsivity, $F(\mathrm{I}$, $66)=.67, p=.418, \eta_{\mathrm{p}^{2}}=$. oIo, indicating that the groups did not differ in age.

With regard to hunger, no main effects were found for either condition $F(\mathrm{I}, 66)=$ I.74, $p=.192, \eta_{\mathrm{p}^{2}}=.026$ or impulsivity $F(\mathrm{I}, 66)=.06, p=.800, \eta_{\mathrm{p}^{2}}=.001$. No significant condition $\mathrm{x}$ impulsivity interaction effect was found, $F(\mathrm{I}, 66)=.86, p=.357, \eta_{\mathrm{p}^{2}}=.0 \mathrm{oI} 3$, indicating that the groups did not differ on initial hunger.

For BMI, similar results were found, that is, no main effects for condition $F\left(\mathrm{I}, 64^{2}\right)<$ .oI, $p=.966, \eta_{\mathrm{p}^{2}}<$.ooI and for impulsivity, $F(\mathrm{I}, 64)=.02, p=.880, \eta_{\mathrm{p}^{2}}<.00 \mathrm{I}$, and the absence of an interaction effect for condition $\mathrm{x}$ impulsivity, $F(\mathrm{I}, 64)=.19, p=.664, \eta_{\mathrm{p}^{2}}=$ .003 was found suggesting that the groups did not differ in BMI.

As expected, for SSRT there was a significant main effect for impulsivity, $F(\mathrm{I}, 66)=$ I65.20, $p<.00 \mathrm{I}, \eta_{\mathrm{p}^{2}}=.715$, indicating that the median split on SSRT resulted in two distinctive groups. Neither a main effect for condition was found, $F(\mathrm{I}, 66)=.37, p=.546, \eta_{\mathrm{p}^{2}}=$ .006 , nor a significant interaction effect for condition $\mathrm{x}$ impulsivity, $F(\mathrm{I}, 66)=\mathrm{I} .7 \mathrm{I}, p=. \mathrm{I} 95$, $\eta_{\mathrm{p}^{2}}=.025$.

${ }^{2}$ Note that the degrees of freedom are different from the other analysis, because of missing variables in two cases. 


\section{Chapter 6}

\section{Total calories}

To check for pre-test differences between groups a 2 (condition: tax vs subsidy) x 2 (impulsivity: low impulsive vs high impulsive) ANOVA on the number of calories bought in the first supermarket was performed. This analysis revealed no main effects for condition, $F(\mathrm{I}, 66)=$ $.19, p=.663, \eta_{\mathrm{p}^{2}}=.003$, or impulsivity, $F(\mathrm{I}, 66)=.90, p=.346, \eta_{\mathrm{p}^{2}}=.013$. Further, the interaction effect of condition $\mathrm{x}$ impulsivity was not significant, $F(\mathrm{I}, 66)=\mathrm{I} .05, p=.3 \mathrm{IO}, \eta_{\mathrm{p}^{2}}$ $=$. oI6, suggesting that the groups did not differ on the number of calories bought in the first supermarket.

The ANOVA on difference scores for total calories revealed a significant main effect for condition $F(\mathrm{I}, 66)=7.73, p=.007, \eta_{\mathrm{p}^{2}}=$. .105. This main effect was qualified by a marginally significant interaction effect of condition $\mathrm{x}$ impulsivity, $F(\mathrm{I}, 66)=3.24, p=.076$, $\eta_{p^{2}}=.047$. This interaction effect suggests that in the tax condition, only high impulsive participants decrease the number of calories they buy, whereas in the subsidy condition, low impulsive and even more so high impulsive participants increase the number of calories, as can be seen in Figure 6.I. No significant main effect was found for impulsivity, $F(\mathrm{I}, 66)<$ .oor.

\section{TOTAL CALORIES}

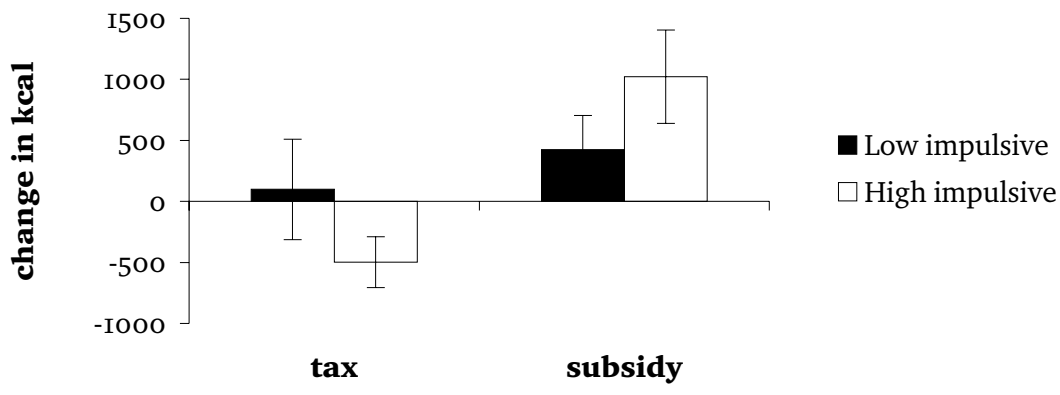

Figure 6.I. Change in calories between first time shopping en second time shopping, for high and low impulsive individuals in the tax and subsidy condition. The error bars represent one standard error. A negative score constitutes a decrease in calories; a positive score represents an increase in calories. 


\section{CAlORIE TAXes, Subsidies AND IMPUlsivity}

Post-hoc tests testing whether the high and low Impulsive groups differ from each other within condition revealed no significant effects (within tax: $t(29)=\mathrm{I} .32, p=. \mathrm{I} 97$; within subsidy: $t(37)=\mathrm{I} .27, p=.2 \mathrm{II})$. We further tested whether per group the change in calories between the first and second supermarket was significant. These analyses revealed that the high impulsive participants significantly decreased the number of calories purchased in the tax condition, $t(\mathrm{I5})=2.4 \mathrm{I}, p=.03$, and increased the number of calories bought in the subsidy condition, $t(\mathrm{I} 8)=2.67, p=.0 \mathrm{I} 6$. For the low Impulsive participants no significant changes in total calorie purchase were found for either the tax or subsidy condition, $t$ 's $<$ I.52, $p$ 's $>$.I44.

\section{Calories from the high-energy dense products}

To check for pre-test differences between groups a 2 (condition: tax vs subsidy) x 2 (impulsivity: low impulsive vs high impulsive) ANOVA on the number of calories bought from high-energy dense products in the first supermarket was performed. This analysis revealed no main effects for condition, $F(\mathrm{I}, 66)=\mathrm{I} .34, p=.25 \mathrm{I}, \eta_{\mathrm{p}^{2}}=.020$, or impulsivity, $F(\mathrm{I}, 66)=$ $.66, p=.4 \mathrm{I} 8, \eta_{\mathrm{p}^{2}}=$.oІо. Also the interaction effect of condition $\mathrm{x}$ impulsivity was not significant, $F(\mathrm{I}, 66)=\mathrm{I} .32, p=.254, \eta_{\mathrm{p}^{2}}=.020$. These results suggest that the groups did not differ in the number of calories bought from high-energy dense products in the first supermarket.

To examine whether tax or subsidy had a specific effect on the calories bought from high-energy dense products an ANOVA was performed on the difference scores for calories of high-energy dense products. This analysis revealed no significant main effects for either condition, $F(\mathrm{I}, 66)=\mathrm{I} . \mathrm{I} 4, p=.289, \eta_{\mathrm{p}^{2}}=$. oI7, or impulsivity, $F(\mathrm{I}, 66)=.26, p=.6 \mathrm{I} 2, \eta_{\mathrm{p}^{2}}=$ .004. However, a significant interaction effect of condition $\mathrm{x}$ impulsivity was found, $F(\mathrm{I}, 66)$ $=8.15, p=.006, \eta_{p^{2}}=$. IIo, showing that in the tax condition the high impulsive participants decreased the number of calories bought from high-energy dense products, whereas the low impulsive participants slightly increased the number of calories. In the subsidy condition this pattern was reversed, see Figure 6.2. 


\section{Chapter 6}

\section{CALORIES FROM THE HIGH-ENERGY DENSE PRODUCTS}

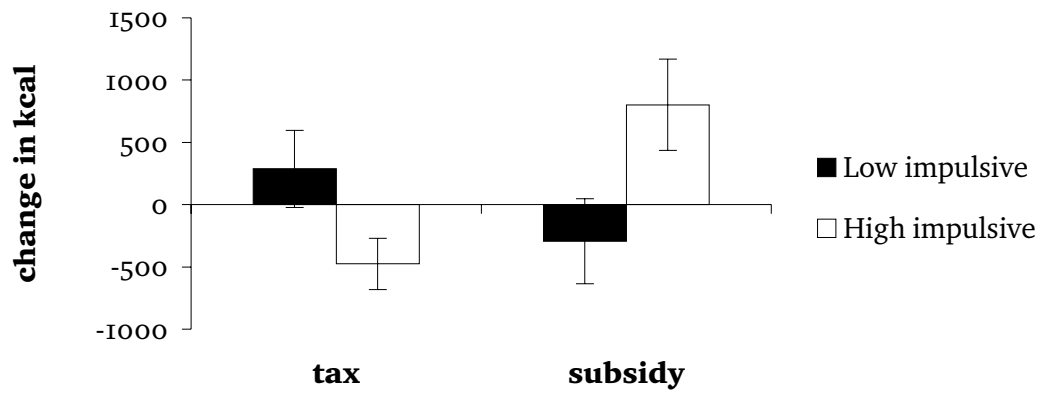

Figure 6.2. Change in calories from the high-energy dense products between first time shopping en second time shopping, for high and low impulsive individuals in the tax and subsidy condition. The error bars represent one standard error. A negative score constitutes a decrease in calories; a positive score represents an increase in calories.

Post-hoc tests revealed that high and low impulsive participants significantly differed from each other in the tax condition, $t(29)=2.07, p=.047$ and in the subsidy condition, $t(37)=2.19, p=.035$. The high impulsive participants significantly decreased the number of calories bought from the high-energy dense products in the tax condition, $t$ (I5) $=2.30, p$ $=.036$, and in the subsidy condition the high impulsive participants significantly increased the number of calories purchased, $t$ (I8) $=2.19, p=.042$. Changes in bought calories for the low impulsive participants were not significant, $t$ 's $<.93$, $p$ 's $>.369$.

\section{Calories from the moderate-energy dense products}

To check for pre-test differences between groups a 2 (condition: tax vs subsidy) x 2 (impulsivity: low impulsive vs high impulsive) ANOVA on the number of calories bought from moderate-energy dense products in the first supermarket was performed. This analysis 
revealed no main effects for condition, $F(\mathrm{I}, 66)=.07, p=.792, \eta_{\mathrm{p}^{2}}=.00 \mathrm{I}$, or impulsivity, $F(\mathrm{I}, 66)=.09, p=.764, \eta_{\mathrm{p}^{2}}=.001$. Also the interaction effect of condition $\mathrm{x}$ impulsivity was not significant, $F(\mathrm{I}, 66)=.33, p=.568, \eta_{\mathrm{p}^{2}}=.005$. These results suggest that the groups did not differ on the number of calories bought from moderate-energy dense products in the first supermarket.

Tax, subsidy or impulsivity seemed to have little or no effect on the consumption of moderate-energy dense products, see Figure 6.3. No main effects for condition, $F(\mathrm{I}, 66)=$ $.80, p=.375, \eta_{p^{2}}=.012$, or for impulsivity were found, $F(\mathrm{I}, 66)=.18, p=.685, \eta_{p^{2}}=.003$. There was no condition $\mathrm{x}$ impulsivity interaction effect, $F(\mathrm{I}, 66)=. \mathrm{IO}, p=.753, \eta_{\mathrm{p}^{2}}=.002$. As is displayed in Figure 6.3, low and high impulsive participants show only minimal changes in calories from moderate-energy dense products for both tax and subsidy.

\section{CALORIES FROM THE MODERATE-ENERGY DENSE PRODUCTS}

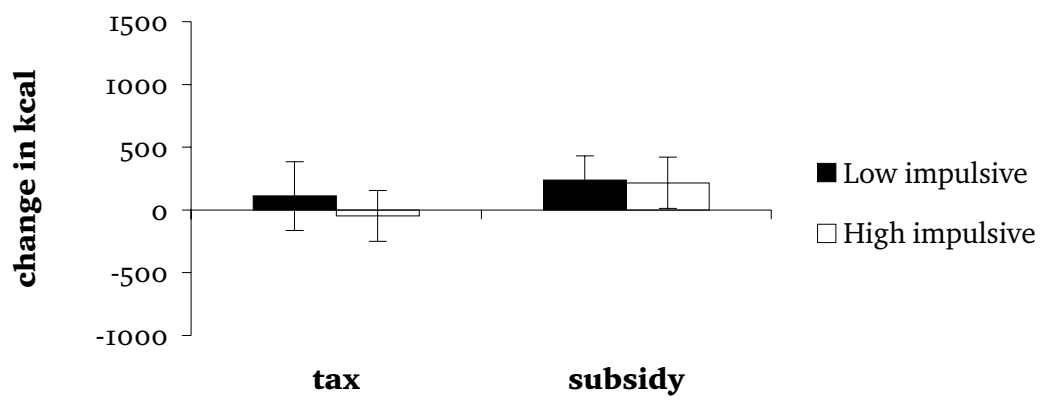

Figure 6.3. Change in calories from moderate-energy dense products between first time shopping en second time shopping, for high and low impulsive individuals in the tax and subsidy condition. The error bars represent one standard error. A negative score constitutes a decrease in calories; a positive score represents an increase in calories. 


\section{Chapter 6}

\section{Calories from the low-energy dense products}

To check for pre-test differences between groups a 2 (condition: tax vs subsidy) x 2 (impulsivity: low impulsive vs high impulsive) ANOVA on the number of calories bought from lowenergy dense products in the first supermarket was performed. This analysis revealed no main effects for condition, $F(\mathrm{I}, 66)=\mathrm{I} .93, p=.170, \eta_{\mathrm{p}^{2}}=.028$, or for impulsivity, $F(\mathrm{I}, 66)=$ $.5 \mathrm{I}, p=.480, \eta_{\mathrm{p}^{2}}=.008$. Further, the interaction effect of condition $\mathrm{x}$ impulsivity proved not significant, $F(\mathrm{I}, 66)=\mathrm{I} .32, p=.255, \eta_{\mathrm{p}^{2}}=.020$, suggesting that the groups did not differ on the number of calories bought from low-energy dense products in the first supermarket.

The ANOVA on the difference scores for the calories from the low-energy dense products showed a significant main effect of condition, $F(\mathrm{I}, 66)=6.67, p=.0 \mathrm{I} 2, \eta_{\mathrm{p}^{2}}=.092$, which was qualified by a significant interaction effect of condition $\mathrm{x}$ impulsivity, $F(\mathrm{I}, 66)=$ 7.4I, $p=.008, \eta_{\mathrm{p}^{2}}=$.IoI. No significant main effect was found for impulsivity, $F(\mathrm{I}, 66)=$ $.27, p=.604, \eta_{\mathrm{p}^{2}}=.004$. As can be seen in Figure 6.4, the low impulsive participants in the tax condition decreased their purchase of calories from the low-energy dense products whereas in the subsidy condition they increased their purchase of calories from the lowenergy dense products. The high-impulsive participants showed no change in buying calories for low-energy dense products in both conditions. 


\section{CALORIES FROM THE LOW-ENERGY DENSE PRODUCTS}

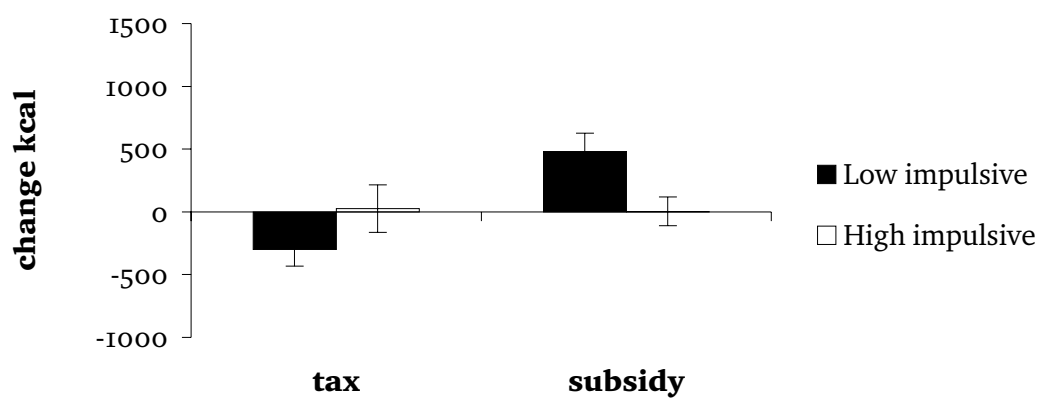

Figure 6.4. Change in calories from low-energy dense products between first time shopping en second time shopping, for high and low individuals in the tax and subsidy condition. The error bars represent one standard error. A negative score constitutes a decrease in calories; a positive score represents an increase in calories.

Post-hoc tests revealed no difference between high- and low impulsive participants in the tax condition, $t(29)=\mathrm{I} .38, p=. \mathrm{I} 77$, but they did differ in the subsidy condition, $t(37)=$ $2.58, p=.014$. As suggested above, only the low impulsive participants significantly changed the number of calories purchased in the tax condition, $t$ (I4) $=2.25, p=.04$ I. And in the subsidy condition, they bought more calories from the subsidized low-energy dense products and less calories from low-energy dense products in the tax condition, $t$ (I9) $=3.35, p=$ .003. For the high impulsive participants changes were not significant, $t$ 's $<.13$, $p$ 's $>.897$.

The absolute number of calories bought per group, for all products, high-energy dense products, moderate-dense products, and low-energy dense products in both supermarket I and 2 are displayed in table 6.2 . 


\section{Chapter 6}

Table 6.2

Means with standard errors of kcal bought per group

\begin{tabular}{|c|c|c|c|c|c|c|c|c|}
\hline \multirow{3}{*}{ Variable } & \multicolumn{4}{|c|}{ Tax } & \multicolumn{4}{|c|}{ Subsidy } \\
\hline & \multicolumn{2}{|c|}{$\begin{array}{c}\text { Low } \\
\text { impulsive } \\
\mathrm{N}=15\end{array}$} & \multicolumn{2}{|c|}{$\begin{array}{c}\text { High } \\
\text { impulsive } \\
\mathrm{N}=16\end{array}$} & \multicolumn{2}{|c|}{$\begin{array}{c}\text { Low } \\
\text { impulsive } \\
\mathrm{N}=20\end{array}$} & \multicolumn{2}{|c|}{$\begin{array}{c}\text { High } \\
\text { impulsive } \\
\mathrm{N}=19\end{array}$} \\
\hline & $M$ & $S E$ & $M$ & $S E$ & $M$ & $S E$ & $M$ & $S E$ \\
\hline \multicolumn{9}{|l|}{ First Supermarket } \\
\hline Total calories & 3797 & 362 & 4358 & 387 & 4213 & 235 & 4192 & 152 \\
\hline Calories high-energy dense & 1379 & 267 & 1947 & 360 & 2046 & 292 & 1949 & 222 \\
\hline Calories moderate-energy dense & 1451 & 158 & 1497 & 196 & 1503 & 161 & 1357 & 147 \\
\hline Calories low-energy dense & 967 & 118 & 915 & 99 & 664 & 103 & 886 & 142 \\
\hline \multicolumn{9}{|l|}{ Second Supermarket } \\
\hline Total calories & 3896 & 304 & 3860 & 277 & 4637 & 257 & 5214 & 353 \\
\hline Calories high-energy dense & 1666 & 224 & 1471 & 327 & 1752 & 268 & 2750 & 261 \\
\hline Calories moderate-energy dense & 1562 & 219 & 1449 & 153 & 1740 & 212 & 1573 & 178 \\
\hline Calories low-energy dense & 668 & 73 & 940 & 170 & 1146 & 124 & 890 & 108 \\
\hline
\end{tabular}

\section{Discussion}

The present study investigated the effect of a calorie tax on high-energy dense products and a subsidy for low-energy dense products on the number of calories purchased. Furthermore, it was investigated if high impulsive individuals are less influenced by price changes compared to less impulsive individuals.

Contrary to our hypothesis, we found that especially the more impulsive individuals with lower response inhibition responded to the price changes. In the tax condition, high impulsive individuals decreased the number of calories they bought. These calories were mainly purchased from high-energy dense products. In the subsidy condition, the high impulsive individuals increased the number of calories they bought, also mainly from highenergy dense products. The high impulsive participants did not change their purchase of low-energy dense products in the subsidy condition. However, since low-energy dense products were cheaper in the subsidy condition, money was saved on these products that in turn could be spent on high-energy dense products. The low impulsive participants in- 


\section{CAlorie TAXes, Subsidies AND IMPUlsivity}

creased the number of bought calories from low-energy dense products in the subsidy condition. It can thus be concluded that for low impulsive people a subsidy on low-energy dense products is effective in generating a healthier diet with relatively more low-energy dense products. For high impulsive people a subsidy appears however counterproductive leading to the purchase of more high-energy dense products. For high impulsive people a tax on high-energy dense products results in a healthier diet: the tax leads them to buy less high-energy dense products. Low impulsive people are unaffected by this intervention.

It is possible that low impulsive individuals adhere to a meticulous approach to buying their groceries. Therefore, when a tax or subsidy is introduced they do not readily change their shopping list, because they carefully thought about each product on that list. Consequently they stick to their list and only add some cheaper low-energy dense products. For the high impulsive individuals it might be that the first time grocery shopping was not really that well-planned, but the second time, when the prices changed in the tax condition, they quickly noticed that they would run out of budget much faster, and then reconsidered their groceries. In the subsidy condition, they actually saved money on the low-energy dense products, so that they could indulge more on the high-energy dense products. This is of course post-hoc reasoning and more research is required to find out why impulsive persons are more sensitive to product price manipulations.

The present study corroborates the notion that subsidizing low-energy dense food is beneficial for one group of people (low impulsive) whereas it appears counterproductive in another group of people (high impulsive). However, taxing high-energy dense products is not disadvantageous for any group. Impulsive people even seem to profit from the calorie tax as they adjusted their purchase of high-energy dense food products. 



\section{Chapter 7}

\section{General Discussion}




\section{CHAPTER 7}

Skinner (1938) specifically argued that behaviour is controlled by its consequences. A positive reinforcer, such as a palatable food reward, strengthens antecedent behaviour. From behavioural economics we know that such behaviour also involves costs. It takes effort, or in other words it costs energy. The more costs one is willing to make for a given reward, or the higher the price one is willing to pay for the reward, expresses one's desire for it. This is also true for food reward.

In the present environment, not everyone is obese. In terms of behavioural economics, some people are apparently more sensitive to snack food reward and hence more inclined to invest effort in obtaining this reward. In this thesis a behavioural economic approach was used to investigate hypothesized individual differences in the relative reinforcing value of high-energy dense foods (Part I).

Although currently not everyone is obese, the incidence of overweight and obesity is high and still increasing (Centraal Bureau voor de Statistiek, 2009). As weight gain can be largely attributed to unhealthy food choice (i.e., consuming to much calories; Jéquier, 2002; Swinburn et al., 2009), curbing the obesity epidemic requires people to make healthier food choices; i.e., to eat more fruit and vegetables and less high-calorie snack foods. According to a behavioural economic perspective food choice can be changed by manipulation of the accompanying costs. In the present thesis, it was investigated if public policy measures aimed at discouraging excessive calorie intake by manipulating food price influences consumer behaviour. Finally, the most interesting question is whether these measures differentially affect food choice for individuals known to be more vulnerable to overeating. This was studied in Part II. In the following sections, an overview is provided of the main findings from the studies presented in this thesis, followed by a discussion on the theoretical and societal relevance of these findings. Suggestions for future research will be discussed.

\section{OVERVIEW OF EMPIRICAL FINDINGS}

\section{Part I: Individual differences in the relative reinforcing value of food}

The first study (chapter 2) tested the hypothesis that the relative reinforcing value of snack foods is higher for restrained eaters who are currently not dieting to lose weight compared to unrestrained eaters and current dieters. In line with the hypotheses, it was found that non-dieting restrained eaters are willing to work harder to obtain snack foods compared to unrestrained eaters. Furthermore, it was found that current dieters do not work as hard for obtaining snacks as compared to non-dieting restrained eaters and unrestrained eaters. 
Based on findings from Goldfield and Epstein (2002) that both fruit/vegetables and sedentary activities are good substitutes for high-energy dense snack foods when behavioural costs for snacks increase, the study in chapter 3 investigated if fruit/vegetables are better substitutes for snacks than sedentary activities are. This was accomplished by offering a concurrent schedules task with three choice options: snacks, fruit/vegetables, and sedentary activities. In this way it was also possible to test if the finding from chapter 2, that is that the relative reinforcing value for snack foods is higher in restrained eaters compared to unrestrained eaters, holds true when more than I alternative for snacks is available. Furthermore, it was investigated if individual differences in dietary restraint play a role in how snacks are being substituted. Results showed that participants increased working for both fruit/vegetables and sedentary activities (e.g., reading magazines), when more effort for obtaining snacks was required. The more restrained participants are, the harder they work for snack foods even with the two alternative options available. However, more restrained participants did not substitute snacks differently from less restrained participants. Overall, both sedentary activities and low-calorie foods appeared to be viable substitutes for highcalorie snack foods.

Saelens and Epstein (1996) showed that relative to sedentary activity, snacks are more reinforcing for obese women compared to normal weight women. In chapter 4 it was investigated if overweight/obese individuals are more sensitive to the reinforcing value of food in general or in particular for the reinforcing value of high-calorie foods. In line with the hypothesis, it was demonstrated that overweight/obese participants worked harder for snack foods compared to normal weight participants and the demand for snacks was higher in the overweight/ obese participants (i.e., they earned more snack points) than the normal weight controls. Note that this does not mean that the overweight participants also obtained an amount of snack foods larger than the earned amount of fruit/vegetables. However, for the snack points they did earn, more effort was invested showing that the relative reinforcing value of particularly high-calorie foods is higher in overweight/obese people even when fruit/vegetables were liked to the same degree as the high-energy dense snacks. Further, subjective liking for these foods did not differ between the two groups (i.e., overweight/obese vs. normal-weight). Therefore, one may conclude that the concurrent schedules task objectively assesses one's motivation for snack foods relative to an alternative option such as fruit, and unlike self-report of food liking is able to discriminate food preferences between overweight and normal-weight persons.

\section{Part II: Individual differences in response to public policy measures}

Chapter 5 concerns a study testing the effects of two policy measures on choosing lunch: (I) a calorie tax and (2) calorie labelling. It was investigated how these measures differentially 


\section{CHAPTER 7}

affect high and low restrained eaters. As hypothesized, a calorie tax reduced the total amount of calories that people bought for lunch. Calorie labelling had little or no effect on the number of calories purchased for lunch. Notably, the high restrained eaters did not respond to the calorie tax anymore when also presented with calorie labelling.

In chapter 6 it was tested if taxing high-energy dense foods and subsidizing lowenergy dense foods influences high and low impulsive individuals differently in their calorie buying behaviour in an online supermarket. It was hypothesized that highly impulsive people would primarily be sensitive to the motivational appeal of high-calorie foods and hence less responsive to any price manipulations. Contrary to the hypothesis it was found that high impulsive individuals are especially sensitive to price changes; that is, they decreased the total number of calories purchased when a tax on high-energy dense foods was introduced and they bought more calories when a subsidy on low-energy dense foods was applied. The low impulsive people responded less to such price changes, but when confronted with a subsidy on low-energy dense products, they increased their purchase of these products.

\section{RELATIVE REINFORCING VALUE AND OVEREATING}

In the first three studies (chapters 2 through 4 ), the overall finding is that the relative reinforcing value for specifically high-calorie snack foods is higher in individuals who are prone to overeating, that is high restrained eaters and overweight/obese persons as compared to those individuals without such a tendency to overeat. Clearly, a higher reinforcing value is related to a tendency to overeat. The causality of this relation has not been tested in this thesis. Nevertheless, a likely explanation is that the relation between reinforcing value of food and food consumption is reciprocal: food consumption strengthens the reinforcing value of that food and its reinforcing value in turn strengthens subsequent intake and food selection. Indeed, La Fleur and colleagues (la Fleur et al., 2007) found that when rats consumed a high caloric diet for a few weeks, the reinforcing value of this diet increased. In addition, rats displaying a higher reinforcing value for high-energy dense foods more easily gained weight when placed in an obesogenic environment. 


\section{DISGUSTING DURIANS AND CALORIC CONDITIONING}

One may conclude that high-energy dense foods are more reinforcing for overweight people and high restrained eaters. But how do foods become reinforcing? Food that one is unfamiliar with does not have any strong motivational appeal; who knows, it may not even be edible. A prominent example is the durian fruit that can be found in most marketplaces in Southeast Asia. Among western tourists the durian is famous for its foul smell and in most Southeast Asian hotels it is banned for precisely that reason. Despite its smell it is an exceptionally nutritious fruit ${ }^{3}$ and among the local Thai or Indonesian people, the durian is often referred to as the queen of all fruits. What is the basis for this marked intercultural difference in the reinforcing value of the durian fruit?

Experience with the durian is a prerequisite to come and appreciate its taste. In other words, learning is an important contributing factor in the incentive value of food, a process also known as incentive learning (Dickinson \& Balleine, 1990). One way to learn to appreciate food can be through flavour-nutrient learning (also known as caloric conditioning). Flavour-nutrient learning is a form of Pavlovian conditioning ${ }_{4}$ in which the flavour, smell and appearance of the food is associated with the positive post-ingestive effects of the food (Havermans, 2009). Consumption of foods high in calories results in satiation. This effect of satiation induces a positive shift in the preference for the food and research has demonstrated that this leads to increased consumption on later occasions (Yeomans, Leitch, Gould, \& Mobini, 2008). Note that although the reinforcing value of food is dependent on learning it does not exclude that there are innate differences in the sensitivity to the reinforcing value of food.

The study from chapter 4 showed that although self-reported liking for the fruit/vegetables option was similar to the self-reported liking for snacks, the overweight/obese participants worked harder for snacks compared to the normal weight

${ }_{3}^{3}$ The durian has an energy density of $\mathrm{I} 47 \mathrm{kcal} / \mathrm{I}$ oo $\mathrm{g}$, which is much more energy dense than the banana that has a density of $89 \mathrm{kcal} / \mathrm{I}$ oo $\mathrm{g}$.

${ }_{4}^{4}$ Pavlovian conditioning is a form of associative learning, named after the Russian scientist Ivan Pavlov. Pavlov (1927) demonstrated in one of his classical experiments with a dog that when food intake was preceded by the sound of a metronome for several times. The dog learned to associate the sound of the metronome with the food, and consequently started salivating by merely the presentation of the sound of the metronome. 


\section{CHAPTER 7}

participants. Liking is very much related to the flavour of food, but may just as well contribute to the reinforcing value of high-energy dense foods. Based on the findings from chapter 2 through 4 and flavour-nutrient learning experiments (Capaldi, I996; Havermans, 2009; Yeomans et al., 2008) one would, however, expect that the caloric density of the food makes it more reinforcing.

Whether high-energy dense foods are reinforcing because of the calories they contain or because of their taste qualities (flavour) could be tested by means of a concurrent schedules task with three alternative options (as in chapter 3). Participants would be individuals with a "sweet tooth" (i.e. people reporting and demonstrating a strong preference for sweet foods over savoury foods). The three food options consist of sweet high-energy dense snacks (e.g. chocolate); sweet low-energy dense foods (e.g. strawberries) and savoury high-energy dense snacks (e.g. crisps). The response requirement for earning points for sweet highenergy dense snacks would gradually increase and the alternatives remain at a steady reinforcement schedule with a low response requirement. In this way it can be determined which alternative is a better substitute for the high-energy dense sweet foods and thus which characteristic or aspect (sweet taste or caloric property) of the high-energy dense sweet food is more important for its reinforcing efficacy.

\section{PUBLIC POLICY MEASURES AND EXCESSIVE FOOD CONSUMPTION}

Regarding the findings of the first three studies that the relative reinforcing value of highenergy dense foods is higher for restrained eaters and overweight/obese people compared to normal weight controls and unrestrained eaters, one could suggest that these people need to learn to exercise more self-control, so that they do not give in to the temptation of highly palatable foods. What one could do is train inhibitory control to teach the restrained eater and overweight/obese person to withstand the impulse to eat (Guerrieri, Nederkoorn, Schrooten, Martijn, \& Jansen, 2009). This kind of research, though, is still in its infancy, and it is not entirely clear if such training is truly effective. But many roads lead to Rome, and maybe an alternative option to training internal self-control is by exerting external control. According to behavioural economic theory this can be done by increasing the costs for highenergy dense products. Results from the studies in chapters 5 and 6 suggest that a tax on high-energy dense products indeed may result in lower calorie consumption. It is also more effective than a subsidy on low-energy dense foods. It also suggests that such a tax on highenergy dense foods is more effective in reducing calorie consumption than providing calorie information (calorie labelling); that is, calorie labelling interfered with a tax when the 
target group was comprised of restrained eaters, suggesting that when these policy measures would be combined it could actually be counterproductive for restrained eaters. As this group of people is especially prone to overeat on high-energy dense foods, this would be an undesired effect.

In the study from chapter 6 a tax was predominantly effective in reducing calorie consumption in impulsive participants. However, since this is also a group that has been identified as being particularly sensitive to overconsumption of high-energy dense foods (Nederkoorn, Braet et al., 2006; Nederkoorn, Smulders et al., 2006) the finding that a highcalorie food tax especially affects food choice in these impulsive persons contributes to the notion that tax may actually be a beneficial public policy measure in curbing the obesity epidemic. A subsidy on low-energy dense foods encouraged low impulsive people to buy more low-energy dense foods. However, they did not compensate this increase in lowenergy dense foods by decreasing purchase of high-energy dense foods. For high impulsive people the subsidy actually backfired in that they bought more high-energy dense foods with the money they saved on buying low-energy dense foods. Altogether, results from these final two studies suggest that imposing a tax on unhealthy energy dense snack food is efficacious in affecting food choice and limiting caloric overindulgence.

\section{BENEFITS OF A BIG VERSUS SMALL TAX ON FATTENING FOODS}

The studies described above form an important first step in the direction of empirically validated policy measures to curb the obesity epidemic. However, there are still many questions to be answered. For instance, the studies reported in the present thesis employed a tax of 25 to 50 percent. Whether a substantially smaller (and politically more viable) tax would also be beneficial in limiting calorie consumption is yet to be examined. One could argue though that when it does not, the revenues from a small snack food tax might be employed to subsidize weight loss programs, to promote healthy diets through mass campaigns, and most importantly to fund experimental research aimed at understanding and tackling the obesity epidemic (Brownell et al., 2009). 


\section{CHAPTER 7}

\section{SUPERMARKET SCIENCE}

The present studies all simulated buying behaviour; a next step would be testing actual buying behaviour when a tax is implemented. This is not a very straightforward task to do, as few (if any) grocery stores will be inclined to increase the price of their high-energy dense products for an experimental study. However, it is not entirely impossible to test calorie buying behaviour in a more realistic setting. One way to jump the hurdle of unwilling grocery shops and supermarkets is by creating an own store. This may seem not very realistic, but one needs nothing more than an expanded version of the internet supermarket (Nederkoorn et al., 2009) as employed in chapter 6. One could thus easily have participants buy their groceries in an experimental internet supermarket. The experimenter then would have to purchase these groceries and deliver them at the participants' homes. This could be accomplished by means of the grocery delivery systems from local supermarkets. Participants then have to buy actual groceries with their own money and although one might argue that the online virtual shopping experience is fundamentally different from shopping in an actual store there is no reason to assume that people are less or more price sensitive consumers online than they are offline.

\section{WHY FREE WILL REQUIRES A FAIR CHOICE}

There are many other factors involved in the decision on whether or not to implement a policy such as a calorie-tax, apart from scientific evidence on the effectiveness of it. One may argue that food choice is everyone's personal responsibility and that governmental meddling into such a personal affair is undesirable. A counter argument is however that people do not eat with the express wish to become obese, but they eat energy dense foods because it is reinforcing. Many people tend to forget the longer term consequences of their behaviour if that behaviour is highly rewarding on a short term. Self regulatory failure is common and this does not necessarily reflect a person's general unwillingness to attain a healthy lifestyle or the choice to be obese. The frequently voiced dichotomy between free choice or no choice is false. Yes, many people choose to eat chocolate instead of strawberries (or nothing at all) but that is because the present environment makes the chocolate choice the easiest, least costly and most immediately rewarding choice. Governmental institutions can regulate this 
environment and directly contribute to making the healthy choice a relatively more attractive choice. One such regulatory measure may comprise taxing unhealthy foods and the studies presented in the current thesis provide a first glimpse into its potential effectiveness.

\section{CONCLUDING REMARKS}

The studies presented in this thesis provide evidence that overeating on high-energy dense foods is associated with a higher relative reinforcing value of these particular foods. When caught in this loop, it is hard to find the loophole; eating high-energy dense foods increases its reinforcing value and in its turn the increased reinforcing value stimulates eating the high-energy foods. Public policy makers might help. The current thesis provides direct evidence that a behavioural economic approach such as taxing high-energy dense foods is a promising attribution in curbing the obesity epidemic by decreasing the consumption of high-energy dense foods. 



\section{SUMMARY}

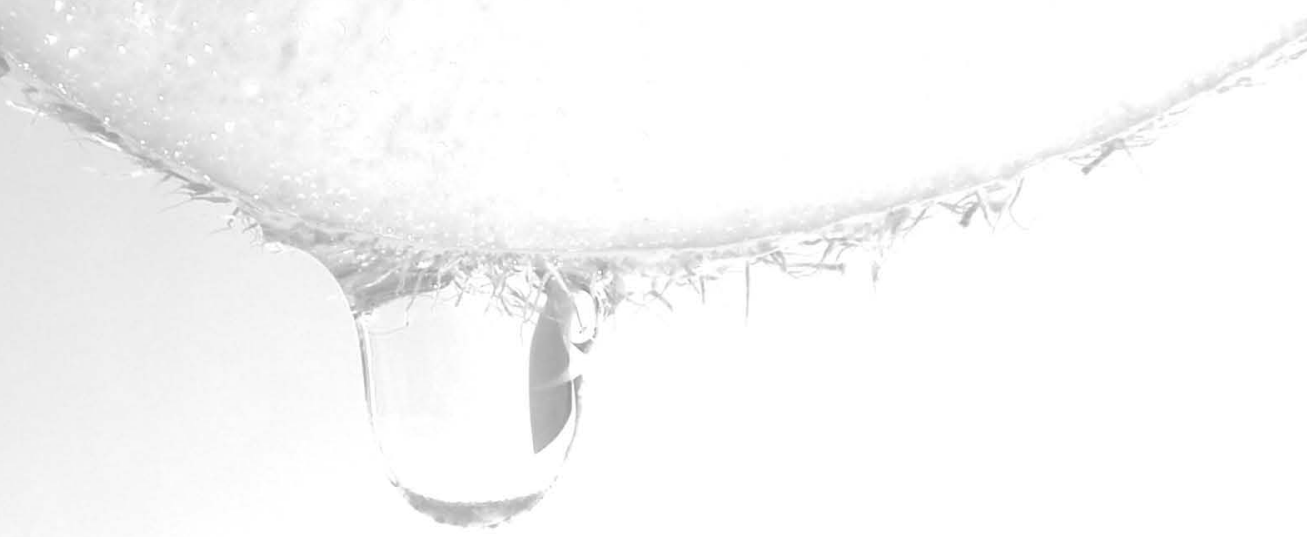




\section{SUMMARY}

Almost everybody enjoys eating, especially a snack once in a while. Food has a rewarding property; it is a primary reinforcer, strengthening nearly any behaviour that leads to it (Epstein \& Leddy, 2006). Why would that be? Well, food provides energy and energy is necessary for survival and thus it makes good functional sense that organisms such as humans have evolved to find food - especially energy dense foods - highly rewarding.

Nowadays food is abundant in the richer developed world, and already in many parts of the developing countries the environment provides a similarly rich variety in relatively cheap and palatable high-calorie snack food. It is therefore not surprising that worldwide the incidence of overweight and obesity is on the rise. Overweight and obesity are the result of a positive energy balance; that is, more energy is consumed than expended. To a large part, this positive energy balance can be explained by overconsumption, or in other words overeating (see e.g., Jéquier, 2002). Still, not everyone has become obese or overweight in this obesogenic environment; there seem to be individual differences in the vulnerability to overeating. Two groups of individuals known to be vulnerable to overeating are restrained eaters (see e.g., Herman \& Mack, 1975) - individuals who are concerned about their body weight and shape and, thus, try to restrict their food intake - and overweight/obese persons (Drewnowski, 1996). The reason, however, why restrained eaters and overweight/obese people particularly overeat on high-energy dense food is still largely unclear. Are highenergy dense foods more reinforcing for individuals with a tendency to overeat?

The first part of this thesis focuses on individual differences in the relative reinforcing value of high-energy dense foods. To measure the relative reinforcing value of high-energy dense foods a behavioural economic approach was used. That is, participants perform a concurrent schedules task in which they can choose to work for points representing two or more alternatives of which one is always a high-energy dense food. By progressively increasing the 'price' of the high-energy dense food (i.e., the amount of work required to obtain extra points for the food) it is possible to measure how hard someone is willing to work for the high-energy dense food in the presence of other alternatives available at a stable low 'price'. In other words, it is possible to measure how reinforcing the high-energy dense food is relative to the alternatives (e.g., fruit, or a fun activity that doesn't involve eating, or some money).

Trying to explain why restrained eaters often overeat on high-energy dense foods, the study described in chapter 2 tested if in comparison to unrestrained eaters and current dieters, non-dieting restrained eaters find snack foods more reinforcing. In a concurrent schedules task, the participants could work for high-energy dense snacks and fruit or vegetables. During the task, more and more effort was required to obtain the snack foods. It was found that non-dieting restrained eaters are willing to work harder to obtain snack foods compared to unrestrained eaters. Current dieters, however, do not work as hard for snacks compared to non-dieting restrained eaters and unrestrained eaters. The finding that 


\section{SUMMARY}

compared to unrestrained eaters, restrained eaters find snack foods more reinforcing was further extended in chapter 3. In this chapter it was found that more restrained participants also work harder for snacks compared to less restrained participants in the presence of even two alternatives (i.e., fruit/vegetables and sedentary activities). Furthermore, it was found that when the behavioural costs for snacks increase, both fruit/vegetables and sedentary activities are possible substitutes for snacks.

Research by Saelens and Epstein (I996) showed that relative to sedentary activities snack foods are more reinforcing for obese women than they are for normal-weight women. Because the alternatives in their task were non-food alternatives, the question remains if specifically high-energy dense food or food in general is more reinforcing for overweight/obese individuals than it is for normal-weight individuals. This question was investigated in the study presented in chapter 4. This study demonstrated that indeed specifically high-energy dense foods are more reinforcing for overweight/obese individuals and not just food in general. Overweight/obese persons were in comparison to normal weight persons willing to work harder for snacks on a concurrent schedules task with a highly liked snack and an equally liked fruit or vegetable as alternative.

The second part of this thesis comprises studies that focus on individual differences in response to policy measures aimed at decreasing energy consumption. According to behavioural economic theory unhealthy behaviour can be changed into healthier behaviour by altering the accompanying costs of the (un)healthy behaviour. In terms of food consumption this would be possible by either raising the prices for unhealthy high-energy dense foods, a so-called calorie tax, or by lowering the prices for low-energy dense foods, a subsidy. In chapter 5 , the combinatory effects of a calorie tax and providing calorie information (calorie labelling; a policy measure already implemented in some American cities, e.g., New York City) on lunch choice were studied in the light of individual differences in dietary restraint. Participants were presented with a menu (with or without calorie labelling) from which they had to choose a (hypothetical) lunch for three times on a row. With each time the prices for high-calorie foods were raised. Results indicate that an increase in costs associated with high-calorie foods reduces the number of calories bought for lunch, except for restrained eaters who also received calorie information.

Trait impulsivity has been associated with overeating and overweight/obesity (Guerrieri et al., 2007; Jansen et al., 2009; Nederkoorn, Braet et al., 2006). In chapter 6 it was investigated if high impulsive individuals are less responsive to a tax on high-energy dense food and a subsidy on low-energy dense food compared to low impulsive individuals. Contrary to the hypothesis it was demonstrated that high impulsive individuals decrease the number of calories they buy in response to a calorie tax, but increase the number of calories from high-energy dense products in response to a subsidy on low-energy dense food. In other words, the money saved on the purchase of subsidized low-energy dense products is 


\section{SUMMARY}

spent on high-energy dense products. The low impulsive individuals only seem to respond to a subsidy on low-energy dense products by increasing the amount of calories they buy from these products.

To recapitulate, the studies presented in the first part of this thesis support the hypothesis that the relative reinforcing value of high-energy dense food is higher for individuals vulnerable to overeating (i.e., restrained and overweight/obese individuals) in comparison to individuals without this vulnerability. Studies from the second part from this thesis demonstrate that a behavioural economic approach, that is increasing the costs for highenergy dense foods, seems to be a policy measure that might decrease excessive calorie consumption not just in people already concerned about their personal health but importantly also in individuals with a tendency to overeat. 


\section{SAMENVATTING}




\section{SAMENVATTING}

Praktisch iedereen geniet wel van eten, vooral die lekkere vette hap zo af en toe. Voedsel heeft een belonende eigenschap; het is een primaire bekrachtiger, dat wil zeggen dat het bijna alle gedrag versterkt dat tot het voedsel leidt (Epstein \& Leddy, 2006). Waarom zou dat zo zijn? Dat zit zo, voedsel levert energie en is dus noodzakelijk om te overleven. Vanuit een evolutionair oogpunt is het heel logisch en functioneel dat de mens voedsel - vooral energiedicht voedsel - erg belonend vindt.

Energierijk voedsel is alomtegenwoordig in onze westerse wereld, maar ook in ontwikkelingslanden is tegenwoordig vaak een vergelijkbaar groot aanbod van relatief goedkope smakelijke hoogcalorische snacks te vinden. Het is daarom ook niet verwonderlijk dat wereldwijd het aantal mensen met overgewicht en obesitas (extreem overgewicht) enorm toeneemt. Overgewicht en obesitas zijn het resultaat van een positieve energiebalans: er worden meer calorieën geconsumeerd dan verbruikt. Voor een groot gedeelte kan deze positieve energiebalans worden verklaard door overmatig consumeren, oftewel overeten (zie bijv., Jéquier, 2002). Toch krijgt niet iedereen overgewicht in deze obesogene omgeving; er blijken individuele verschillen te zijn in de gevoeligheid voor overeten. Twee groepen mensen waarvan bekend is dat ze vaker de neiging hebben tot overeten zijn (I) de zogenaamde 'restrained eaters' (zie bijv., Herman \& Mack, 1975) - mensen die zich zorgen maken over hun lichaamsgewicht en lichaamsvorm, en daarom graag gewicht zouden willen verliezen en dus vaker proberen hun voedselinname te beperken - en (2) individuen met overgewicht/obesitas (Drewnowski, 1996). Waarom 'restrained eaters' en mensen met overgewicht/obesitas te veel en te vaak energierijk voedsel eten, is goeddeels onbekend. Is energierijk voedsel misschien meer belonend/bekrachtigend voor mensen met een neiging tot overeten?

In het eerste gedeelte van dit proefschrift gaat de aandacht uit naar individuele verschillen in de relatieve bekrachtigende waarde van energierijk voedsel. Om dit te meten werd er gebruik gemaakt van een gedragseconomische aanpak. Dit houdt in dat deelnemers aan de verschillende studies een computertaak (concurrent schedules task) moesten uitvoeren waarin ze konden werken voor punten. Deze punten kon men inruilen voor een gegeven hoeveelheid van twee of meer alternatieven. Een van die alternatieven bestond altijd uit energierijk eten (bijvoorbeeld chocolade). Door geleidelijk de hoeveelheid werk die nodig is om een extra punt te verdienen voor het energierijke alternatief te verhogen (een 'prijs'verhoging als het ware), kan men meten hoezeer iemand bereid is te werken voor energierijk voedsel in de aanwezigheid van laagcalorische alternatieven die voor een vaste lage 'prijs' verkrijgbaar zijn. Met andere woorden, het is mogelijk om te meten hoe bekrachtigend/belonend de energierijke voeding is ten op zichte van de alternatieven (zoals fruit, of het spelen van een computerspelletje).

In een poging te verklaren waarom 'restrained eaters' overeten, werd in het onderzoek in hoofdstuk 2 getest of voor de niet lijnende 'restrained eaters' snacks meer bekrachtigend 


\section{SAMENVATTING}

zijn in vergelijking tot niet- 'restrained eaters' en mensen die juist wel een dieet volgen. Proefpersonen konden in de computertaak werken voor hoogcalorische snacks en voor fruit of groente. Gedurende de taak moest men steeds meer moeite doen om punten voor snacks te kunnen verdienen. Zoals verwacht waren de 'restrained eaters' bereid harder te werken voor snacks dan de niet- 'restrained eaters'. De proefpersonen die op dat moment een dieet volgden, werkten minder hard voor de snacks dan de 'restrained eaters' die geen dieet volgden en de niet-'restrained eaters'. De bevinding dat snacks een hogere bekrachtigende waarde hebben voor 'restrained eaters' dan voor niet-'restrained eaters' werd gerepliceerd in hoofdstuk 3. In de studie beschreven in dit hoofdstuk werd gevonden dat naar mate men meer 'restrained' is men ook harder werkt voor snacks, zelfs wanneer er twee alternatieven (namelijk fruit/groente en activiteiten) naast de snacks aangeboden werden. Daarnaast werd in deze studie ook gevonden dat wanneer de 'kosten' voor snacks omhoog gaan, zowel fruit/groente en weinig inspanning kostende activiteiten (zoals een tijdschriftje lezen of een spelletje spelen) als substituut voor snacks kunnen fungeren.

Onderzoek van Saelens en Epstein (1996) liet zien dat snacks meer bekrachtigend waren voor obese vrouwen dan voor vrouwen met een normaal gewicht. Deze proefpersonen werden ook onderworpen aan een concurrent schedules task waarbij de opties bestonden uit steeds 'duurder' wordende snacks tegenover stabiel 'goedkope' activiteiten. Heel mooi. Deze studie, hoe elegant ook, laat echter in het midden of voor obesen nu voedsel in het algemeen (doperwten, worteltjes, prei en zoal incluis) of snacks (zoals chocolade, koekjes, worstjes en chips) in het bijzonder extra bekrachtigend is. Deze vraag stond centraal in de studie beschreven in hoofdstuk 4. Zoals verwacht bleek specifiek energierijk voedsel meer bekrachtigend voor mensen met overgewicht/obesitas en niet zozeer voedsel in het algemeen. Proefpersonen met overgewicht/obesitas werden vergeleken met proefpersonen met een normaal gewicht. De proefpersonen met overgewicht waren bereid meer moeite te doen voor snacks in een taak waar ze konden werken voor een lekkere snack en even lekker gevonden stukjes fruit of groente.

Het tweede gedeelte van dit proefschrift betreft experimentele studies gericht op individuele verschillen in reactie op beleidsmaatregelen die als doel hebben overmatige consumptie van calorieën te beperken. Volgens gedragseconomische theorie kan ongezond gedrag worden omgevormd tot gezond(er) gedrag door de kosten van het (on)gezonde gedrag te veranderen. In het geval van voedselconsumptie is dit mogelijk door de prijzen van ongezond energierijk voedsel te verhogen met bijvoorbeeld een heffing op calorierijke producten (ook wel vettaks/calorietaks genoemd), of door de prijzen van gezonde laagcalorische voeding te verlagen met subsidie. In hoofdstuk 5 werd het gecombineerde effect van een calorietaks en het verschaffen van calorie-informatie (een beleidsmaatregel die al wordt toegepast in enkele Amerikaanse steden zoals New York) op het samenstellen van een lunch bestudeerd. Verder werd onderzocht of individuele hoog en laag 'restrained eaters' verschil- 


\section{SAMENVATTING}

lend reageren op deze prijsmaatregelen. Deelnemers aan de studie kregen een menukaart (met of zonder calorie-informatie) waarvan ze drie keer op rij een (hypothetische) lunch moesten samenstellen. Hiervoor kregen ze iedere keer een vast budget, maar voor elke lunch werden de prijzen van de hoogcalorische producten verhoogd. De resultaten laten zien dat deze prijsverhoging van hoogcalorische producten het totale aantal calorieën voor de samengestelde lunch doet dalen. Maar dit effect van een calorietaks trad niet op voor de 'restrained eaters' die ook calorie-informatie hadden gekregen. Zij leken bij de samenstelling van de lunch zich hoofdzakelijk te laten leiden door de calorische en niet de monetaire kosten van de lunchwaren.

Onderzoek heeft aangetoond dat impulsiviteit geassocieerd is met overeten en overgewicht/obesitas (Guerrieri et al., 2007; Jansen et al., 2009; Nederkoorn, Braet et al., 2006). In hoofdstuk 6 werd onderzocht of hoog impulsieve mensen minder ontvankelijk zijn voor een heffing op energierijk voedsel en een subsidie op laagcalorisch voedsel vergeleken met minder impulsieve mensen. In tegenstelling tot de verwachting liet het onderzoek zien dat hoog impulsieve mensen juist minder calorieën kopen in reactie op een heffing op energierijk voedsel, maar bij een subsidie op laagcalorisch voedsel kopen ze meer calorieën van energierijk voedsel. Met andere woorden, het geld dat wordt bespaard op gesubsidieerd laagcalorisch voedsel, wordt gebruikt voor de aanschaf van extra energierijk voedsel. De laag impulsieve mensen daarentegen lijken alleen ontvankelijk voor een subsidie op laagcalorische producten en kopen daar dan ook meer calorieën van.

Kortom, de studies uit het eerste gedeelte van dit proefschrift ondersteunen de hypothese dat de relatieve bekrachtigende waarde van energierijk voedsel hoger is voor mensen die gevoelig zijn voor overeten ('restrained eaters' en mensen met overgewicht/obesitas) vergeleken met mensen die daar niet gevoelig voor zijn. De studies uit het tweede gedeelte van dit proefschrift laten zien dat een gedragseconomische aanpak, dat wil zeggen de kosten van energierijk voedsel verhogen, een beleidsmaatregel kan zijn die het overmatig consumeren van calorieën kan beperken en niet alleen voor mensen die zich al zorgen maakten over hun gezondheid, maar juist ook voor mensen met een neiging tot overeten. 


\section{REFERENCES}




\section{REFERENCES}

Berridge, K. C. (1996). Food reward: Brain substrates of wanting and liking. Neuroscience \& Biobehavioral Reviews, 20, I-25.

Berridge, K. C. (2007). Brain reward systems for food incentives and hedonics in normal appetite and eating disorders. In T. C. Kirkham \& S. J. Cooper (Eds.), Progress in Brain Research: Appetite and Body Weight (pp. I9I-2I6). New York: Academic Press.

Brownell, K., Farley, T., Willett, W., Popkin, B., Chaloupka, F., Thompson, J., \& Ludwig, D. (2009). The public health and economic benefits of taxing sugar-sweetened beverages. The New England Journal of Medicine, 36I, I599-1605.

Burton, S., Creyer, E. H., Kees, J., \& Huggins, K. (2006). Attacking the obesity epidemic: the potential health benefits of providing nutrition information in restaurants. American Journal of Public Health, 96, I669-I675.

Capaldi, E. D. (I996). Conditioned food preferences. In E. D. Capaldi (Ed.), Why we eat what eat: The psychology of eating (pp. 53-8o). Washington, DC: American Psychological Association.

Caraher, M., \& Cowburn, G. (2005). Taxing food: implications for public health nutrition. Public Health Nutrition, 8, I242-I249.

Centraal Bureau voor de Statistiek. (2009). Zelfgerapporteerde medische consumptie, gezongheid en leefstijl [Self-reported medical consumption, health and lifestyle]. Available:

http://statline.cbs.nl/StatWeb/publication/?VW=T\&DM=SLNL\&PA $=03799 \& D I=24$ $2,254,267-270 \& D 2=0-2,4-7 \& D_{3}=0 \& D_{4}=0,5-8 \& H D=090527-$ I55I\&HDR $=$ G2,T\&STB $=$ GI,G3 [2010, February 8].

Dickinson, A., \& Balleine, B. (1990). Motivational control of instrumental performance following a shift from thirst to hunger. Quarterly Journal of Experimental Psychology Section B, 42, 4I3- 43I.

Drapeau, V., Provencher, V., Lemieux, S., \& Despres, J. (2003). Do 6-y changes in eating behaviors predict changes in body weight? Results from the Quebec Family Study. International Journal of Obesity, 27, 808-8I4.

Drewnowski, A. (1996). The behavioral phenotype in human obesity. In E. D. Capaldi (Ed.), Why we eat what we eat: The psychology of eating (pp. 29I-308). Washington, DC: American Psychological Association.

Drewnowski, A., Kurth, C., Holden-Wiltse, J., \& Saari, J. (1992). Food preferences in human obesity: Carbohydrates versus fats. Appetite, I8, 207-22I.

Epstein, L. H., Dearing, K. K., Roba, L. G., \& Finkelstein, E. (2010). The influence of taxes and subsidies on energy purchased in an experimental purchasing study. Psychological Science, 2I, 406-4I4. 
Epstein, L. H., Handley, E. A., Dearing, K. K., Cho, D. D., Roemmich, J. N., Paluch, R. A., Raja, S., Pak, Y., \& Spring, B. (2006). Purchases of food in youth. Influence of price and income. Psychological Science, I7, 82-89.

Epstein, L. H., \& Leddy, J. J. (2006). Food reinforcement. Appetite, 46, 22-25.

Epstein, L. H., \& Saelens, B. E. (200o). Behavioral economics of obesity: Food intake and energy expenditure. In W. K. Bickel \& R. E. Vuchinich (Eds.), Reframing Health Behavior Change With Behavioral Economics (pp. 293-3II). Mahwah: Lawrence Erlbaum Associates, Publishers.

Epstein, L. H., Truesdale, R., Wojcik, A., Paluch, R. A., \& Raynor, H. A. (2003). Effects of deprivation on hedonics and reinforcing value of food. Physiology and Behavior, 78, 2I2-227.

Ferster, C. B., \& Skinner, B. F. (1957). Schedules of Reinforcement. New York: AppletonCentury-Crofts.

Field, A. E., Coakley, E. H., Must, A., Spadano, J. L., Laird, N., Dietz, W. H., Rimm, E., \& Colditz, G. A. (200I). Impact of overweight on the risk of developing common chronic diseases during a Io-year period. Archives of Internal Medicine, I6I, I58I-I586.

Finkelstein, E. A., Ruhm, C. J., \& Kosa, K. M. (2005). Economic causes and consequences of obesity. Annual Review of Public Health, 26, 239-257.

Fishbach, A., \& Dhar, R. (2005). Goals as excuses or guides: The liberating effect of perceived goal progress on choice. Journal of Consumer Research, 32, 370-377.

French, S. A., Jeffery, R. W., Story, M., Breitlow, K. K., Baxter, J. S., Hannan, P., \& Snyder, M. P. (200I). Pricing and promotion effects on low-fat vending snack purchases: The CHIPS study. American Journal of Public Health, 9I, II2-II7.

Fujita, A., \& Sasabe, Y. (I986). Arkanoid [Computer game]. Tokyo: Taito Corporation.

Giesen, J. C. A. H., Havermans, R. C., Douven, A., Tekelenburg, M., \& Jansen, A. (20I0). Will work for snack food: The association of BMI and snack reinforcement. Obesity, I8, 966-970.

Giesen, J. C. A. H., Havermans, R. C., \& Jansen, A. (2010). Substituting snacks with strawberries and Sudokus: Does restraint matter? Health Psychology, 29, 222-226.

Giesen, J. C. A. H., Havermans, R. C., Nederkoorn, C., Strafaci, S., \& Jansen, A. (2009). Working harder to obtain more snack foods when wanting to eat less. Behaviour Research and Therapy, 47, I3-I7.

Giesen, J. C. A. H., Payne, C. R., Havermans, R. C., \& Jansen, A. (2010). Exploring how calorie information and taxes on high calorie foods influence lunch decisions. Manuscript submitted for publication.

Goldfield, G. S., \& Epstein, L. H. (2002). Can fruits and vegetables and activities substitute for snack foods? Health Psychology, 2I, 299-303. 


\section{REFERENCES}

Guerrieri, R., Nederkoorn, C., \& Jansen, A. (2007). How impulsiveness and variety influence food intake in a sample of healthy women. Appetite, 48, II9-I22.

Guerrieri, R., Nederkoorn, C., Schrooten, M., Martijn, C., \& Jansen, A. (2009). Inducing impulsivity leads high and low restrained eaters into overeating, whereas current dieters stick to their diet. Appetite, 53, 93-roo.

Harnack, L. J., \& French, S. A. (2008). Effect of point-of-purchase calorie labeling on restaurant and cafeteria food choices: A review of the literature. The International Journal of Behavioral Nutrition and Physical Activity, 5, 5I.

Havermans, R. C. (2009). Increasing children's liking and intake of vegetables through experiential learning. In R. R. Watson \& V. R. Preedy (Eds.), Bioactive Foods in Promoting Health: Fruits and Vegetables. San Diego: Elsevier.

Havermans, R. C., Janssen, T., Giesen, J. C. A. H., Roefs, A., \& Jansen, A. (2009). Food liking, food wanting, and sensory-specific satiety. Appetite, 52, 222-225.

Heatherton, T. F., Herman, C. P., Polivy, J., King, G. A., \& McGree, S. T. (I988). The (mis)measurement of restraint: An analysis of conceptual and psychometric issues. Journal of Abnormal Psychology, 97, 19-28.

Herman, C. P., \& Mack, D. (1975). Restrained and unrestrained eating. Journal of Personality, 43, 647-66o.

Herman, C. P., \& Polivy, J. (I980). Restrained eating. In A. J. Stunkard (Ed.), Obesity (pp. 208-225). Philadelphia: Saunders.

Herrnstein, R. J. (196I). Relative and absolute strenght of response as a function of frequency of reinforcement. Journal of the Experimental Analysis of Behavior, 4, 267272.

Herrnstein, R. J. (1970). On the law of effect. Journal of the Experimental Analysis of Behavior, 13, 243-266.

Heyman, G. M., Keith, G., \& Jason, G. (1999). Inelastic demand for alcohol in rats. Psychopharmacology, I44, 213-219.

Hill, C., Saxton, J., Webber, L., Blundell, J., \& Wardle, J. (2009). The relative reinforcing value of food predicts weight gain in a longitudinal study of 7-Io-y-old children. American Journal of Clinical Nutrition, 90, 276-28I.

Hill, C., Wardle, J., \& Cooke, L. (2009). Adiposity is not associated with children's reported liking for selected foods. Appetite, 52, 603-608.

Hursh, S. R. (1987). The economics of daily consumption controlling food - and water reinforced responding. Journal of the Experimental Analysis of Behavior, 29, 475-49I.

Hursh, S. R., \& Silberberg, A. (2008). Economic demand and essential value. Psychological Review, II5, I86-I98.

James, W. P. T. (2008). The epidemiology of obesity: the size of the problem. Journal of Internal Medicine, 263, 336-352. 
Jansen, A., Havermans, R., Nederkoorn, C., \& Roefs, A. (2008). Jolly fat or sad fat? Subtyping non-eating disordered overweight and obesity along an affect dimension. Appetite, 5I, 635-640.

Jansen, A., Nederkoorn, C., van Baak, L., Keirse, C., Guerrieri, R., \& Havermans, R. (2009). High-restrained eaters only overeat when they are also impulsive. Behaviour Research and Therapy, 47, I05-IIо.

Jansen, A., \& van den Hout, M. (I99I). On being led into temptation: "Counterregulation" of dieters after smelling a "preload". Addictive Behaviors, I6, 247-253.

Jeffery, R. W., Drewnowski, A., Epstein, L. H., Stunkard, A. J., Wilson, G. T., Wing, R. R., \& Hill, D. R. (2000). Long-term maintenance of weight loss: Current status. Health Psychology, I9(Suppl.), 5-I6.

Jéquier, E. (2002). Pathways to obesity. International Journal of Obesity, 26(Suppl.), I2-I7.

Johnson, M. W., \& Bickel, W. K. (2006). Replacing relative reinforcing efficacy with behavioral economic demand curves. Journal of the Experimental Analysis of Behavior, 85, 73-93.

Johnson, M. W., Bickel, W. K., \& Kirshenbaum, A. P. (2004). Substitutes for tobacco smoking: a behavioral economic analysis of nicotine gum, denicotinized cigarettes, and nicotine-containing cigarettes. Drug and Alcohol Dependence, 74, 253-264.

Kagel, J. H., \& Winkler, R. C. (I972). Behavioral economics: areas of cooperative research between economics and applied behavioral analysis. Journal of Applied Behavior Analysis, 5, 335-342.

Klesges, R. C., Isbell, T. R., \& Klesges, L. M. (1992). Relationship between dietary restraint, energy intake, physical activity, and body weight: A prospective analysis. Journal of Abnormal Psychology, IоI, 668-674.

la Fleur, S. E., Vanderschuren, L. J. M. J., Luijendijk, M. C., Kloeze, B. M., Tiesjema, B., \& Adan, R. A. H. (2007). A reciprocal interaction between food-motivated behavior and diet-induced obesity. International Journal of Obesity, 3I, I286-I294.

Lancaster, K. J. (I966). A new approach to consumer theory. The Journal of Political Economy, 47, I32-I57.

Lappalainen, R., \& Epstein, L. H. (I990). A behavioral economics analysis of food choice in humans. Appetite, I4, 8I-93.

Lea, S. E. G., Tarpy, R. M., \& Webley, P. (1987). The Individual in the Economy: A Survey of Economic Psychology. Cambridge, UK: Cambridge University Press.

Logan, G. D., Schachar, R., \& Tannock, R. (1997). Impulsivity and inhibitory control. Psychological Science, 8, 60-64.

Lowe, M. R. (1993). The effects of dieting on eating behavior: A three-factor model. Psychological Bulletin, II4, IOO-I2I. 


\section{REFERENCES}

Lowe, M. R. (1995). Restrained Eating and Dieting: Replication of their Divergent Effects on Eating Regulation. Appetite, 25, II5-II8.

Lowe, M. R., Annunziato, R. A., Markowitz, J. T., Didie, E., Bellace, D. L., Riddell, L., Maille, C., McKinney, S., \& Stice, E. (2006). Multiple types of dieting prospectively predict weight gain during the freshman year of college. Appetite, 47, 83-90.

Lowe, M. R., \& Timko, C. A. (2004). What a difference a diet makes: Towards an understanding of differences between restrained dieters and restrained nondieters. Eating Behaviors, 5, 199-208.

Lowe, M. R., Whitlow, J. W., \& Bellwoar, V. (I991). Eating regulation: The role of restraint, dieting, and weight. International Journal of Eating Disorders. Vol, Io, 46I-47I.

Madden, G. J. (2000). A behavioral economics primer. In W. K. Bickel \& R. E. Vuchinich (Eds.), Reframing Health Behavior Change With Behavioral Economics (pp. 3-26). Mahwh: Lawrence Erlbaum Associates, Publishers.

Mela, D. J. (2006). Eating for pleasure or just wanting to eat? Reconsidering sensory hedonic responses as a driver of obesity. Appetite, 47, I0-I7.

Must, A., Spadano, J., Coakley, E. H., Field, A. E., Colditz, G., \& Dietz, W. H. (I999). The disease burden associated with overweight and obesity. The Journal of the American Medical Association, 282, I523-I529.

Nederkoorn, C., Braet, C., Van Eijs, Y., Tanghe, A., \& Jansen, A. (2006). Why obese children cannot resist food: The role of impulsivity. Eating Behaviors, 7, 3I5-322.

Nederkoorn, C., Guerrieri, R., Havermans, R. C., Roefs, A., \& Jansen, A. (2009). The interactive effect of hunger and impulsivity on food intake and purchase in a virtual supermarket. International Journal of Obesity, 33, 905-912.

Nederkoorn, C., Smulders, F. T. Y., Havermans, R. C., Roefs, A., \& Jansen, A. (2006). Impulsivity in obese women. Appetite, 47, 253-256.

Nederkoorn, C., Van Eijs, Y., \& Jansen, A. (2004). Restrained eaters act on impulse. Personality and Individual Differences, 37, I-8.

Pavlov, I. P. (1927). Conditioned Reflexes: An Investigation of the Physiological Activity of the Cerebral Cortex (G. V. Anrep, Trans.). London: Oxford University Press.

Polivy, J. (1976). Perception of calories and regulation of intake in restrained and unrestrained subjects. Addictive Behaviors, I, 237-243.

Polivy, J., Herman, C. P., \& McFarlane, T. (1994). Effects of anxiety on eating: does palatability moderate distress-induced overeating in dieters? Journal of Abnormal Psychology, I03, 505-510.

Puhl, R., \& Brownell, K. (200I). Bias, discrimination and obesity. Obesity Research, 9, 788805 .

Raynor, H. A., \& Epstein, L. H. (2003). The relative-reinforcing value of food under differing levels of food deprivation and restriction. Appetite, 40, I5-24. 
Rissanen, A., Hakala, P., Lissner, L., Mattlar, C. E., Koskenvuo, M., \& Rönnemaa, T. (2002). Acquired preference especially for dietary fat and obesity: a study of weightdiscordant monozygotic twin pairs. International Journal of Obesity, 26, 973-977.

Roefs, A., \& Jansen, A. (2002). Implicit and xplicit attitudes toward high-fat foods in obesity. Journal of Abnormal Psychology, III, 5I7-52I.

Roefs, A., \& Jansen, A. (2004). The effect of information about fat content on food consumption in overweight/obese and lean people. Appetite, 43, 319-322.

Saelens, B. E., \& Epstein, L. H. (I996). Reinforcing value of food in obese and non-obese women. Appetite, 27, 4I-50.

Sarwer, D. B., \& Wadden, T. A. (1999). The treatment of obesity: What's new, what's recommended. Journal of Women's Health \& Gender-Based Medicine, 8, 483-493.

Schotte, D. E., Cools, J., \& McNally, R. J. (1990). Film-induced negative affect triggers overeating in restrained eaters. Journal of Abnormal Psychology, 99, 317-320.

Scott, K. M., Bruffaerts, R., Simon, G. E., Alonso, J., Angermeyer, M., de Girolamo, G., Demyttenaere, K., Gasquet, I., Haro, J. M., Karam, E., Kessler, R. C., Levinson, D., Medina Mora, M. E., Oakley Browne, M. A., Ormel, J., Villa, J. P., Uda, H., \& Von Korff, M. (2008). Obesity and mental disorders in the general population: results from the world mental health surveys. International Journal of Obesity, 32, I92-200.

Siep, N., Roefs, A., Roebroeck, A., Havermans, R., Bonte, M. L., \& Jansen, A. (2009). Hunger is the best spice: An fMRI study of the effects of attention, hunger and calorie content on food reward processing in the amygdala and orbitofrontal cortex. Behavioural Brain Research, I98, I49-I58.

Skinner, B. F. (1938). The behavior of organisms: An experimental analysis. New York: Appleton-Century-Crofts.

Smith, J. A., \& Epstein, L. H. (I99I). Behavioral economic analysis of food choice in obese children. Appetite, I7, 9I-95.

Solanto, M. V., Abikoff, H., Sonuga-Barke, E., Schachar, R., Logan, G. D., Wigal, T., Hechtman, L., Hinshaw, S., \& Turkel, E. (200I). The ecological validity of delay aversion and response inhibition as measures of impulsivity in AD/HD: A supplement to the NIMH multimodal treatment study of AD/HD. Journal of Abnormal Child Psychology, 29, 215-228.

Stice, E., Cameron, R. P., Killen, J. D., Hayward, C., \& Taylor, C. B. (1999). Naturalistic weight-reduction efforts prospectively predict growth in relative weight and onset of obesity among female adolescents. Journal of Consulting and Clinical Psychology, 67, 967-974.

Stice, E., Presnell, K., Shaw, H., \& Rohde, P. (2005). Psychological and behavioral risk factors for obesity onset in adolescent girls: A prospective study. Journal of Consulting and Clinical Psychology, 73, 195-202. 


\section{REFERENCES}

Swinburn, B. A., Sacks, G., Lo, S. K., Westerterp, K. R., Rush, E. C., Rosenbaum, M., Luke, A., Schoeller, D. A., DeLany, J. P., Butte, N. F., \& Ravussin, E. (2009). Estimating the changes in energy flux that characterize the rise in obesity prevalence. American Journal of Clinical Nutrition, 89, I723-I728.

Thorndike, E. L. (I9II). Animal Intelligence: Experimental Studies. New York: Macmillan.

Tillotson, J. E. (2004). America's obesity: conflicting public policies, industrial economic development, and unintended human consequences. Annual Review of Nutrition, 24, 6I7-643.

Urbszat, D., Herman, C. P., \& Polivy, J. (2002). Eat, drink, and be merry, for tomorrow we diet: effects of anticipated deprivation on food intake in restrained and unrestrained eaters. Journal of Abnormal Psychology, III, 396-40I.

Van Breukelen, G. J. P., \& Van Dijk, K. R. A. (2007). Use of covariates in randomized controlled trials. Journal of the International Neuropsychological Society, I3, 903-904.

Visscher, T. L., \& Seidell, J. C. (200I). The public health impact of obesity. Annual Review of Public Health, 22, 355-375.

Vuchinich, R. E., \& Tucker, J. A. (1983). Behavioral theories of choice as a framework for studying drinking behavior. Journal of Abnormal Psychology, 92, 408-4I6.

Werrij, M. Q., Mulkens, S., Hospers, H. J., \& Jansen, A. (2006). Overweight and obesity: the significance of a depressed mood. Patient Education and Counseling, 62, I26-I3I.

World Health Organization. (2006). Global database on Body Mass Index. Available: http://apps.who.int/bmi/index.jsp [2010, February 8].

Yeomans, M. R., Leitch, M., Gould, N. J., \& Mobini, S. (2008). Differential hedonic, sensory and behavioral changes associated with flavor-nutrient and flavor-flavor learning. Physiology \& Behavior, 93, 798-806. 


\section{DANKWOORD/WORD OF THANKS}




\section{DANKWOORD/WORD OF THANKS}

Het dankwoord is wellicht het meest gelezen onderdeel van een proefschrift. Het ironische daarbij is dat dit het enige onderdeel is dat ik volledig alleen heb moeten schrijven en dat dus niet meer is geperfectioneerd door mijn promotor of copromotor. Dit geeft wel direct aan dat de totstandkoming van mijn proefschrift niet een individuele 'tour de force' is geweest. Hierbij neem ik dan ook graag de gelegenheid om een aantal mensen te bedanken.

Anita, jij bent fantastisch! Ik had me geen betere promotor kunnen wensen. Je hebt me heel veel geleerd op het gebied van onderzoek en schrijven. Maar je hebt nog veel meer gedaan: je was niet alleen inhoudelijk een fantastische promotor, maar ook op persoonlijk vlak was je super en als het nodig was heb je zelfs voor me gevochten. En dat waardeer ik enorm. Het is geweldig om met jou te mogen samenwerken en ik ben dan ook heel blij dat ik dat de komende tijd nog steeds mag blijven doen. Dankjewel!

Remco, over mijn samenwerking met jou zou ik pagina's kunnen volschrijven, maar je weet dat ik dat niet zal doen. Ik hou nu eenmaal van kort en bondig $\odot$. Gedurende mijn project heb ik samen met jou veel tijd in de koffiehoek doorgebracht en dat geeft eigenlijk al direct aan wat een geweldige begeleider je bent. Ik heb ontzettend veel van je geleerd over schrijven (vooral dat het soms wat uitgebreider mag) en ik heb genoten van al onze discussies en spontane brainstormsessies over onderzoek, onder het genot van een kopje koffie. Remco, jij bent de beste leermeester die ik me kan bedenken en een geweldig persoon. Ik wil je bedanken voor je vertrouwen in mij en ik hoop dat we nog veel onderzoek samen zullen uitvoeren en koffie drinken natuurlijk. Dank!

Sjaan, als kamergenoot van Remco kon je mij onmogelijk ontwijken en het is dan ook niet verbazend dat jij substantieel hebt bijgedragen aan dit proefschrift. Bedankt voor al je wijze raad, fijne gesprekken en natuurlijk voor de gezellige pauzes in de koffiehoek.

Esther, jij was mijn eerste kamergenootje en door jou voelde ik me meteen helemaal op mijn plek. Ik heb een ontzettend leuke tijd met jouw gehad, en ik ben blij dat we nog steeds contact hebben. Je bent een ware vriendin voor mij geworden en ik ben er daarom trots op dat je mijn paranimf wil zijn. Dankjewel.

Katrijn, toen Esther wegging ben jij mijn nieuwe kamergenootje geworden en tegelijkertijd werd je door de eetgroep geadopteerd. Ondertussen ken ik je denk ik aardig goed en weet ik alles van je kat Ushi en hoe het met de bouw van je huis gaat. Ik kan altijd enorm met je lachen en soms om je lachen. Ik hoop dat we nog lang kamergenootjes zullen zijn, zodat ik mijn Vlaams vocabulaire verder kan uitbreiden. Ook van jou vind ik het erg tof dat jij mijn paranimf wil zijn. Dank. 
Anita, Carolien, Sandra, Sjaan, Anne, Remco, Jen, Katrijn, Hugo, Ramona, Esther, Elke, Nicolette, Astrid, Jessica, Nele en Harilaos, kortom de eetgroep. Het is altijd fijn om met jullie samen te werken en te discussiëren tijdens de eetgroepbijeenkomsten. Ik heb veel plezier gehad met jullie tijdens de vele etentjes en de verre congressen. Jullie zijn één voor één super collega's. Harilaos, it is your turn in our chess game. Nele, we hebben beide dezelfde dagelijkse begeleider voor ons AiO-project, bedankt voor je versterking. Astrid, jij was voor korte tijd mijn kamergenootje en Jessica, jij bent sinds kort mijn nieuwe kamergenootje: jullie zijn beide erg gezellige en toffe collega's, en het feit dat jullie beide tegen jullie computer praten heeft mij al veel lol opgeleverd. Sandra wij zijn dol op dezelfde muziek en schoenen, altijd reden voor een leuk gesprek. Hugo, bedankt voor je handige tips en hulp bij het maken van de cover van dit proefschrift. Nicolette, wij hadden dezelfde deadlines de afgelopen periode, het was fijn dat ik de stress met jou kon delen. Jen, Elke en Ramona bedankt voor de gezellige lunches. Jen, I had a fun time eating ice-creams in the summer. Elke, ik heb veel plezier gehad samen bij Zita Swoon. En Ramona, volgende keer nemen we wat langer de tijd om te shoppen in NYC. Anne, onder jouw begeleiding voerde ik mijn allereerste eetonderzoek uit en dat beviel mij zeer goed. Carolien ik vind het super om met jou samen te werken en 'Manipulation' te geven, bedankt dat ik deel uit mag maken van dit geweldige blok.

Fren en Martien, al vroeg tijdens mijn studie psychologie raakte ik enthousiast over wetenschap en experimenteel onderzoek, ik was vastbesloten dat ik ook onderzoeker wilde worden. Dit heb ik voornamelijk aan jullie passie voor het vak te danken en hiervoor ben ik jullie dan ook zeer dankbaar.

Voor de studies in dit proefschrift zijn heel wat proefpersonen getest. Gelukkig heb ik dit niet helemaal alleen hoeven te doen. Ik heb hierbij hulp gehad van Silvana, Anne en Mignon. Heel veel dank hiervoor!

Charlie en Michiel, hoe had de 'impulsieve supermarkt'-studie eruit gezien zonder jullie? Super bedankt voor de mooie stoptaak en de geweldig aangepaste supermarkt!

Jessie en Truus, jullie waren altijd op de meest vriendelijke manier bereid mij te helpen bij allerlei praktische zaken. Dank hiervoor.

Collega's van CPS, bedankt voor de leuke sfeer op de werkvloer.

Brian, thank you for letting me visit your Food \& Brand Lab and for giving me the opportunity to do research during my stay at Cornell. I learned a lot and had great fun. 


\section{DANKWOORD/WORD OF THANKS}

Collin, it was a great pleasure sharing the office with you. I very much enjoyed discussing research with you and in the end conducting a study together. You are always very quick in responding and I learned a lot from your detailed feedback on my writing. I also want to thank you and your family for taking me to the fantastic Ivy League Cornell - Harvard basketball game ...go BIG RED!!

Everyone from the Food \& Brand Lab, thank you for the fun time and for helping me out whenever I needed help with something.

Karen, thank you for your hospitality, for all the fun chats in the evenings, for making maple syrup together, and going to the farmers' market. Thank you for showing me all the beautiful waterfalls in the neighbourhood and of course for taking Sjir and me on a trip along the Erie Canal. You made my stay in Ithaca wonderful!.

Tswakai, you were a fantastic housemate, I enjoyed our many conversations in the kitchen during cooking. And thank you, for the late-night grocery shopping. How would I have gotten to a supermarket without you?

Lieve vrienden en familie, velen van jullie hebben mij wel vaker gevraagd hoe het nu vorderde met mijn boekje. Nu, jullie zien het: het is af! Jullie hebben weliswaar niet direct bijgedragen aan die totstandkoming van dit boekje, maar jullie hebben mijn leven wel buitengewoon leuker, plezieriger en aangenaam gemaakt. Bedankt voor alle gezellige kampvuurfeestjes, etentjes, schaaktrainingen, schaakpotjes, avonden stappen en vooral de leuke gesprekken. Jullie zijn top!

Yonneponne, jou ken ik al vanaf dat wij een jaar of acht waren. We zaten samen op schaken en sinds die tijd hebben we feitelijk hetzelfde pad bewandeld. Vanaf de brugklas tot en met het eindexamenjaar hebben we naast elkaar in de klas gezeten. Daarna hebben we voor korte tijd voor een andere universiteit gekozen, maar het heeft niet lang geduurd totdat we weer samen psychologie studeerden. Mijn AiO-tijd was eigenlijk de eerste periode sinds ik jou heb leren kennen dat we elkaar niet wekelijks of zelfs dagelijks zagen. Het was dan ook wel even afkicken. Gelukkig werkt vriendschap ook prima op een afstand (nu heb ik ook nog een leuk vakantieadres in Noorwegen erbij). Yonne ik wil je bedanken voor je onvoorwaardelijke vriendschap, jij bent en blijft mijn beste vriendin.

Mieke, ik vind het spijtig dat Lud dit alles niet meer meemaakt. Jullie zijn beide altijd erg enthousiast over en betrokken geweest bij mijn promotie-traject en dat heb ik altijd zeer gewaardeerd. Bedankt. 
Mam en Pap, ik zou niet weten waar te beginnen. Er is zoveel waarvoor ik jullie dankbaar ben. In ieder geval wil ik jullie bedanken voor jullie liefde, oneindig vertrouwen en het feit dat jullie altijd voor mij klaar staan. Dankjewel.

Sjir, jij bent mijn maatje. Met jou kan ik over alles praten en dus ook over mijn onderzoek en dat vind ik geweldig. Bedankt voor je optimisme, relativeringsvermogen, vriendschap en zoveel meer. Bedankt voor alles. Jij maakt mijn leven compleet. 



\section{Curriculum Vitae}

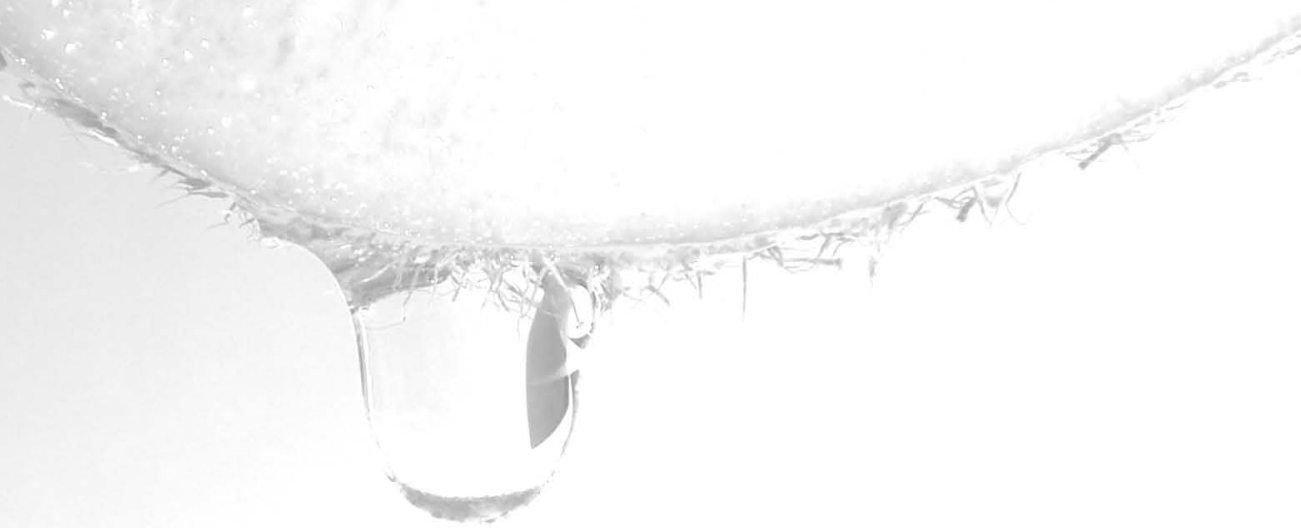




\section{CurRiculum Vitae}

Janneke Christina Antonius Hubertina Giesen was born on November 24, 1982, in Brunssum, the Netherlands. In 20oI she graduated from secondary school, Atheneum, St. Janscollege in Hoensbroek. After that, she studied Innovation Sciences at Eindhoven University of Technology and in January 2003 she started studying Psychology at Maastricht University. In July 2005 she received her bachelor's degree in psychology and in August 2006 she graduated and received her master's degree in applied cognitive psychology (cum laude). Immediately after graduation she started her $\mathrm{PhD}$ project at the Department of Experimental Psychology at Maastricht University. Part of the research for this project she conducted at the Food and Brand Lab, Cornell University. Since April 2010 she is a postdoctoral fellow at the Department of Clinical Psychological Science (formerly the Department of Experimental Psychology). 


\section{CurRiculum VitaE}

\section{Publications}

Giesen, J.C.A.H., Havermans, R.C., Douven, A., Tekelenburg, M., \& Jansen, A. (2010). Will work for snack food: The association of BMI and snack reinforcement. Obesity, I8, 966970.

Giesen, J.C.A.H., Havermans, R.C., \& Jansen, A. (2010). Substituting snacks with strawberries and Sudokus: Does restraint matter? Health Psychology, 29, 222-226.

Giesen, J.C.A.H., Havermans, R.C., Nederkoorn, C., Strafaci, S., \& Jansen, A. (2009). Working harder to obtain more snack foods when wanting to eat less. Behaviour Research and Therapy, 47, I3-I7.

Giesen, J.C.A.H., Havermans, R. C., \& Jansen, A. (2008). (On)gezond leven is een keuze: een gedragseconomische analyse van de homo (on)economicus. [(Un)healthy behaviour is a choice: A behavioural economic analysis] De Psycholoog, 43, 613-618.

Havermans, R.C., Janssen, T., Giesen, J.C.A.H., Roefs, A., \& Jansen, A. (2009). Food liking, food wanting, and sensory-specific satiety. Appetite, 52, 222-225.

\section{Manuscripts submitted for publication}

Giesen, J.C.A.H., Payne, C.R., Havermans, R.C., \& Jansen A. (2010). Exploring how calorie information and taxes on high calorie foods influence lunch decisions.

Giesen, J.C.A.H., Havermans, R.C., Nederkoorn, C., \& Jansen A. (2010). Impulsivity in the supermarket: Responses to calorie taxes and subsidies.

Nederkoorn, C., Havermans, R.C., Giesen, J.C.A.H., \& Jansen, A. (2010). High tax on high energy dense foods and its effects on the purchase of calories in a supermarket: An experiment.

Roefs, A., Smulders, F.T.Y., Schoenmakers, T., Wiers, R., Schrooten, M., Kessels, L., \& Giesen, J.C.A.H. (2010). The influence of primes on affect judgement can be avoided.

\section{Conference presentations}

Giesen, J.C.A.H., Havermans, R.C., Jansen, A. (20I0). Developing evidence based policy for preventing obesity: The influence of calorie information and a calorie tax on buying lunch. Paper presented at the 6th World Congress of Behavioral \& Cognitive Therapies. Boston, United States of America. 


\section{CurRiculum Vitae}

Giesen, J.C.A.H., Havermans, R.C. Nederkoorn, C., \& Jansen, A. (2010). Consumer behavior influenced by taxing high-energy dense products and subsidizing low-energy dense products: The role of impulsivity. Paper presented at the annual meeting of the British Feeding and Drinking Group. Maastricht, The Netherlands.

Giesen, J.C.A.H., Wansink, B., Payne, C.R., Havermans, R.C., \& Jansen, A. (2009). Preventing obesity: The influence of calorie information and a calorie-tax on buying lunch . Poster presented at the isth annual meeting of the "Eating Disorders Research Society". New York, United States of America.

Giesen, J.C.A.H., Havermans, R.C., \& Jansen, A. (2009). Reinforced with snacks: BMI makes the difference. Paper presented at the annual meeting of the British Feeding and Drinking Group. Swansea, England

Giesen, J.C.A.H., Havermans, R.C., Nederkoorn, C., Strafaci, S., \& Jansen, A. (2007). Working for snack-food: The role of dietary restraint. Poster presented at the I3th annual meeting of the "Eating Disorders Research Society". Pittsburgh, United States of America.

Giesen, J.C.A.H., Havermans, R.C. Nederkoorn, C., Strafaci, S., \& Jansen, A. (2007). Working for snack-food: The role of dietary restraint. Paper presented at the V World Congress of Behavioural \& Cognitive Therapies. Barcelona, Spain.

Giesen, J.C.A.H., Havermans, R.C., Nederkoorn, C., Strafaci, S., \& Jansen, A. (2007). Working for snack-food: The role of dietary restraint. Paper presented at the annual meeting of the British Feeding and Drinking Group. Newcastle, England. 


